\title{
RENATO MARTINS
}

Implantes de zircônia reforçada com ítria (Y-TZP).

Avaliação histomorfométrica

\section{BAURU}





\section{RENATO MARTINS}

\section{Implantes de zircônia reforçada com ítria (Y-TZP). Avaliação histomorfométrica}

Tese apresentada à Faculdade de Odontologia de Bauru da Universidade de São Paulo como parte dos requisitos necessários para a obtenção do título de DOUTORADO em Ciências Odontológicas Aplicadas, na área de concentração Estomatologia e Biologia Oral

Versão corrigida

Orientador: Prof. Dr. Rodrigo Cardoso de Oliveira

Versão Corrigida

\section{BAURU}




\section{Martins, Renato}

M365i Implantes de zircônia reforçada com ítria (Y-TZP). Avaliação histomorfométrica / Renato Martins. -- Bauru, 2013.

159 p. : il. ; $31 \mathrm{~cm}$.

Tese. (Doutorado) -- Faculdade de Odontologia de Bauru. Universidade de São Paulo.

Orientador: Prof. Dr. Rodrigo Cardoso de Oliveira

Nota: A versão original desta tese encontra-se disponível no Serviço de Biblioteca e Documentação da Faculdade de Odontologia de Bauru - FOB/USP.

Autorizo, exclusivamente para fins acadêmicos e científicos, a reprodução total ou parcial desta dissertação, por processos fotocopiadores e outros meios eletrônicos.

Assinatura:

Data

Comitê de Ética da FOB-USP

Protocolo número: CEEPA 006/2010

Data: 04 de Maio de 2010 


\section{DEDICATÓRIA}

Primeiramente à Deus, pela saúde e pelas pessoas que colocou e ainda vai colocar em meu caminho.

À minha família, Roberto Martins (Pai), Beti de Oliveira Martins (Mãe), Mônica de Oliveira Martins (Irmã) e Roberto Martins Junior (Irmão), pelo amor incondicional e pelo exemplo de retidão e honestidade. Tenho orgulho de fazer parte dessa família!

À minha tia Maria Helena Martins que sempre me ajudou e apoiou desde as fases iniciais do meu aprendizado

À minha esposa Francini Paludeto por sua colaboração, compreensão, paciência e incentivo nesta jornada. Sem o seu auxílio a concretização deste trabalho seria impossível, às nossas filhas Maria Luiza Paludeto Martins e Flora Paludeto Martins que, de maneira inocente, tiveram de dispor de vários momentos de lazer e alegria junto a mim, para que eu pudesse realizar este estudo. Vocês são o meu tesouro!, AMO VOCÊS!

Aos meus sogros Jair Paludeto e Marilsa Leão Paludeto pelo apoio e incentivo, principalmente no tempo que passaram com as netas em função da minha ausência por conta dos compromissos que este estudo exigiu. Muito obrigado! 



\section{AGRADECIMENTOS}

Agradeço a Deus pelo dom da vida e por estar sempre ao meu lado, por me mostrar que as coisas não são sempre do jeito que imagino, devendo esperar o Seu tempo, não o meu. Por derramar tantas bênçãos em nossas vidas, por renovar o nosso espírito e por lapidar nosso coração. Acredito que o sofrimento nos faz crescer, hoje sei que sou um ser humano melhor e quero continuar aprendendo.

Ao meu orientador, Prof. Dr. Rodrigo Cardoso de Oliveira, pela confiança, dedicação, paciência e sabedoria com que soube conduzir-me nesta etapa da minha vida. Deixo aqui todo meu respeito e gratidão pelos ensinamentos ao longo destes anos. MUITO OBRIGADO por me conceder a honra de ser seu orientado e possibilitar alcançar meus objetivos. Tenho muito orgulho de dizer que fui orientado por um profissional tão competente.

A minha "co-orientadora", Dra. Tânia Mary Cestari, pela estimável amizade, competência e pela generosidade ao longo deste trabalho. Agradeço sua confiança, todas as oportunidades e ensinamentos que muito engrandeceram minha formação, assim como as orientações com conversas sempre esclarecedoras, achando soluções e simplificando os problemas. Sempre lhe terei eterna gratidão $e$ admiração tanto como pessoa quanto por seu grande exemplo como profissional, que realmente gosta do que faz, sempre ocupada, mas ao mesmo tempo disponível, conciliando inúmeras coisas ao mesmo tempo. Obrigado por me acolher, me ensinar e demonstrar a arte em fazer ciência.

Ao Prof. Dr. Marcelo José Carbonari, doutor em Ciências e Tecnologia Nuclear (Instituto de Pesquisas Energéticas Nucleares -IPEN), que me incentivou nessa jornada, se colocando sempre a disposição e tornando-se um AMIGO, no sentido mais aplo da palavra. 

Ao Laboratório de Bioquímica, aos professores Dra. Marília Afonso Rabelo Buzalaf e Dra. Ana Carolina Magalhães e aos funcionários Telma Lopes Silva, Larissa Tercilia Grizzo e Aline Leite, pela acolhida e todo suporte prestado.

Ao Prof. Dr. Rumio Taga que me abiu as portas do laboratório de Histologia, pela acolhida e convívio agradável no departamento e nas várias reuniões informais que nos proporcionou em sua residência.

A Faculdade de Odontologia de Bauru e aos professores que me possibilitaram aprender e a crescer profissional e pessoalmente.

A secretária Vera Cruz Rufino pela dedicação, empenho e disposição que sempre demonstrou em todo decorrer deste trabalho.

Ao Laboratório Histologia, por me ensinar que competência e alegria podem caminhar juntos. Em especial aos amigos e amigas, Aldivina Alves, Andréa Spinolla, Gabriela Genaro, Elcia V. Silveira, Paula S. Dos Santos, Daniela S. Pereira, Bruna B. Bigueti, Ricardo Vinicius Nunes Arantes, Reinaldo Germino, Tamiris Vallin, Caroline Rocha, Teresa Silva e Carlos Eduardo Repeke pela amizade, momentos de risada e descontração.

Aos coelhos que deram suas vidas para que outras vidas sejam salvas

As amigas, Daniele Ceolin e Patrícia Mortágua por se fazerem sempre presente, participarem integralmente desse trabalho e pelos incentivos constantes, principalmente nos momentos difíceis.

Aos funcionários do Centro Integrado de Pesquisas - CIP, Márcia Sirlene Zardin Graeff, Marcelo Melanda Ribeiro Lopes e Renato Pereira Murback por todo apoio e suporte para que os trabalhos, apesar das adversidades enfrentadas, fossem realizados. 

Ao biotério da Faculdade de Medicina da UNESP de Botucatu, por terem fornecidos os animais utilizados nesta pesquisa.

À Coordenação de Aperfeiçoamento de Pessoal de Nível Superior (CAPES), pela bolsa de estudos concedida.

A todos enfim que colaboraram direta ou indiretamente para a realização deste trabalho e ao longo do meu doutorado, MUITO OBRIGADO!, vocês têm minhas orações. 

"O degrau de uma escada nãa serue simplesmente para que alguém permaneça em cima dele. destina-se a sustentar a pé de un homem pela tempa suficiente para que ele coloque a outra um panca mais alta.

Thomas Huxley 



\section{RESUMO}

O objetivo do trabalho foi avaliar "in vivo" a osseointegração de implantes produzidos em zircônia reforçada com ítria (Y-TZP) e compará-los com o implante de titânio usinado e com o de superfície jateada com brushita. Para tanto, nas tíbias de 20 coelhos machos $(n=10)$ e fêmeas $(n=10)$ foram implantadas em uma das tíbias 0 implante Y-TZP (GE-1, n=10 implantes) e na outra tíbia o titânio usinado (GC, $n=5$ implantes) ou jateado com brushita (GE-2, $n=5$ implantes). Os animais receberam marcadores ósseos fluorescentes, tetraciclina (14 e 21 dias), alizarina (28 e 35 dias) e calceína (42 e 49 dias) após a cirurgia de implantação. Ao final de 56 dias, a região dos implantes foi coletada e processada histologicamente para obtenção de cortes teciduais não desmineralizados. Nas imagens obtidas no microscópio confocal foi avaliado o percentual de área para cada marcador. Nos cortes corados pelo azul de toluidina foi avaliado morfologicamente a qualidade do tecido ósseo formado e a existência de interposição de tecido conjuntivo entre osso e implante, e morfometricamente determinado o percentual de contato osso-implante (BIC) e o percentual de tecido ósseo próximo à superfície do implante (BA). Os resultados mostraram que, não houve diferenças estatisticamente significantes entre machos e fêmeas quanto aos parâmetros avaliados. Com relação aos grupos, GE-1 e GC apresentaram cortical óssea remanescente íntegra e formação de um tecido ósseo maduro/lamelar na superfície dos implantes. No GE-2 ocorreu intensa reabsorção da cortical óssea pre-existente próxima ao implante e extensa formação óssea mais imatura em relação aos observados no GE-1 e GC. Essa intensa reabsorção e extensa formação óssea fez com que o percentual de área dos marcadores fluorescentes fosse em média 0,73 vezes maior no GE-2 em relação aos grupos GE1 e GC. Com relação ao BIC não houve diferença entre os grupos, sendo em média de $47,8 \%$, porém, o BA no grupo GC $(66,2 \%)$ foi 0,33 vezes maior em relação ao GE-1(51,6\%) e GE-2 (48,2\%). No modelo utilizado o implante Y-TZP apresentou osseointegração similar ao titânio usinado e superior ao jateada com brushita, podendo ser considerado uma alternativa para substituir o implante titânio quando a estética esta envolvida.

Palavras chaves: Implantação dentária endo-óssea. Cerâmica. Tíbia. Coelhos. Osseointegração 



\section{ABSTRACT \\ Y-TZP dental implants. Histomorfometry analysis}

The aim of this work was evaluate "in vivo" the osseointegration of implants produced with yttria stabilized zirconia (Y-TZP) and compare it with machined titanium implant and sandblasted surface with brushita titanium. Therefore, on the tibia of 20 rabbits males $(n=10)$ and female $(n=10)$ were implanted in one of the tibias the implant Y-TZP (GE-1, $n=10$ implants) and on the other tibia the machined titanium (GC, $n=5$ implants) or sandblasted surface with brushita titanium (GE-2, n=5 implants). The animals received fluorescent bone markers, tetracycline (14th and 21 th days), alizarin (28th and 35th days) and calcein (42th and 49th days). At the end of 56 days, the implants regions were collected and histomorphometrically processed to obtain tissue sections not demineralized. On images obtained from confocal microscopy was evaluated the percentage of area for each bone markers. On slides stained with toluidine blue was measured morphologically the quality of formed bone tissue and the existence of interposition of connective tissue between bone and implant, and was morphometrically determined the percentage of bone-implant contact (BIC) and the percentage of bone tissue next to the implant surface (BA). The results showed that there were no statistically significant differences between male and female regarding to evaluated parameters. Concerning to the groups, GE-1 and GC exhibited wholesome remaining cortical bone and formation of mature/lamellar bone tissue on implants surface. In GE-2 ocurred intense reabsorption of preexisting cortical bone next to the implant and extensive bone formation more immature than GE-1 and GC. This intense reabsorption and extensive bone formation made the GE-2 area percentage for fluorescent markers 0.73 times higher on average when compared to GE- 1 and GC. About the BIC, there were no differences between the groups, with an average of $47.8 \%$, however, the BA on GC group (66.2\%) was 0.33 higher compared to GE-1 (51.6\%) and GE-2 (48.2\%). In the model used, the Y-TZP implant exhibited osseointegration suchlike machined titanium and better than sandblasted surface with brushita titanium, being considered an alternative to replace the titanium implant when aesthetics is involved.

Keywords: Endosseous dental implantation. Ceramics. Tibia. Habbits. Osseointegration 



\section{LISTA DE ABREVIATURAS E SIGLAS}

$\begin{array}{ll}\sim & \text { Aproximadamente } \\ { }^{\circ} \mathrm{C} & \text { Grau Celsius (centígrado) } \\ \mu \mathrm{m} & \text { Micrometro (10-6 metros) } \\ 3 \mathrm{Al}_{2} \mathrm{O}_{3} .2 \mathrm{SiO}_{2} & \text { Mulita } \\ 3 \mathrm{Y}-\mathrm{TZP} & \text { Zircônia Estabilizada com ítria 3\% mol } \\ \mathrm{Al}_{2} \mathrm{O}_{3} & \text { óxido de alumínio, alumínia amorfa } \\ \mathrm{Al}_{2} \mathrm{O}_{3}-\mathrm{ZrO} 2 & \text { Cerâmica de Zircônia alúmina } \\ \mathrm{AMES} & \text { Teste para detecção de citotoxidade e mutagenicidade causadas } \\ & \text { por metais pesados e radicais livres } \\ \mathrm{ANOVA} & \text { Análise de variância } \\ \mathrm{BIC} & \text { Percentual de contato osso-implante (Bone-Implant Contact) } \\ \mathrm{BMP} & \text { Proteína morfogenética óssea } \\ \mathrm{C}-\mathrm{T} & \text { Fase cúbica para a fase tetragonal } \\ \mathrm{CaO} & \text { Óxido de cálcio } \\ \mathrm{CaP} & \text { Cálcio bioativo reabsorvível } \\ \mathrm{Ca}-\mathrm{PSZ} & \text { Zircônia Parcialmente Estabilizada com Cálcio } \\ \mathrm{CEEPA} & \text { Comissão de Ética no Ensino de Pesquisa em Animais } \\ \mathrm{CeO} & \text { Céria } \\ \mathrm{CeO} & \text { Óxido de cério } \\ \mathrm{Cm} & \text { Centímetro } \\ \mathrm{Cm}{ }^{2} & \text { Centímetro Quadrado } \\ \mathrm{Coelhos} \mathrm{NZW} & \text { Coelhos da raça New Zealand } \\ \mathrm{Fase} \mathrm{C} & \text { Fase cúbica } \\ \mathrm{Fase} \mathrm{M} & \text { Fase monocíclica } \\ \mathrm{Fases} \mathrm{T} & \text { Fase tetragonal } \\ \mathrm{FTIR} & \text { Expectroscopia de radiação infravermelha (Fourier transform } \\ \mathrm{GC} & \text { infrared spectroscopy) } \\ & \text { Grupo Controle - Titânio usinado } \\ & \end{array}$



GE-1

GE-2

$\mathrm{GPa}$

$\mathrm{H}$

HA/HAP

HIP

HUVEC

ICZ

ISSO

kcal mol-1

$\mathrm{Kg}$

LD

Log kJ mol-1

LTD / AGING

$\mathrm{M}$

MEV

Mf

$\mathrm{Mg}$

$\mathrm{MgO}$

Mg-PSZ

$\mathrm{Mi}$

MI

$\mathrm{Mm}$

Módulo

Young

$\mathrm{MPa}$

MPa.m $\mathrm{m}^{0,5}$

MTT
Grupo Experimental 1 - Implante de Y-TZP

Grupo Experimental 2 - Titânio jateado com brushita

Gigapascal $\left(10^{9}\right)$

Horas

Hidroxiapatita

Processo de pós-compactação Isostático

Células Endoteliais da Veia Umbilical Humana

Alumina infiltrada por vidro reforçada por zircônia (zirconiareinforced glass-infiltrated alumina)

Organização Internacional para Padronização (International Organization for Standardization)

Quilocaloria por mol

Kilogramas

Dose Letal - pag. 49

Logaritmo de quilojoule por mol

Degradação à baixa temperatura - envelhecimento

Mol

Microscopia eletrônica de varredura

Massa corporal 8 semanas após cirurgia

Miligrama

Óxido de magnésio

Zircônia parcialmente estabilizada com óxido de magnésia

Massa corporal no dia da cirugia

Mililitro

Milímetros

de Parâmetro mecânico que proporciona uma medida da rigidez de um material sólido

Mega pascal $\left(10^{6}\right)$

Mega pascal aplicado ao metro quadrado

Teste de viabilidade celular 

N

$\mathrm{NaHCO}_{3}$

PECF

$\mathrm{PHA}$

PPF

Ppm

PSZ

$\mathrm{SiO}_{2}$

SLA

TCP

THR

Ti-6Al-4V

$\mathrm{TiO}_{2}$

T-M

TZP

UHMWPE

$\mathrm{UO}_{2}$

$\mathrm{X}$

$\mathrm{Y}_{2} \mathrm{O}_{3}$

Y-PSZ

Y-PSZ

Y-TZP

$\mathrm{Zn}-\mathrm{Y}$

$\mathrm{Zr}(\mathrm{OH})_{4}$

$\mathrm{Zrl}_{4}$

$\mathrm{ZrO}_{2}$

$\mathrm{ZrO}_{2}$
Newton

Bicarbonato de sódio

Fluido Pseudo Extra Celular

Polihidroxialcanoatos

Prótese parcial fixa

Parte por milhão

Zircônia parcialmente estabilizada

Óxido de Silício

Jateadas com areia e tratadas com ácido (acid-etched sandblasting)

Fosfato Tricálcico

Artroplastias totais do quadril (total hip replacement)

Liga de titânio

Dióxido de Titânio

Transformação da fase tetragonal para a fase monocíclica

Zircônia Tetragonal Policristalina (tetragonal zirconia polycrystal)

Polietileno de Ultra Alto Peso Molecular (Ultra high molecular weight polyethylene)

Dióxido de Uránio

Vezes

Óxido de ítrio

Zircônia parcialmente estabilizada com ítrio

Zircônia parcialmente estabilizada com ítrio

Zircônia reforçada com ítria (Yttria Stabilized Zirconia)

Zircônia-Itria

Hidróxido de Zircônio

lodeto de zircônio IV (Zirconium(IV) iodide)

Óxido de Zircônia

Zircônia ou óxido de zircônio, badeleita 

$\mathrm{ZrO}_{2}-\mathrm{Y}_{2} \mathrm{O}_{3} \quad$ óxido de Zircônia - óxido de ítrio

$\mathrm{Zr}-\mathrm{OH} \quad$ Hidróxido de zircônio

$\mathrm{ZrSiO}_{4} \quad$ Zircão, Zirconita ou silicato de $\mathrm{Zr}$.

ZTA

Alumína tenacificada com zircônia (Zirconia toughened alumina)

$\mu \mathrm{g}$

Micrograma 



\section{SUMÁRIO}

1 INTRODUÇÂO E REVISÃO DE LITERATURA 15

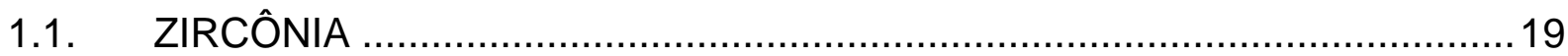

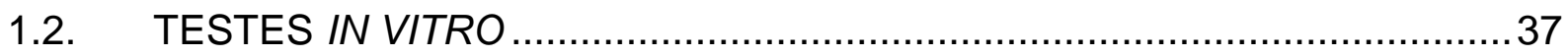

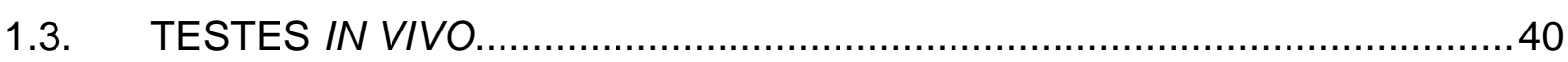

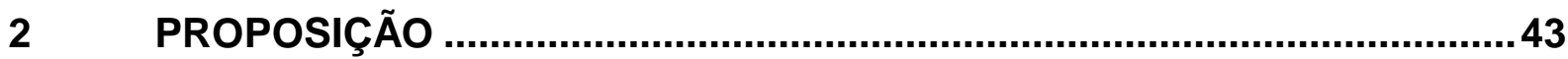

2.1. ESPECIFICAMENTE PRETENDEMOS ……...................................... 45

$3 \quad$ MATERIAIS E MÉTODOS

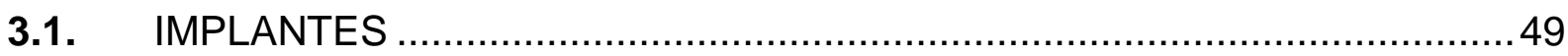

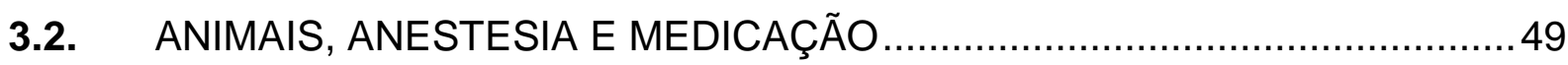

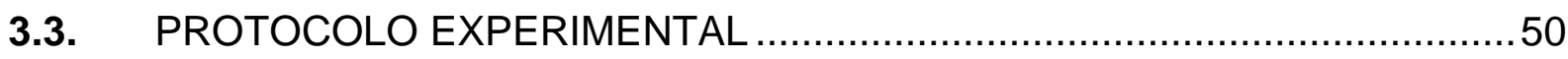

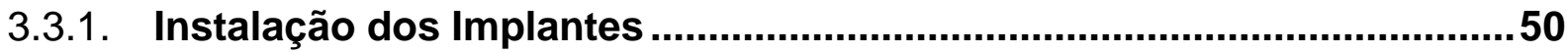

3.3.2. Procedimentos Cirúrgicos para Instalação dos Implantes.....................52

3.3.3. Administração pós-cirúrgica dos marcadores de neoformação óssea para análise ao Microscópio Confocal 55

3.3.4. Eutanásia dos animais, coleta e fixação das peças anatômicas. 55

3.3.5. Processamento das peças para inclusão em resina

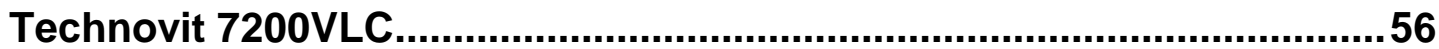

3.3.6. Análise histomorfométrica com o microscópio confocal .......................63

3.3.7. Cortes com $\mathbf{3 0}$ micrometros de espessura corados pelo Azul de toluidina para determinação do contato osso implante - BIC e áre a óssea - BA 68

3.4. ANÁLISE ESTATÍSTICA 68 



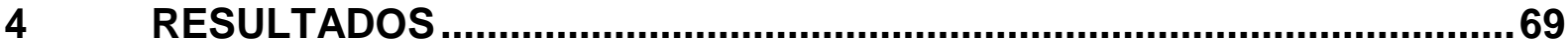

4.1. DADOS CLÍNICOS E PONDERAIS ......................................................

4.2. MARCADORES DE DEPOSIÇÃO ÓSSEA

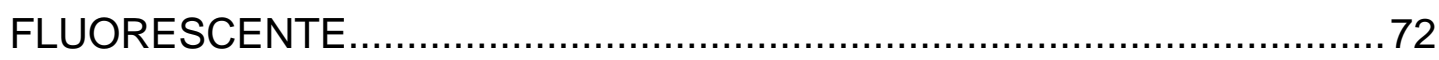

4.2.1. Descrição morfológica do padrão de marcação ao microscópio confocal

4.2.2. Quantificação do percentual de marcação - comparação entre os sexos. 89

4.2.3. Quantificação do percentual de marcação - comparação entre grupos. 92

4.3. FORMAÇÃO ÓSSEA NA SUPERFÍCIE DOS IMPLANTES AVALIADOS NOS CORTES DE TECIDO DURO CORADOS PELO AZUL DE TOLIDINA

4.3.1. Descrição morfológica dos cortes teciduais corados pelo Azul de Toluidina. 95

4.3.2. Percentual BIC e BA - comparação entre sexo 117

4.3.3. Percentual BIC e BA - comparação entre grupos 119

5 DISCUSSÃO 123

6 CONCLUSÃO 135

7 REFERÊNCIAS 139

ANEXOS 157 



\section{INTRODUÇÃO E REVISÃO DE LITERATURA}





\section{INTRODUÇÃO e REVISÃO DE LITERATURA}

Durante anos o homem vem tentando substituir os elementos dentários perdidos por dentes artificiais com o intuito de restabelecer a estética e a função mastigatória. Com o passar dos anos e com o avanço tecnológico os materiais sofreram um aprimoramento considerável e concomitantemente a exigência estética do paciente aumentou, tornando-se o restabelecimento do conforto e função prérequisitos básicos de todo tratamento (CAPELLOZA FILHO et al., 2001). Com esse intuito, cada vez mais novos materiais têm sido desenvolvidos para melhorar a durabilidade e aceitação estética (KELLY, 1997; ODÉN et al.,1998; KIM et al., 2007).

Implante dental é um material, metálico ou cerâmico (Figura 1), que é instalado com o objetivo de suporte para uma prótese unitária fixa, semi-fixa ou removível. O sucesso significativo de restaurações dentais, unitárias ou múltiplas suportadas por implantes, tornou as próteses tradicionais removíveis um tratamento com menor aceitação por parte dos pacientes (EMBACHER FILHO, 2003). O aumento da demanda desses pacientes por melhores resultados estéticos tem resultado em pesquisas para o desenvolvimento de novos componentes, materiais e conceitos de tratamento. Por muitas décadas o material mais utilizado na preparação de implantes tem sido o titânio. Uma conexão estrutural entre o osso vivo e a superfície do implante de titânio define o termo osseointegração. Os primeiros implantes na fase de osseointegração foram realizados na Suécia, onde a primeira preocupação foi com a reabilitação da função, depois com a higienização e por último com a estética (BRÅNEMARK et al., 1969). No Brasil, as primeiras impressões sobre os implantes osseointegrados não foram satisfatórias devido ao aparecimento do metal e da coloração escura resultante, retardando o processo de aceitação dos mesmos (SCHIROLI, 2004; TRIPODAKIS, 1995). O conjunto utilizado na substituição de dentes unitários por coroas implanto-suportadas consiste de um implante, que pode ser parafusado, geralmente de titânio ou de liga de titânio Ti-6Al$4 \mathrm{~V}$, de um pilar protético ("abutment") que até o início da década de 90 era confeccionado praticamente a base de metais, mas vem sendo substituído por materiais cerâmicos como alúmina e zircônia, e do material de cobertura estética, também de cerâmica (CARBONARI et al., 2010). Atualmente, a busca por estética 
imediata projeta o futuro do implantes para busca de novas tecnologias. Materiais cerâmicos a base de zircônia e zircônia-alúmina estão sendo estudados como substitutos dos materiais metálicos com o objetivo de mimetizar a natureza na coloração original dos dentes e suas implicações junto aos tecidos moles de revestimento. A utilização de materiais metálicos, semelhante ao que acontece nas coroas totais e próteses fixas com infraestrutura metálica, dependendo das características do tecido mole, resulta em um aspecto escurecido após a implantação da coroa, o que não acontece quando são utilizados os materiais cerâmicos (KOHAL et al., 2004; SENNERBY et al., 2005; QUAN et al., 2008). Os primeiros implantes de cerâmica foram introduzidos em 2005 para serem utilizados em reabilitações unitárias e representavam, na ocasião, um avanço considerável em relação à estética quando combinados com coroas confeccionadas em cerâmica, produzindo melhor translucidez e significativa harmonia na transição entre a restauração e os tecidos gengivais peri-implantares (HEYDECKE et al., 1999).

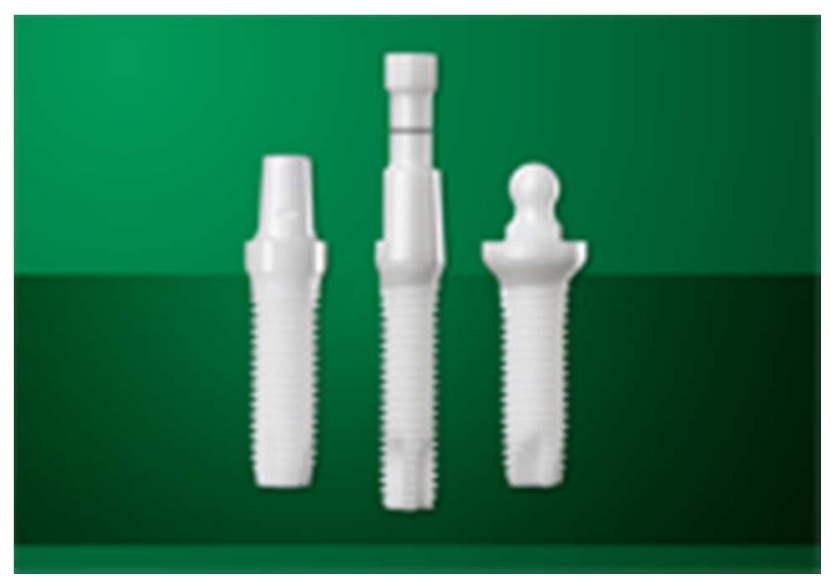

Figura 1. Exemplo de implante de corpo único produzido pela empresa Z-System.

Além da reabilitação estética, as cerâmicas apresentam vantagens incontestáveis principalmente quanto as suas características de durabilidade química, resistência ao desgaste, biocompatibilidade e propriedades ópticas (PASTOR, 2004). Os materiais cerâmicos também são excelentes para a confecção de pilares protéticos, uma vez que apresentam um potencial de colonização bacteriana muito baixo, devido ao polimento da cerâmica, o que representa um baixo grau de complicações inflamatórias em relação aos tecidos peri-implantares (RIMONDINI et al., 2002; SCARANO et al., 2004). 
A alúmina tem sido utilizada na odontologia para aumentar a resistência à flexão e a estética em próteses fixas desde 1965, e os primeiros pilares protéticos em alúmina foram introduzidos em 1993, mas têm sido substituídos por pilares de zircônia (Y-TZP), desde 1997, visto que esses apresentam superioridade mecânica sobre os outros tipos de cerâmicas odontológicas (AMARAL et al., 2004). Considerando-se a resistência à flexão e tenacidade à fratura, respectivamente, as porcelanas e vitro-cerâmicas (à base de leucita) apresentam valores em torno de $150 \mathrm{MPa}$ e 1,5 MPa.m ${ }^{0,5}$, as vitro-cerâmicas à base de dissilicato de lítio (Empress 2) apresentam valores ao redor de $300 \mathrm{MPa}$ e 3,0 MPa.m $\mathrm{m}^{0,5}$, a alúmina infiltrada por vidro (In-Ceram alúmina) apresenta valores ao redor de $450 \mathrm{MPa}$ e 4,0 MPa.m ${ }^{0,5}$, a alúmina infiltrada por vidro e modificada com 33\% de zircônia (In-Ceram Zircônia) apresenta valores ao redor de $600 \mathrm{MPa}$ e 5,0 MPa.m $\mathrm{m}^{0,5}$, e finalmente a Y-TZP apresenta valores ao redor $900 \mathrm{MPa}$ e 9,0 MPa.m ${ }^{0,5}$ (GUAZZATO et al., 2004; LAWN et al., 2001; LUTHY, 2005; RAIGRODSKI, 2004). Por causa desses altos valores, a Y-TZP é chamada de cerâmica odontológica "ultra-resistente" (KELLY et al., 1995), sendo a única indicada pelos fabricantes para a realização de próteses parciais fixas de quatro elementos na região posterior da arcada dental (LUTHY, 2005).

\subsection{ZIRCÔNIA}

A zircônia $\left(\mathrm{ZrO}_{2}\right)$ é uma cerâmica que vem se destacando não só na Engenharia como também na Medicina e na Odontologia, pela propriedades interessantes e peculiares que apresenta (PINHEIRO, 2008).

Este material é usado rotineiramente em Engenharia para a confecção de ferramentas de corte, refratários, abrasivos, opacificadores e outros materiais estruturais, sendo mais recentemente utilizado na confecção de sensores de oxigênio, células de combustão e recobrimentos térmicos. Enquanto na Medicina o seu emprego maior é na confecção de próteses ortopédicas (PINHEIRO, 2008). 
A zircônia ou óxido de zircônio $\left(\mathrm{ZrO}_{2}\right)$ foi descoberta em 1789 por Martin Heinrich Klaproth, que observou ser possível sua obtenção por meio de várias reações químicas a partir do zircão, procedente do Ceilão. $O$ tratamento químico realizado incluía uma fusão alcalina com hidróxido de sódio, seguida de uma extração com ácido clorídrico. A solução continha um elemento que apresentava um novo comportamento e quando tratado por uma base, originava um produto insolúvel que, após calcinação, dava origem a um novo óxido metálico (HAHN, 1961).

Esses óxidos são encontrados principalmente como minerais, na forma de zirquita e badeleita $\left(\mathrm{ZrO}_{2}\right)$ ou como zircão $\left(\mathrm{ZrSiO}_{4}\right)$. A maioria dos materiais contendo zircônia usados em cerâmica é extraído quimicamente do minério. Todas as zircônias comerciais costumam ter $2 \%$ de háfnio (STEVENS, 1986).

A partir desta descoberta seguiram-se alguns trabalhos sobre o óxido de zircônio ou zirconia, porém, devido à dificuldades experimentais, à presença de impurezas e ao desconhecimento de técnicas mais adequadas, somente após 35 anos, Berzelius obteve em 1824, a zircônia na forma metálica por redução do fluorzirconato de potássio com potássio metálico (FARNWORTH et al., 1984).

Em 1922, Hevest \& Coster descobriram que os compostos de zircônia sempre continham pequenas quantidades do elemento háfnio, de número atômico 72 . A existência deste elemento foi prevista por Mendellev em 1870 e suas propriedades mais importantes foram previstas por Bohr a partir da teoria do elétron (CLARK et al., 1973), e em 1925, Van der Arkel e De Boer obtiveram a zircônia compacta com alto grau de pureza pelo método da dissociação térmica do composto $Z r l_{4}$ (ELINSON \& PETROV, 1965).

Garvie \& Hannink (1975) relataram que as cerâmicas à base de zircônia poderiam apresentar resistência mecânica e tenacidade à fratura semelhante aos metais. Desde então, muitas pesquisas vêm sendo desenvolvidas visando a produção desse tipo de cerâmica, objetivando a obtenção de um material que apresente mecanismos que permitam um maior poder de absorção e dissipação da energia mecânica aplicada que resultará em uma maior resistência à fratura e à fadiga. 
Richerson (1992) relatou que a zircônia, além de ser bom isolante térmico e elétrico também apresenta outras características como: baixo coeficiente de dilatação térmica (alta estabilidade dimensional), alta resistência à abrasão e à oxidação, bem como elevada dureza.

$\mathrm{Na}$ Engenharia, a zircônia é um material selecionado tanto para estruturas, como para recobrimentos térmicos (SCARDI et al., 1997; SCHACHT et al., 1998; ANTOU et al., 2005; ROY et al., 2005) devido às seguintes características:

Alta estabilidade dimensional: Esta característica tem relação direta com sua dureza e pelas acomodações de sua microestrutura, que são estáveis devido à força de suas ligações. Sua dureza na escala Vickers está em torno de 1400.

Coeficiente de expansão térmica: Está relacionado à forma como os átomos estão organizados em sua estrutura cristalina e às forças de ligações interatômicas. Nos materiais cerâmicos como a zircônia, predominam as ligações iônicas (80\% em média), que são extremamente fortes, pois possuem uma distância interatômica onde as forças de atração entre os átomos são iguais às forças de repulsão, ou seja, estão em uma região onde há um gasto mínimo de energia. Sendo assim, é necessário fornecer uma grande quantidade de energia ao material, para que sua distância interatômica seja alterada e o material consequentemente deformado.

Alta resistência à abrasão: A energia necessária para se retirar um elétron de um material cerâmico precisa ser muito alta, ou seja, apenas fontes de energia de alta intensidade conseguem afetar sua estrutura. Deste modo, a resistência à abrasão de um material como a zircônia é muito alta. Em materiais que apresentam ligações metálicas, a energia necessária é muito menor.

Resistência à oxidação e dureza elevada: Estas duas características estão diretamente relacionadas às forças de ligações químicas presentes que, por serem primordialmente iônicas tornam o material "inerte" à mistura espontânea com outros materiais (resistência à oxidação) e impedem que os íons se separem facilmente, tornando o material mais resistente.

Segundo Lawson (1995), a degradação das propriedades mecânicas da cerâmica no organismo acontece quando os cristais tetragonais da superfície do 
material transformam-se em cristais monoclínicos na presença de água. Essa transformação é induzida pela reação das moléculas de água com o óxido de zircônio, originando hidróxidos na superfície da trinca.

Ruiz \& Readdey (1996) relataram que as propriedades mecânicas da zircônia dependem de fatores microestruturais da cerâmica e do tamanho do grão. Grãos maiores exibem transformações espontâneas da fase tetragonal para monoclínica, grãos menores reduzem a velocidade de transformação (aumentam a tenacidade) e os grãos abaixo de $0,2 \mu \mathrm{m}$ impedem a transformação de tetragonal para monoclínica (reduzem a tenacidade). Afirmaram ainda que o tamanho do grão também é influenciado pela porcentagem de ítria para a retenção da fase tetragonal e pela temperatura de sinterização, por isso a etapa de sinterização no processamento cerâmico tem influência fundamental na estabilidade e nas propriedades mecânicas, já que é ela que determina o tamanho do grão. A sinterização em temperaturas elevadas por períodos longos geram grãos maiores. A Y-TZP possui fases cúbicas em sua composição, o que funciona como obstáculo para a estabilização da zircônia pela ítria, pois os grãos cúbicos ficam ricos em ítria enquanto os tetragonais ficam pobres e com menor estabilidade. Estes autores pesquisaram também os efeitos do tratamento térmico no comportamento mecânico, tamanho do grão e fases presentes na zircônia estabilizada por ítria e verificaram a presença da fase tetragonal e cúbica na faixa de temperatura de sinterização.

Médevielle et al. (1997) relataram que a resistência ao desgaste por fricção da zircônia reforçada com ítria ou magnésia parece não apresentar diferenças entre si, contudo, a zircônia com ítria mostra maior resistência em relação ao desgaste por impacto. Porém apresenta como desvantagens seu elevado custo e sua baixa resistência ao choque térmico (WEI \& LIN, 1998).

A adição de óxidos de estabilização, como $\mathrm{CaO}, \mathrm{MgO}, \mathrm{CEO}_{2}, \mathrm{Y}_{2} \mathrm{O}_{3}$ à zircônia pura permite gerar materiais multi-fásicos conhecidos como zircônia parcialmente estabilizada (PSZ), cuja microestrutura à temperatura ambiente geralmente consiste de zircônia cúbica como a fase principal, com zircônia monoclínica e tetragonal precipitadas como fase secundária. Estes precipitados podem existir dentro de limites do grão ou dentro dos grãos cúbicos da matriz 
(SUBBARAO, 1981). Em 1972 Garvie e Nicholson mostraram que a resistência mecânica da PSZ foi melhorada por uma distribuição homogênea e fina da fase monoclínica dentro da matriz cúbica. O desenvolvimento da zircônia como um material de engenharia foi marcado por Garvie et al. (1972), que em seu artigo "Ceramic Steel?" mostrou como fazer a melhor transformação de fase T-M em PSZ melhorar a resistência mecânica e a tenacidade da cerâmica de zircônia. Eles observaram que precipitados tetragonal metastável finamente dispersos dentro da matriz cúbica foram capazes de ser transformados para a fase monoclínica, quando a força exercida sobre eles pela matriz foi aliviada, isto é, avançando por uma fenda no material. Nesse caso, o campo de tensão associado à expansão, devido a transformação atua em oposição de fase para o campo de tensões que promove a propagação da fissura. Uma melhoria na tenacidade é obtida, porque a energia associada com propagação da fenda é dissipada tanto na transformação T-M como na superação das tensões compressivas devidas a expansão do volume.

O desenvolvimento de tais precipitados tetragonais metastáveis podem ser obtidos por meio da adição de $8 \% \mathrm{em}$ mol de $\mathrm{MgO}$ à $\mathrm{ZrO}_{2}$. Isto permite a formação de uma microestrutura completamente cúbica a $1800^{\circ} \mathrm{C}$, e a nucleação no interior da matriz de uma fase tetragonal metastável, durante o resfriamento controlado e 0 envelhecimento.

PSZ também podem ser obtidas no sistema $\mathrm{ZrO}_{2}-\mathrm{Y}_{2} \mathrm{O}_{3}$. No entanto, nesse sistema é também possível obter cerâmicas formadas à temperatura ambiente com apenas a fase tetragonal, chamada de TZP (RIETH et al., 1976; GUPTA et al., 1978).

Materiais de TZP, contendo aproximadamente 2-3\% em mol de $\mathrm{Y}_{2} \mathrm{O}_{3}$, são completamente constituídas por grãos tetragonais com tamanhos da ordem de centenas de nanômetros. A fração da fase tetragonal que permanece à temperatura ambiente é dependente do tamanho dos grãos, do teor de ítria e do grau de força exercida sobre eles pela matriz. As propriedades mecânicas da cerâmica de TZP dependerá de cada um desses parâmetros (PICONI e MACCAURO, 1999).

Várias cerâmicas de PSZ foram testadas como biomateriais, especialmente a Mg-PSZ, o qual foi testada extensivamente com resultados favoráveis. Mas a 
pesquisa e desenvolvimento desse material para aplicações biomédicas foi interrompida no início de 1990. Várias razões podem explicar este fato: Mg-PSZ são caracterizadas por uma porosidade residual, como é normal em materiais com tamanhos de grãos na faixa de 30-40 $\mu \mathrm{m}$. Isso pode influenciar negativamente a taxa de desgaste do polietileno - UHMWPE da cavidade articular que estão juntas com zircônia na cabeça do fêmur. Também podem ter sido levados em conta os aspectos tecnológicos. A sinterização da Mg-PSZ a temperaturas mais elevadas do que TZP $\left(1800^{\circ} \mathrm{C}\right.$ contra $\left.1400^{\circ} \mathrm{C}\right)$, o que implica a necessidade de fornos especiais. A precipitação e o desenvolvimento de precipitados tetragonais metastáveis, que ocorre durante o resfriamento, exige um controle rigoroso do ciclo de refrigeração, em termos de temperatura e de tempo, especialmente em temperaturas ao redor de $1100^{\circ} \mathrm{C}$ onde $\mathrm{o}$ processo de envelhecimento tem lugar e durante o qual a precipitação de fases T ocorre.

As propriedades mecânicas da zircônia dizem respeito à sua granulação fina e microestrutura metaestável. A estabilidade desta estrutura durante a vida útil dos componentes TZP é o ponto chave para atingir os resultados e desempenhos esperados.

A degradação das propriedades mecânicas da zircônia, conhecida como "envelhecimento", se dá devido a uma progressiva e espontânea transformação da fase tetragonal metastável na fase monoclínica. Este comportamento é bem conhecido na faixa de temperaturas acima de $200^{\circ} \mathrm{C}$ na presença de vapor de água (SATO \& SHIMADA, 1985).

As principais etapas do envelhecimento das cerâmicas de TZP foram resumidos por Swab:

- A faixa mais crítica de variação de temperatura se dá entre os 200 e $300 \stackrel{\circ}{ } \mathrm{C}$;

- Os efeitos do envelhecimento são a redução da força, resistência e densidade e um aumento no conteúdo de fase monoclínica;

- A degradação das propriedades mecânicas se dá devido a transformação T$\mathrm{M}$, ocorrendo com as micro e macro trincas no material;

- A transformação T-M começa na superfície e progride em direção ao volume do material; 
- A redução no tamanho de grão e ou aumento na concentração de óxido estabilizador reduzem a taxa de transformação;

-A transformação T-M é aumentada na presença de água ou vapor;

Os modelos propostos para explicar a transformação T-M espontânea nas cerâmicas de TZP baseiam-se na formação de hidróxidos de zircônio ou hidróxidos de ítrio, promovendo a transformação de fase em locais de concentração de stress ou de variação da proporção Zn-Y (SATO \& SHIMADA, 1985; YOSHIMURA et al., 1987).

A variação no comportamento durante o envelhecimento é atribuída a diferenças nos parâmetros microestruturais, como a concentração e distribuição da ítria, o tamanho do grão e falhas na distribuição das amostras testadas.

A variação da resistência à flexão das amostras TZP implantadas na cavidade medular e nos músculos paravertebrais de coelhos NZW ou mantidas em solução salina fisiológica a $37{ }^{\circ} \mathrm{C}$ durante 12 meses, foi investigado por Kumar et al. em 1989. Um aumento da resistência à flexão foi observada depois de seis meses, associados com $2 \%$ de formação de fase $\mathrm{M}$ nas superfícies das amostras. Os dados experimentais relatados por Schwartz em 1990 e por Christel em 1989 estão de acordo com aqueles de Kumar. Christel et al., em 1989, mostraram que a esterilização por raios gama ou o envelhecimento em solução de Ringer por 100 dias não induziu variações significativas na resistência das amostras de TZP. Além disso, Ichikawa et al. (1992) não observou variação na resistência à flexão das amostras de TZP após 12 meses de envelhecimento em ar, solução salina, ou em tecido subcutâneo de ratos Wistar. Shimizu et al. (1993) testaram amostras de TZP (tamanho de grão de 0,25 $\mu \mathrm{m}$, densidade de $6 \mathrm{~g} \mathrm{~cm}^{-3}$ ), in vitro e in vivo. Os testes in vitro foram realizados em solução salina a $37,50,95^{\circ} \mathrm{C}$ durante 36 meses e em autoclave a $121{ }^{\circ} \mathrm{C}$ durante $960 \mathrm{~h}$. As amostras foram testadas quanto in vivo em tíbia de coelhos durante 30 meses. Ensaios de flexão de três pontos foram realizados em amostras medindo $8 \mathrm{~mm}$. A alúmina foi utilizada como controle. As amostras testadas a $37^{\circ} \mathrm{C}$ in vitro e in vivo não mostraram diferenças significativas. O desenvolvimento da fase monoclínica sobre a superfície das amostras foi observada apenas 90 dias após o início do teste, atingindo cerca de 2 e 5\% molar ao 
fim de 12 e 30 meses, respectivamente. Em correspondência com a transformação da superfície T-M, foi observado um aumento na resistência à flexão das amostras, mas o valor inicial foi recuperado após 30 meses. Nas amostras examinadas, a 50 ${ }^{\circ} \mathrm{C}, 16 \%$ em mol da superfície foram submetidos a uma transição de T-M após 3 anos. O aumento correspondente na resistência a flexão foi de cerca de $10 \%$. A fase monoclínica foi de $69 \%$ em mol, em amostras envelhecidas a $95^{\circ} \mathrm{C}$, após 27 meses, ao passo que nas amostras envelhecidas em auto-clave a $121^{\circ} \mathrm{C}$, a fase monoclínica, foi cerca de $50 \%$ em mol, após 500 h, só sendo de $80 \%$ em mol após $1000 \mathrm{~h}$.

União de $\mathrm{Zr}-\mathrm{OH}$ foram identificados por FTIR (Fourier transform infrared spectroscopy) em amostras envelhecidas por $960 \mathrm{~h}$ em água a $121^{\circ} \mathrm{C}$. Isto sugere que a fase de transição do material testado depende de mecanismos semelhantes aos propostos por Sato e Shimada (1985) ou por Yoshimura et al. (1987), a formação de uniões $\mathrm{Zr}-\mathrm{OH}$ como sendo o iniciador da transição. No entanto, nenhuma microfissura foi observada por MEV em amostras de material idêntico, com idades compreendidas entre $1920 \mathrm{~h}$ em solução salina a $121^{\circ} \mathrm{C}$. A energia de ativação do processo de transição do material testado, foi calculada como sendo de cerca de $21,5 \mathrm{kcal}$ mol-1. Este resultado permitiu aos autores predizerem que a resistência à flexão do material poderia se manter por 80 anos em valores superiores a $800 \mathrm{MPa}$.

Chevalier et al. em 1977 apresentaram os resultados de um estudo sobre a cinética da transformação T-M da TZP obtida a partir de pós co-precipitados. Estes resultados permitiram prever um período de envelhecimento de 25 anos a $37^{\circ} \mathrm{C}$ para atingir $20 \%$ de conteúdo monoclínico nas suas amostras. A energia de activação medidos (log kJ mol-1) é da mesma ordem da medida por Shimizu et al. (1993).

Os testes da zircônia como biomaterial tiveram inicio no final dos anos sessenta. O primeiro artigo relativo à aplicação biomédica de zircônia foi publicado em 1969 por Helmer e Driskell, enquanto que o primeiro artigo sobre a utilização de zircônia para a fabricação de próteses de cabeça de fêmur para artroplastias totais do quadril (THR), que é a atual principal aplicação deste biomaterial cerâmico, foi introduzido por Christel et al. em 1988. 
Nos estágios iniciais do desenvolvimento, várias soluções sólidas $\left(\mathrm{ZrO}_{2}-\mathrm{MgO}\right.$, $\mathrm{ZrO}_{2}-\mathrm{CaO}, \mathrm{ZrO}_{2}-\mathrm{Y}_{2} \mathrm{O}_{3}$ ) foram testados para aplicações biomédicas, mas, nos anos seguintes, os esforços em pesquisa foram mais focados em cerâmica de zircôniaítria, caracterizada por microestruturas de granulação fina, conhecidos como policristais de zircônia Tetragonal (TZP).

Hoje em dia a cerâmica de TZP, cujos requisitos mínimos como implantes para cirurgia estão descritos na norma ISO 13356, são os materiais de escolha por quase todos os fabricantes que estão produzindo próteses de cabeça de fêmur. Mais de 300.000 próteses de quadril - TZP foram implantadas (CHEVALIER et al., 1977), e existem algumas falhas relatadas até agora.

Bottino em 2000 afirmou que a alta resistência flexural e a tenacidade do sistema ICZ (alumina infiltrada por vidro reforçada por zirconia) são explicadas devido à presença de $33 \%$ de óxido de zircônio, além de óxido de alumina.

Hannink et al. em 2000 afirmaram que a principal limitação das cerâmicas está na baixa reprodutibilidade de seus valores de resistência mecânica, proveniente da relação direta com quantidade e distribuição de defeitos intrínsecos e extrínsecos presentes em sua estrutura e também com as características inerentes de um material frágil. Nesses materiais, as trincas se iniciam em defeitos que são introduzidos durante o processo de fabricação (poros, inclusões ou agregados), acabamento superficial (polimentos) ou durante a sua exposição à ambientes quimicamente agressivos. Porém, as trincas podem ser interrompidas ou ter sua velocidade de propagação reduzida se sua energia puder ser absorvida por eventos como o encontro com inclusões, contornos de grão, ou ainda, em uma transformação de fase cristalina na região da ponta da trinca que possa alterar o campo de tensões, sendo este fenômeno que ocorre nas cerâmicas de zircônia parcial ou totalmente composta pela fase tetragonal.

De Aza et al. em 2002 afirmaram que as cerâmicas Y-TZP de alta densidade relativa vem sendo utilizadas devido à sua excelente biocompatibilidade, alta dureza, resistência à flexão e ao desgaste, bem como alta tenacidade à fratura.

O notável comportamento mecânico da zircônia deve-se principalmente ao mecanismo de tenacificação presente nesses materiais que é chamado de 
transformação martensítica. A zircônia é uma cerâmica polimórfica que apresenta três formas alotrópicas cristalinas bem definidas: monoclínica, tetragonal e cúbica que são estáveis em diferentes temperaturas. Em seu estado natural e a temperatura ambiente a zircônia exibe simetria monoclínica sendo estável em temperaturas de até aproximadamente $1170^{\circ} \mathrm{C}$. Entre $1170^{\circ} \mathrm{C}$ e $2370^{\circ} \mathrm{C}$ a zircônia se modifica para a fase tetragonal, que possui um volume reduzido quando comparada à monoclínica. Esta fase pode ser estabilizada na temperatura ambiente dependendo do tamanho da partícula de zircônia e da concentração de óxidos estabilizadores adicionados à sua estrutura. Acima de $2370^{\circ} \mathrm{C}$ até a fusão $(2680 \pm$ $15^{\circ} \mathrm{C}$ ) a zircônia se encontra na fase cúbica (VENA et al., 2006), conforme mostra a figura 2. Em altas temperaturas ou após resfriamento rápido até temperaturas próximas ou inferiores à do nitrogênio líquido, observa-se uma estrutura com simetria ortorrômbica.

A propriedade da zircônia parcialmente estabilizada de sofrer transformação martensítica após a aplicação de uma tensão, gerando assim um material com maior tenacidade, é de suma importância para a sua seleção (KELLY \& DENRY, 2007, MANICONE et al., 2007).

Todavia, o uso da zircônia parcialmente estabilizada em temperatura ambiente somente é possível por meio da adição de óxidos metálicos como a ítria $\left(\mathrm{Y}_{2} \mathrm{O}_{3}\right.$ ), magnésia ( $\mathrm{MgO}$ ) e a céria (CeO) (KELLY \& DENRY, 2007; MANICONE et al., 2007), uma vez que a transformação de fase de tetragonal para monoclínica causa expansão volumétrica de 3 a $5 \%$ e, por isso, trincas inviabilizariam o uso do material.

Ortorrômbica $\leftrightarrow$ monoclinica $1170^{\circ} \mathrm{C} \leftrightarrow$ tetragonal $\left.\right|^{2370^{\circ} \mathrm{C}} \leftrightarrow$ cúbica $^{2680^{\circ} \mathrm{C}} \leftrightarrow$ liquida

Figura 2. - Formas alotrópicas da zircônia 
As estruturas cristalográficas da zircônia estão exemplificadas na figura abaixo:

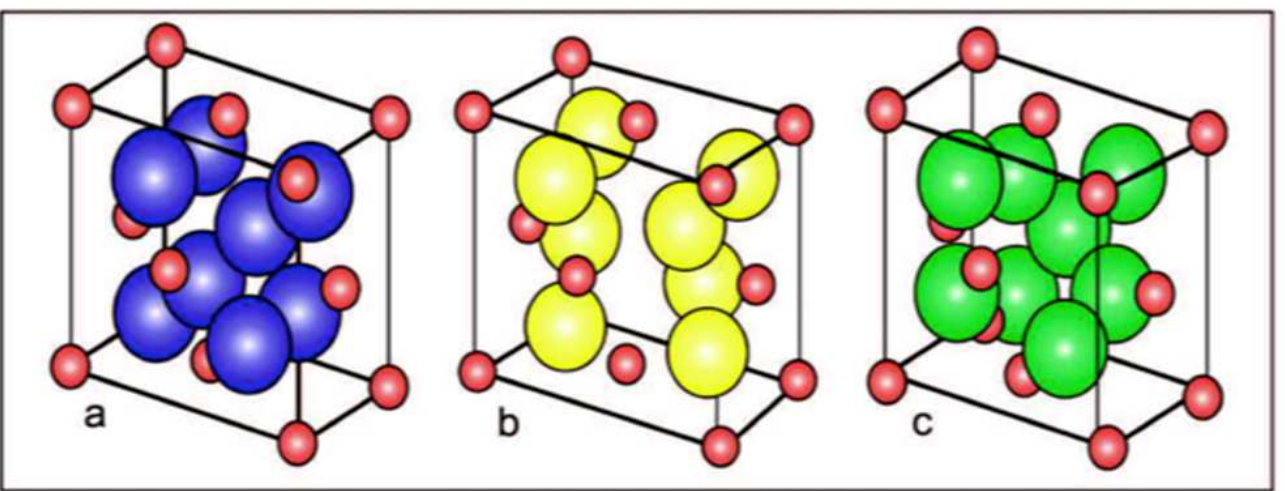

Figura 3. - Estruturas cristalográficas da zircônia. Monoclínica (a), Tetragonal (b) e Cúbica (c). (HANNINK et al., 2000).

Essa transformação se dá por meio de um processo de cisalhamento não difusional em velocidades próximas à do som. Além disso, durante o processo ocorre uma expansão volumétrica que pode variar de 3 a 5\%. Quando um aditivo como a ítria é adicionado em uma proporção de $3 \%$ à zircônia, ocorre uma estabilização da fase tetragonal à temperatura ambiente. A cerâmica de zircônia com 2 e $3 \%$ em mol de $\mathrm{Y}_{2} \mathrm{O}_{3}$ é sinterizada ao redor de $1500^{\circ} \mathrm{C}$, apresenta tamanho de grão fino ( $1 \mu \mathrm{m}$ ou menos) e baixíssima porosidade, o que resulta em elevada resistência à flexão (até $\sim 1 \mathrm{GPa})$, tenacidade à fratura ( 10 $\left.\mathrm{MPa} \cdot \mathrm{m}^{0.5}\right)$, dureza $(\sim 1,4$ GPa) e resistência ao desgaste erosivo (BIRKBY et al., 1996). As cerâmicas Y-TZP, entretanto, podem apresentar degradação catastrófica em atmosferas secas e úmidas na faixa de temperatura entre 65 e $500^{\circ} \mathrm{C}$ devido à desestabilização da fase tetragonal para monoclínica (LAWSON, 1995). O controle microestrutural das cerâmicas Y-TZP é fundamental para produção de próteses com elevada confiabilidade. 
Inicio do trincamento

Estágio inicial de propagaçăa da trinca

Estágio final de

propagaçăo da trinca

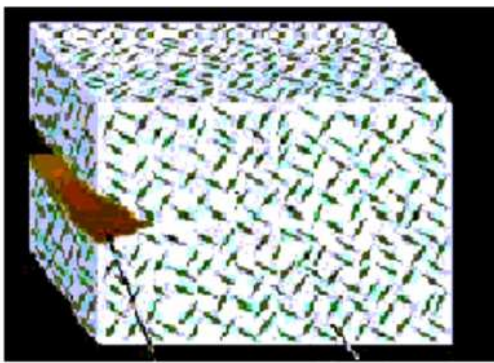

Trinca
Matriz

2. Partículas de Zircónia na fase tetragonal na matriz de Alumina

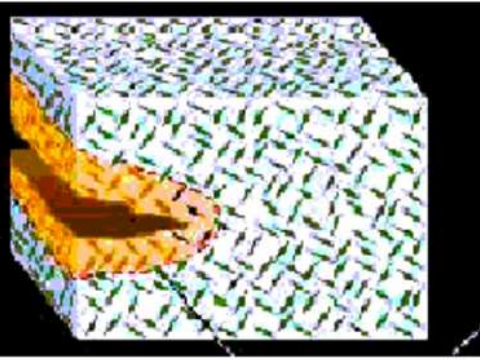

Campo de tens 50 inibindo a propagaçåa da trinca

5. Particulas de Zircónia na fase tetragonal se transformando Dara a fase monocliinica

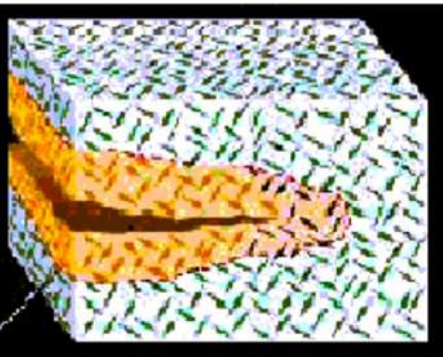

Y. Particulas de Zircónia na fase monoclinica

Figura 4 - Mecanismo de aumento de tenacidade por transformação de fase. SÁ \& MORAES, 2004

A estabilização parcial da zircônia por meio de óxidos permite mantê-la na fase tetragonal metaestável em condições ambiente e o campo de tensões frente a uma trinca que se propaga faz com que essas partículas tetragonais mantidas metaestavelmente sofram transformação para a fase monoclínica estável. Acompanhando esta transformação, há um ligeiro aumento de volume e o resultado é que são estabelecidas tensões compressivas sobre as superfícies da trinca nas regiões próximas à sua extremidade, que tendem a fechar a trinca, obstruindo o seu crescimento (CALLISTER JUNIOR, 2002).
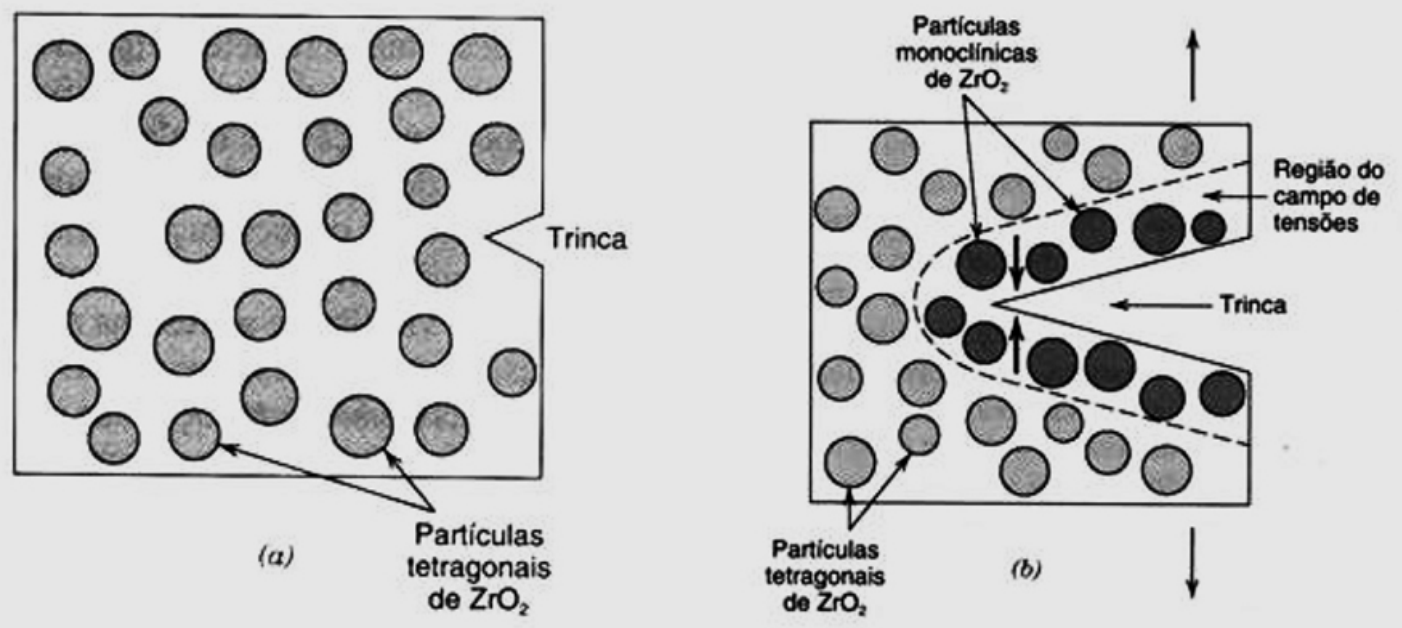

Figura 5 - Esquema do mecanismo de tenacificaçāo da zircônia por transformação de fase. Modificada da fonte; CALLISTER JUNIOR, 2002. 
Uma revisão publicada em 2006, atentou para o fato de que em 2001, aproximadamente 400 próteses de cabeça de fêmur de Y-TZP, da marca Prozyr (Saint Gobain), fraturaram em um curto período de tempo, o que colocou a comunidade médica diante de um dilema e levou a uma queda de mais de $90 \%$ nas vendas dessas próteses entre 2001 e 2002, destruindo essa marca. O problema aparentemente ocorreu com a mudança de processo de forno de batelada para forno contínuo, onde uma pequena alteração no ciclo de sinterização causou a produção de lotes com variação na microestrutura (CHEVALIER, 2006). A degradação das propriedades mecânicas da Y-TZP no organismo ("aging") ocorre quando, na presença de água, os cristais tetragonais da superfície do material transformam-se em monoclínicos (DEVILLE et al., 2005). Essa transformação é induzida pela reação das moléculas de água com o óxido de zircônio, formando hidróxidos na superfície da trinca (DE AZA et al., 2002). A transformação T-M de um grão leva a um aumento de seu volume, gerando tensões ao seu redor e resultando no surgimento de microtrincas. Essas trincas funcionam como uma passagem, permitindo que mais água penetre na estrutura, levando mais grãos a se transformarem e conseqüentemente gerando mais trincas e aumentando a rugosidade da superfície (CHEVALIER, 2006). Análises de difração de raios $X$ têm sido utilizadas para acompanhamento quantitativo dessas transformações. Chevalier em 2006 relatou que, como cerâmicas obtidas de pós de zircônia de diferentes procedências, ou mesmo de diferentes processos de fabricação, podem apresentar microestruturas diferenciadas, há uma necessidade de analisar a sensibilidade de degradação de cada uma delas. Essa análise pode ser realizada por meio de testes acelerados "in vitro". Chevalier et al., nesse mesmo ano (2006), chegaram à conclusão que cerâmicas de Y-TZP submetidas a $134^{\circ} \mathrm{C}$ por $1 \mathrm{~h}$, em autoclave, têm teoricamente o mesmo efeito que 3 a 4 anos in vivo. Esses autores ainda recomendam que cerâmicas a base de zircônia de Y-TZP, para aplicação médica ou odontológica, devem apresentar tamanho de grão inferior a $0,4 \mu \mathrm{m}$, que a quantidade de fase monoclínica não deve ser superior a $20 \%$ e que o teste de degradação é fundamental para assegurar a qualidade desses materiais. Inclusive sugere que o teste de degradação seja incluído na norma ISO 13556, que regulamenta os requisitos mínimos de implantes siderúrgicos. 
As falhas ocorridas nas próteses Prozyr, em 2001, estão levando a comunidade científica e clínica a estudar profundamente o comportamento da zircônia, especialmente com relação à degradação in vitro e in vivo. Esses estudos são fundamentais para a comunidade médica readquirir confiança nos implantes cerâmicos (CHEVALIER et al., 2007). O uso de zircônia para implantes dentários é relativamente novo e a comunidade odontológica parece não estar suficientemente preocupada com o problema da degradação da Y-TZP no organismo, já que o mercado de vendas desse material tem crescido mais de $12 \%$ por ano (CHEVALIER, 2006).

Chevalier em 2007 relatou que, pelo menos a curto e médio prazo, a solução é o desenvolvimento de compósitos alumina-zircônia. Nos compósitos de alumina tenacificada com zircônia (ZTA), a zircônia tem sido adicionada para aumentar as propriedades mecânicas da alumina, mas no caso de compósitos de alumina tenacificada com mais de $16 \%$ em volume de zircônia (3Y-TZP), a degradação pode ser significativa. De Aza et al., em 2002, estudaram algumas propriedades de compósitos alumina-zircônia obtidas por duas rotas: uma com adição de $10 \%$ em volume de $\mathrm{ZrO}_{2}$, obtidas a partir da mistura de óxidos e moagem para obtenção de granulometria fina e de outra de coprecipitação de $\mathrm{ZrO}_{2}$, em uma suspensão de alumina. Os autores chegaram a conclusão que o método de copreciptação resulta na formação de partículas nanométricas de zircônia dispersas homogeneamente na matriz de alumina, evitando aglomerados, e minimizando falhas microestruturais. Devido ao pequeno tamanho dos grãos e da distribuição uniforme dos mesmos é possível reter uma grande quantidade de grãos de zircônia tetragonal contribuindo para o mecanismo de tenacificação e de resistência à degradação. Os resultados acima mostram a importância de se controlar o processo de sinterização da cerâmica Y-TZP para manter o grão fino.

Ainda em 2006 Curtis et al. realizaram um estudo objetivando investigar a influência da simulação de forças mastigatórias, que ocorrem no meio bucal durante a vida útil de uma reconstrução com cerâmica Y-TZP. Foram avaliadas a resistência a flexão, módulo de Weibull e dureza de superfície de corpos de prova em forma de discos (13 mm de diâmetro x $1.54 \mathrm{~mm}$ de altura) obtidos a partir de um bloco cerâmico com 5-mol\% de Y-TZP (LAVA-3M ESPE). As amostras foram divididas em 
10 grupos com 30 espécimes cada. $O$ grupo $A$ e $E$ foram mantidos nas condições "recebidas" como grupo controle; o grupo B e D foram submetidos a 2000 ciclos contínuos a $500 \mathrm{~N}(383$ - $420 \mathrm{MPa}), 700 \mathrm{~N}(536$ - $588 \mathrm{MPa})$ e $800 \mathrm{~N}(613-672$ $\mathrm{MPa}$ ). O grupo $\mathrm{F} \mathrm{e} \mathrm{H}$ também foi submetido a ciclos contínuos de carga e imersos em água a $37^{\circ} \mathrm{C}$ por 2000 ciclos a $500 \mathrm{~N} ; 700 \mathrm{~N}$ e $800 \mathrm{~N}$. O grupo I e J foi mantido seco e submetido a um máximo de $80 \mathrm{~N}(61-67 \mathrm{MPa})$ por $10^{4}$ e $10^{5}$ ciclos para simular o nível de força mastigatória que as coroas e PPF de cerâmica pura receberão ao longo de sua vida útil na cavidade oral. Em seguida os espécimes foram submetidos ao ensaio de Flexão e dureza Vickers. Os resultados foram submetidos a avaliação estatística e não mostraram diferença significante na resistência à flexão entre todos os grupos. Já o aumento do módulo de Weibull foi significante para os espécimes imersos em água comparados com o grupo controle, o grupo submetido a extenso ciclo de $10^{5}$ resultou numa significante redução do módulo de Weibull comparado com o grupo controle. Foram detectadas áreas com aumento da dureza de superfície diretamente abaixo da esfera do edentador. Os autores concluíram que o aparecimento de áreas com maior dureza de superfície pode ser resultado de um mecanismo de transformação da resistência ou aumento da densidade do material por esmagamento. A redução da confiabilidade dos espécimes submetidos a $80 \mathrm{~N}$ por $10^{5}$ ciclos foi associada ao acúmulo de dano crítico, como resultado das extensas forças mastigatórias.

Denry \& Kelly em 2008 afirmaram que a Y-TZP tornou-se uma alternativa como cerâmica estrutural, pois apresenta maior resistência à flexão, maior tenacidade à fratura e menor módulo de elasticidade que a alúmina e que a zircônia pura. Afirmou ainda que possui boa adesão com cerâmicas de recobrimento, excelente translucidez, boa estética quando polida e recoberta por material cerâmico. E que a transformação de fase da zircônia $(T \rightarrow M)$ frente a uma carga (estresse) é uma qualidade especial e desejável uma vez que a expansão em volume da partícula de zircônia dificulta a propagação da fratura, aumentando significativamente a resistência deste material, que por esta característica é conhecida como cerâmica inteligente. Isto acontece devido à incorporação de óxidos metálicos que controlam a transformação da zircônia $T \rightarrow M$, criando empecilho para a propagação de fraturas. Neste caso, essa transformação ocorre em uma área específica da cerâmica (região de estresse) ou ao longo do caminho da fratura, e 
não em toda a sua estrutura, como no caso da degradação por ação de baixas temperaturas $\left(120-400{ }^{\circ} \mathrm{C}\right)$, causando macro e micro trincas em toda superfície da cerâmica que se propagam para o seu interior, diminuindo a resistência mecânica da cerâmica.

Carbonari et al. em 2010 avaliaram as propriedades mecânicas de pilares cerâmicos estéticos a base de compósitos alumina-zircônia $\left(\mathrm{Al}_{2} \mathrm{O}_{3}-\mathrm{ZrO}_{2}\right)$ e zircônia estabilizada $\left(\mathrm{ZrO}_{2} \mathrm{Y}-\mathrm{TZP}\right)$, por meio de ensaios mecânicos, a fim de verificar sua viabilidade de produção e comercialização para utilização em procedimentos odontológicos. Os autores obtiveram pilares cerâmicos a base de compósitos de $\mathrm{ZrO}_{2}$ e $\mathrm{Al}_{2} \mathrm{O}_{3}-\mathrm{ZrO}_{2}$, que foram submetidos a ensaios mecânicos de fadiga cíclica úmida e carregamento por compressão tangencial. Os resultados foram avaliados por meio de avaliações macroscópicas dos corpos de prova, sobrevida de ciclos e valores de resistência à fratura, onde observou-se a possibilidade de se obter pilares de $\mathrm{ZrO}_{2}$ e $\mathrm{Al}_{2} \mathrm{O}_{3}-\mathrm{ZrO}_{2}$ usinados industrialmente, com elevada resistência mecânica e durabilidade clínica quando corretamente instalados e obedecendo um minucioso planejamento.

Gahlert et al. em 2010 comparando implantes, ambos com tratamento de superfície, de zircônia (ataque ácido) e titânio (SLA), concluíram não haver diferença estatística no processo de osseointegração entre os mesmos.

Lughi \& Sergo em 2010 realizaram um estudo de todos os dados experimentais sobre a degradação em baixa temperatura da zircônia (envelhecimento) decorrente da transformação de fase $(T \rightarrow M)$, que foram coletados nas temperaturas de interesse para aplicação dental (da temperatura ambiente até cerca de $100^{\circ} \mathrm{C}$ ). Foi demonstrado que os principais fatores que afetam o fenômeno de envelhecimento são o tipo e conteúdo de estabilizador, a tensão residual e o tamanho do grão. Os autores demonstraram também que a extrapolação da taxa de degradação em baixa temperatura a partir de ensaios de envelhecimento acelerado pode levar a conclusões inaceitáveis sobre a vida útil de componentes à base de zircônia.

Kohorst et al. em 2012 avaliaram a influência do envelhecimento simulado na transformação de fase $(T \rightarrow M)$ e sobre a resistência à flexão de uma cerâmica $Y$ - 
TZP em comparação à zircônia associada à alumina e zircônia estabilizada com céria. A hipótese a ser testada era que uma alta proporção de alúmina como também o uso de céria como um óxido estabilizador reduzem a susceptibilidade das cerâmicas de zircônia à fadiga hidrotérmica e, portanto, podem ter um efeito positivo no comportamento mecânico de pilares de implante e de restaurações dentais. Com base nos resultados, os autores concluíram que a zircônia associada com alumina parece ser o material mais favorável para a fabricação de restaurações dentais aplicadas no ambiente hidrotérmico da cavidade oral.

Testes in vitro tem mostrado que a zircônia tem menor toxicidade que o titânio e similar à alúmina. Citotoxocidade, carcinogenêse, mutagênicidade ou alterações cromossômicas em fibroblastos ou células sanguíneas não têm sido observados (VAGKOPOULOU et al., 2009).

Crescimento da zona transformada levando a extensive formação de microtrincas e rugosidade superficial. Os grãos transformados aparecem em cinza. As vias em vermelho representam a penetração da água devido a formação das microtrincas ao redor dos grãos transformados (CHEVALIER, 2006).

Classificação da Zircônia:

1 - Zircônia totalmente estabilizada:

Uma zircônia totalmente estabilizada na forma cúbica é obtida por meio da adição de quantidades suficientes de óxidos estabilizadores, tais como magnésia $(\mathrm{MgO})$, ítria $\left(\mathrm{Y}_{2} \mathrm{O}_{3}\right)$, céria $\left(\mathrm{CeO}_{2}\right)$, calcio $(\mathrm{CaO})$ e outros (RICHERSON, 2006).

No caso da ítria, uma concentração superior a $6 \% \mathrm{~mol}$, gera uma zircônia totalmente estabilizada (ESQUIVAS et al., 1996)

2 - Zircônia parcialmente estabilizada - PSZ:

A adição de óxidos estabilizadores em quantidade inferior à necessária para a estabilização completa da fase cúbica produz uma zircônia parcialmente estabilizada, havendo portanto, pequenas partículas de zircônia tetragonal metaestáveis dispersas em uma matriz de zircônia cúbica (RICHERSON, 2006, CUMBRERA et al., 1998). Uma concentração variando entre 3 à $6 \%$ mol de ítria é 
necessária para a obtenção de uma zircônia parcialmente estabilizada (ESQUIVAS et al., 1996).

\section{3 - Zircônia Tetragonal Policristalina - TZP:}

Uma zircônia tetragonal policristalina é constituída essencialmente pela fase tetragonal com uma concentração baixa de aditivos estabilizadores na faixa de menos que $3 \%$ mol para ítria, por exemplo (ESQUIVAS et al., 1996). Este material possui uma microestrutura homogênea com pequenos grãos $(0,1-1 \mu \mathrm{m})$ (RICHERSON, 2006). A temperatura de sinterização exerce uma grande influência no tamanho de grãos formados neste tipo de material, sendo assim, quando sinterizados em temperaturas mais baixas, grãos menores poderão ser obtidos (DENRY \& KELLY, 2008). Este material é, na verdade, uma zircônia parcialmente estabilizada (KOSMAC et al., 2000), devido a sua baixa concentração de aditivos estabilizadores, porém com características especiais em relação à microestrutura e tamanho dos grãos.

4 - Zircônia dispersa na matriz cerâmica:

A matriz mais utilizada com precipitados de zircônia é a de alúmina. Chevalier em 2006 incentivou o uso da zircônia em matriz de alúmina como sendo uma melhor alternativa em relação à zircônia com aditivos.

Um aspecto relevante para a estabilidade do material em ambiente biológico é a presença de fases vítreas formadas pelos $\mathrm{SiO} 2, \mathrm{Al} 2 \mathrm{O} 3 \mathrm{TiO} 2$ e impurezas de $\mathrm{CaO}$ em torno dos grãos. Estas impurezas podem ser provenientes de precursores químicos, a partir dos corpos de moagem utilizados no processamento dos pós, ou pode ser adicionado aos pós como auxiliares de sinterização. A sua presença conduz a uma perda de estabilidade da fase tetragonal, uma vez que foi demonstrado que fases vítreas de alumino-silicato em torno dos grãos são capazes de sequestrar íons de ítria a partir de grãos de TZP (LIN et al., 1990). Também acúmulos de mulita (3Al2O3.2SiO2) detectados em auxiliares de sinterização vitrificados estão levando à perda de estabilidade da zircônia em ambiente úmido.

Aceita-se agora que a tensão microscópica dispara o gatilho da transformação T-M dos grãos (SCHUBERT \& FREY, 2005). Tensões de tração 
macroscópicas podem desempenhar o mesmo papel (LI, ZHENG \& HASHIDA, 2001; DEVILLE, CHEVALIER \& GREMILLARD, 2006). Assim, o processo de fabricação tem de ser cuidadosamente controlado. Polimento grosseiro induz tensões de compressão que retardam o envelhecimento, mas o estado da superfície não é adequado para aplicações na área médica; polimento fino conduz a uma rugosidade aceitável, mas elimina a tensões de compressão e permite tensões de tração que aparecem ao longo dos riscos residuais. Assim, é necessário um polimento fino, sem arranhões.

Para resumir, o envelhecimento (LTD ou "AGING") é acelerado por grãos grosseiros, baixa densidade e proporção entre as fases C-T. Condições de sinterização têm de ser adaptadas para evitar essas características. Isto pode implicar a utilização de processos tais como HIP ou sinterização (também chamado faísca sinterização no plasma). O processo de fabricação tem de ser cuidadosamente controlado de modo a limitar a aparição de tensões residuais de tração sobre as superfícies expostas ao envelhecimento. No entanto, LTD pode ser abrandado, mas nunca completamente suprimido, 3Y-TZP. Outros materiais à base de zircônia ou contendo zircônia podem oferecer maior resistência ao envelhecimento.

$\mathrm{O}$ aumento do teor de $\mathrm{Y}_{2} \mathrm{O}_{3}$ melhora a resistência ao LTD (SATO \& SHIMADA, 1985). No entanto, aumentar o teor de estabilizante inibe a transformação de t-m e, assim, diminui as propriedades mecânicas do material (GREEN et al., 1989). Além disso, a proporção da fase C aumenta com o aumento do teor de $\mathrm{Y}_{2} \mathrm{O}_{3}$. Isso resulta, de novo, em uma perda de propriedades mecânicas e também numa difusão do $\mathrm{Y}_{2} \mathrm{O}_{3}$ para fora dos grãos tetragonais vizinhos da fase $\mathrm{C}, \mathrm{o}$ que pode provocar uma transformação t-m preferencial em torno dos grãos cúbicos (CHEVALIER et al., 2004).

\subsection{TESTES In Vitro}

Cerâmicas ou pós de zircônia foram testadas em diferentes linhagens celulares: alguns autores observaram que a zircônia não tem efeitos citotóxicos 
quando fibroblastos foram cultivados com eles ou com extratos utilizando diferentes métodos (viabilidade celular e ensaio de MTT) (DION et al., 1994; LI et al., 1993). Estudos de microscopia eletrónica de varredura (MEV) também relataram a adesão e o espalhamento dos fibroblastos 3T3 (BUKAT et al., 1990). Por outro lado foi observado maior inibição do crescimento celular utilizando zircônia e pó de TCP em comparação com a alúmina ou hidroxiapatita no ensaio de contato direto e de viabilidade celular MTT (LI et al., 1993). Em particular, a citotoxicidade da zircônia em pó (precursores cerâmicos) foi maior do que a citotoxicidade dos pós obtidos por esmagamento e moagem de cerâmica de zircônia sinterizada: este efeito estava relacionado com diferentes superfícies reativas e com a liberação de íons de ítria. A liberação de íons foi testada em solução salina a $37^{\circ} \mathrm{C}$ de temperatura (a $0,12 \mu \mathrm{g}$ $\mathrm{cm}^{-2}$ ) a partir de placas de material poroso de alta densidade (HIP, a $160 \mathrm{MPa}$, de $\left.1225^{\circ} \mathrm{C}, 2 \mathrm{~h}\right)$. Na solução de ácido $\left(0,02 \mathrm{M}\right.$ de ácido láctico a $\left.37^{\circ} \mathrm{C}\right)$, a ítria e os íons de zircônia aumentaram (a $3 \mu \mathrm{g} \mathrm{cm}^{2}$ ), levando à conclusão de que a cerâmica de zircônia não pode ser utilizada em ambiente ácido, como a cavidade oral.

Efeitos citotóxicos em fibroblastos L929 cultivados em PECF (fluido pseudo extra-celular), utilizado como um lubrificante em testes de desgaste, foram analisados por Ito et al. (1993). A citotoxicidade dos produtos de desgaste obtidos pelo atrito do polietileno - UHMWPE contra Y-PSZ foi maior do que a citotoxicidade dos produtos de desgaste do polietileno - UHMWPE contra o Ti-6Al-4V. A citocompatibilidade de PECF foi melhorada utilizando-se um filtro com tamanho de poro de $0,22 \mu \mathrm{m}$. Como os efeitos tóxicos não podem estar relacionados nem a libertação de íons, nem as de partículas de polietileno menores que 0,22 $\mu \mathrm{m}$ de diâmetro, as partículas amorfas flutuantes de $\mathrm{Zr}(\mathrm{OH}) 4$ sobre a superfície do meio de cultura, provenientes de atrito em PECF alcalino, pode ser considerada como uma das causas da citotoxicidade. A presença de hidróxido de zircônio pode indicar, pelo menos na opinião dos autores, a falta de estabilidade no material PSZ testado.

Dion et al. (1994), na presença de extratos de ZrO2 / Y2O3 testaram o contato indireto, a viabilidade celular e MTT em fibroblastos 3T3 e HUVEC, a fim de detectar os possíveis efeitos de produtos lançados pelos pós cerâmicos. A conclusão dos autores foi que ambas as cerâmicas e seus produtos não têm efeitos 
tóxicos sobre culturas de células também quando em contato com células do sangue.

Os efeitos tóxicos dos pós de Ca-PSZ de diversas granulometrias (30-106 $\mu \mathrm{m})$ PHA, foram avaliadas em comparação com os pós de TiO2 (BUKAT et al., 1990). O efeito inibitório foi dose dependente (a partir de 0,06 a $12 \mathrm{mg} / \mathrm{ml}^{-1}$ ). Em todas as concentrações utilizadas, os pós de Ca-PSZ apresentaram efeitos inibitórios inferiores aos pós de $\mathrm{TiO} 2$ (rutile). Mesmo em concentrações mais elevadas, o efeito inibitório nunca excedeu 50\% (LD 50\%). Essas observações foram confirmadas sucessivamente (PIANTELLI et al., 1992), quando a citotoxicidade de ZrO2-Y2O3 sobre a proliferação de linfócitos humanos foi comparada com o observado nas culturas de pós de alúmina e titânio. Todos os materiais testados (tamanho de grão $\leq 44 \mu \mathrm{m}$ ) mostrou uma inibição dose dependente sobre a proliferação dos linfócitos. A citotoxicidade da alúmina e zircônia foram similares e ambos foram menores do que a do TiO2 (rutile).

Os efeitos dos produtos de desgaste da cerâmica de alúmina e zircônia foram avaliadas usando análise de citofluorimetria de fluxo (CATELAS et al., 1996). As cerâmicas de alúmina e zircônia foram testadas em comparação com o polietileno de alta densidade sobre os macrófagos J774 e RAW267.5. Partículas de polietileno foram mais citotóxicas do que as partículas de cerâmica, mesmo quando uma quantidade menor de partículas de polietileno foram fagocitadas pelos macrófagos em relação as de cerâmica. A ausência de efeitos tóxicos de $\mathrm{ZrO} 2+2$ mol\% Y2O3, Hidroxiapatita (HAP) e alúmina em uma cultura celular de macrófagos foi também observado por outros autores (PURCHIO et al., 1995). A ausência de efeitos citotóxicos em células 3T3 de Balb e osteoblastos humanos da $\mathrm{ZrO} 2$ / 8\% de Y2O3 e HAP foi relatada (HARMAND et al., 1995). Os autores observaram diferentes níveis de sensibilidade entre os testes (em especial, o contato direto foi mais sensível que o contato indireto).

Em testes de carcinogenicidade "in vitro" (teste de Ames) e ensaios teratogenicidade (aberrações cromossómicas celulares), na presença de $\mathrm{ZrO} 2+$ Y2O3 adicionada a 0,5 ppm de UO2 foram realizados por Satoh e Niwa em 1990, que relataram resultados negativos em ambos os testes. Piconi e Maccauro (1999), 
relatou a ausência de aberração em padrões cromossómicos em células cultivadas em placas de zircônia em testes de genotoxicidade.

Poucos trabalhos têm analisado a toxicidade in vitro da zircônia. O limite da culturas de células é que, por este método, é possível analisar apenas os aspectos únicos de interação em material celular. Não é possível estabelecer segurança biológica de um único material por este método. Além disso, pode ser observado que os resultados dos ensaios in vitro são influenciadas por várias características do material, como a forma física, a superfície reativa, composição química, teor de impurezas e a distribuição. Também as condições das células durante o teste desempenham um papel importante (fibroblastos vs linfócitos PHA induzidos).

\subsection{TESTES IN VIVO}

A biocompatibilidade das cerâmicas de zircônia foi investigada in vivo por meio de implantes em osso e nos tecidos moles vários anos antes do primeiro estudo in vitro. No primeiro estudo in vivo, realizado por Helmer e Driskell (1969), peletes de zircônica densa $+6 \%$ Y2O3 foram implantados nos fêmures de macacos e os autores observaram pequena formação óssea na superfície dos peletes sem a presença de reações teciduais adversas. Hulbert et al. em 1972 implantaram discos e tubos de $\mathrm{CaO}+\mathrm{Al} 2 \mathrm{O} 3, \mathrm{CaO}+\mathrm{TiO} 2, \mathrm{CaO}+\mathrm{ZrO} 2$, como materiais porosos com uma dimensão de poros variando de $45-150 \mu \mathrm{m}$ e com materiais não porosos, nos músculos de coelhos. A análise histológica de todos os materiais testados nove meses após a implantação não revelou sinais de efeitos tóxicos, imunológicas ou carcinogênicos.

Os resultados promissores obtidos nos primeiros estudos sobre reações biológicas à zircônia, juntamente com os primeiros resultados positivos em testes de desgaste e propriedades mecânicas, fez com que vários laboratórios de pesquisa se interessassem diretamente pela zircônia. Testes de biocompatibilidade in vivo foram realizados utilizando alúmina como cerâmica de referência bioinerte e HA. Os primeiros resultados desta comparação foram contraditórios: Wagner (1987) observou após a implantação das cerâmicas de alúmina e zircônia em fêmur de 
ratos, que não ocorreu diferenças quanto a reação óssea, enquanto que Kumar et al. (1989) observaram diferenças na neoformação óssea após a inserção de Y-TZP, alúmina e hidroxiapatita em fêmur de coelhos. Seus resultados não mostraram processo inflamatório ou osteólise. Ocorreu direta aposição óssea sobre a Y-TZP, porém, foi inferior ao da alúmina. Os autores observaram o papel crítico exercido pelo local de implantação em relação a resposta do osso, devido a capacidade dos diferentes níveis de tensão e distribuição induzir a osteogênese em torno de materiais inertes relatados (KUMAR et al.,1989). Em 1989, Christel e colaboradores publicaram um importante estudo sobre os efeitos in vivo da cerâmica de zircônia. Cilindros Y-PSZ foram implantados nos músculos paravertebrais de ratos em comparação com a alúmina. Depois de 1 a 12 semanas após a operação, não foram observadas diferenças significativas entre os materiais. Resultados comparáveis foram obtidos após a implantação óssea em ratos e coelhos. Kohal et al., em 2009, também não viram diferenças histológicas ou biomecânicas entre implante de zircônia e titânio.

Reações in vivo para a cerâmica de Ca-PSZ também foram analisadas por Maccauro et al. em 1992 onde os cilindros de cerâmica foram inseridos na metáfise proximal da tíbia de coelhos. Um mês após a cirurgia, o tecido conjuntivo estava presente na interface cerâmica óssea, no entanto de 1 ano após a implantação da cerâmica, contato direto com o osso foi observado por Specchia et al. (1999). Nem reação adversa local ou sistêmica nem carcinogênese foram observadas após a injeção intraperitoneal de pós de Ca-PSZ em ratos (MACCAURO et al., 1992).

Pode-se observar, a partir dos resultados existentes na literatura, que não há um consenso geral sobre a ausência de efeitos tóxicos locais ou sistêmicos após a implantação de zircônia cerâmica nos músculos ou ossos de diferentes animais, nem após a injeção de pó em camundongos. Durante os testes, especialmente na fase de pós-operatório, o tecido conjuntivo é frequentemente observado na interface osso-cerâmica.

Os resultados dos ensaios in vivo, realizados em diferentes modelos animais, nunca mostraram efeitos adversos, apesar das diferenças entre os materiais, da forma das amostras, do local de implantação e do método de avaliação selecionada. Vários autores (GARVIE et al., 1984; MACCCAURO et al., 1992; SPECCHIA et al., 
1992; GRECO et al., 1993) têm observado contato direto do osso com a cerâmica, no entanto, na fase inicial, o tecido conjuntivo estava presente na interface. A origem deste tecido, que desempenha um papel importante na distribuição de tensões na fase precoce da resposta do osso, está relacionado com as tensões de cisalhamento que se originam na interface entre um material e um tecido (cerâmica e osso) com diferentes módulos de Young (RADIN et al., 1986). Além disso, de acordo com Chang e colaboradores (1996), a resposta metabólica do osso em relação a cerâmica pode ser influenciada pelo local do implante, devido à atividade osteogênica da cavidade medular ser muito baixa quando comparada com a do periósteo e endósteo. Vale a pena observar que os locais de implantação e modelos animais podem induzir diferentes respostas relacionadas à transmissão de diferentes estresses.

Pelo discutido, percebesse que existe um crescente interesse na utilização de cerâmicas e materiais alternativos ao titânio. No entanto, alguns pontos sobre a diferença de comportamento desses materiais in vivo ainda permanecem sem adequada fundamentação. Nesse sentido, trabalhos com ferramentas de análises mais precisas são recomendados para entender o comportamento de materiais a base de zircônia reforçada com ítria, in vivo. 
2 PROPOSIÇÃO 



\section{PROPOSIÇĀO}

Avaliar "in vivo" a osseointegração de implantes produzidos em zircônia reforçada com ítria (Y-TZP) e compará-las com o implante de titânio usinado e com as de superfície jateada com brushita.

\subsection{ESPECIFICAMENTE PRETENDEMOS:}

1) Quantificar a formação óssea temporal por meio de marcadores incorporados durante o processo de mineralização óssea ao microscópio confocal;

2) Avaliar a osseointegração ou aposição de tecido mole na superfície dos implantes pela análise histológica dos cortes corados pelo azul de toluidina;

3) Quantificar o percentual de contato ósso/implante (BIC) e de formação óssea (BA) a $400 \mu \mathrm{m}$ de distância ao redor dos implantes. 




\section{MATERIAIS E MÉTODOS}

\subsection{IMPLANTES}

Neste estudo foram utilizados 40 implantes, sendo 20 cerâmicos (Grupo Experimental I - GE-1), 10 em titânio (Grupo Controle - GC), ambos com superfície lisa (sem tratamento de superfície) e com as mesmas medidas: diâmetro externo = $3,75 \mathrm{~mm}$ e comprimento do ápice à cabeça $=10,0 \mathrm{~mm}$ e 10 implantes em titânio de formato cônico e com tratamento de superfície (Grupo Experimental II - GE-2), com diâmetro externo $=4,5 \mathrm{~mm}$ e $10 \mathrm{~mm}$ decomprimento do ápice a cabeça. Os implantes foram acondicionados em envelopes autoselantes, identificados e esterilizados por radiação gama (25KGy), pela empresa EMBRARAD -Jarinu- SP Brasil.

\subsection{ANIMAIS, ANESTESIA E MEDICAÇĀO}

O projeto foi submetido e aprovado pelo Comitê de Ética no Ensino e Pesquisa em Animais da Faculdade de Odontologia de Bauru-USP. Processo número 06/2010 (Anexo 1).

Vinte coelhos adultos, brancos, da espécie Nova Zelândia (Oryctolagus cuniculus), sendo 10 machos e 10 fêmeas com peso aproximado de $4,0 \mathrm{Kg}$ foram selecionados para este experimento. Os animais foram obtidos na Faculdade de Medicina Veterinária e Zootecnia - UNESP, de Botucatu-SP. No dia anterior à intervenção cirúrgica, como terapia preventiva, foi administrado o antibiótico Enrofloxacino $10 \% \quad(0,5 \mathrm{ml} /$ animal $)$ e 0 antiinflamatório Maxican $0,2 \% \quad(0,02$ $\mathrm{ml} /$ animal); medicações essas que foram administradas por mais 06 dias no pós operatório. Para os procedimentos cirúrgicos, coube a cada animal como medicação intramuscular: Cloridrato de Ketamina (DOPALEN® - Vetbrands / Brasil - 0,45 $\mathrm{ml} / \mathrm{Kg}$ ) como anestésico geral, Cloridrato de Xilasina (ANASEDAN® - Vetbrands / Brasil - 0,32 $\mathrm{ml} / \mathrm{Kg}$ ) como sedativo, relaxante muscular e analgésico e Acepromazina (ACEPRAN® 1\% - Univet - dosagem 0,05 ml/Kg) como neuroléptico e 
tranqüilizante. Com esta dosagem, os animais permaneceram sob profunda narcose durante 90 a 120 minutos. Para se conseguir hemostasia local um anestésico local, foi aplicado nas áreas cirúrgicas $0,8 \mathrm{ml}$ de Cloridrato de Prilocaína-Felipressina a 3\% (Citanest-Astra, México).

\subsection{PROTOCOLO EXPERIMENTAL}

\subsubsection{Instalação dos Implantes:}

Como protocolo experimental, os coelhos receberam os implantes aleatóriamente evitando-se apenas a colocação de implantes iguais no mesmo animal (Figura 7). A posição de instalação na tíbia foi a proximal (mais próxima à articulação do joelho). Os implantes permaneceram instalados durante um período de oito semanas. 


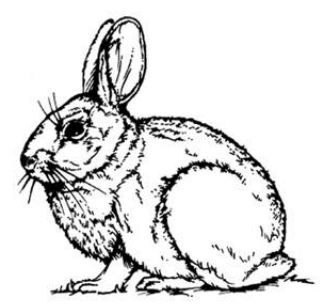

20 Coelhos Nova Zelândia

(Oryctolagus cuniculus)

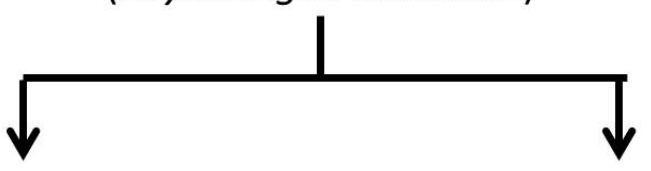

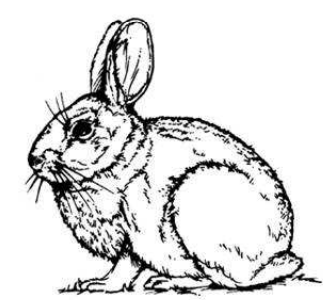

10 Machos

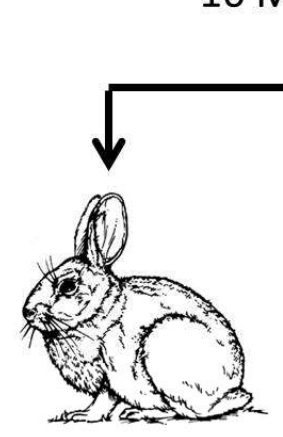

Lote $1(n=5)$

D1: GE-1

D2: GC

$\downarrow$

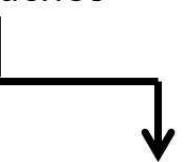

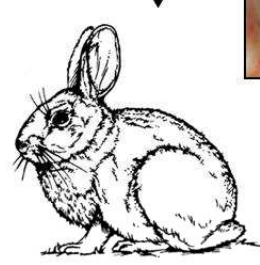
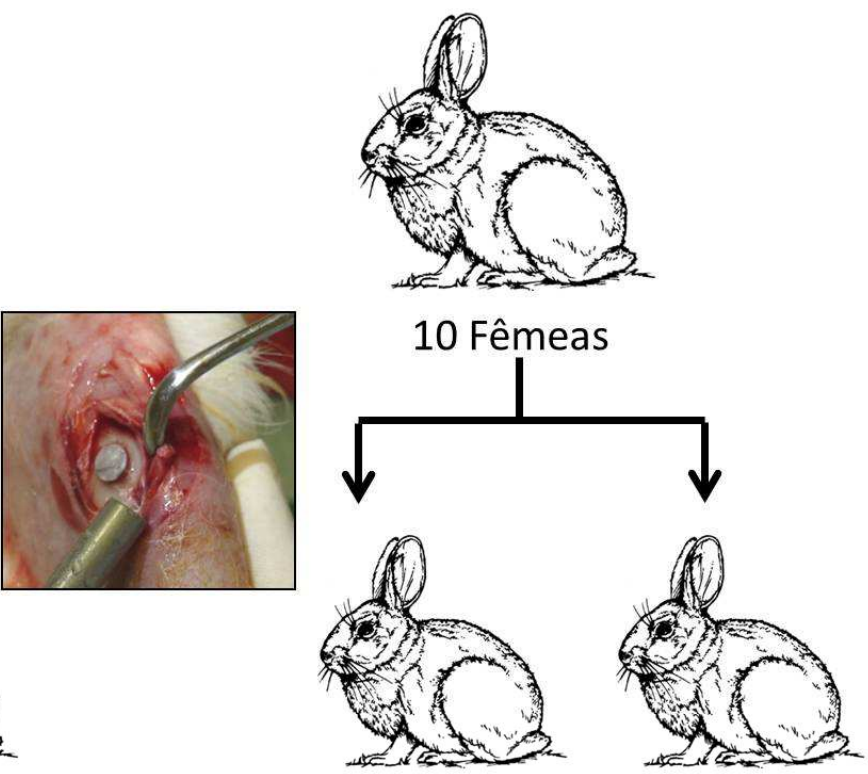

Lote $3(n=5) \quad$ Lote $4(n=5)$

Lote 2 ( $n=5)$

D1: GE-1

D1: GE-1

D1: GE-1

D2: GC

D2: GE-2
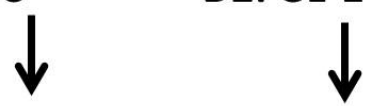

Marcação com fluorocromos (Tetraciclina, Alilzarina e Calceína) e análise ao microscópio confocal

Avaliação morfológica da formação óssea e determinação do BIC e BA em cortes de tecido duro corados pelo azul de toluidina

Figura 7 - Cronograma de utilização dos animais e randomização para instalação dos implantes nos diferentes grupos 


\subsubsection{Procedimentos cirúrgicos para instalação dos implantes:}

Campos cirúrgicos estéreis foram utilizados para delimitar a área da intervenção. A região cirúrgica recebeu tricotomia prévia, seguida de antissepsia local com iodo tópico e infiltração de anestésico local (Citanest $3 \%$ com octapressin ( - Dentsply) (Figura 8a). Uma incisão com extensão de aproximadamente $5,0 \mathrm{~cm}$ foi realizada logo abaixo da articulação do joelho, longitudinalmente em relação à tíbia, envolvendo pele e periósteo; os tecidos foram divulsionados por meio de divulsão romba utilizando-se de um descolador de Molt para acesso ao tecido ósseo (Figura 8b). As lojas cirúrgicas foram confeccionadas pela sequência de brocas indicadas pelos fabricantes dos implantes (Figura 8c). A velocidade de perfuração foi fixada em $1500 \mathrm{rpm}$, sob intensa irrigação com soro fisiológico e o motor de perfuração e instalação teve seu torque de insersão limitado à $40 \mathrm{~N}$ (Figura 8d). Uma vez instalado o implante, o intermediário pré fragilizado foi removido com auxílio de uma broca diamantada em alta rotação (Figura 8e). Após a remoção do intermediário a superfície foi planificada com auxílio de uma broca diamantada de grão fino (Figuras 8f-g). Em seguida os tecidos moles foram reposicionados e fechados por planos (inicialmente o periósteo e finalmente a pele) com pontos isolados e fio de seda (Figuras $\mathbf{8 h}$ ). O local suturado ainda recebeu aplicação do mesmo iodo tópico utilizado na antissepsia inicial. 

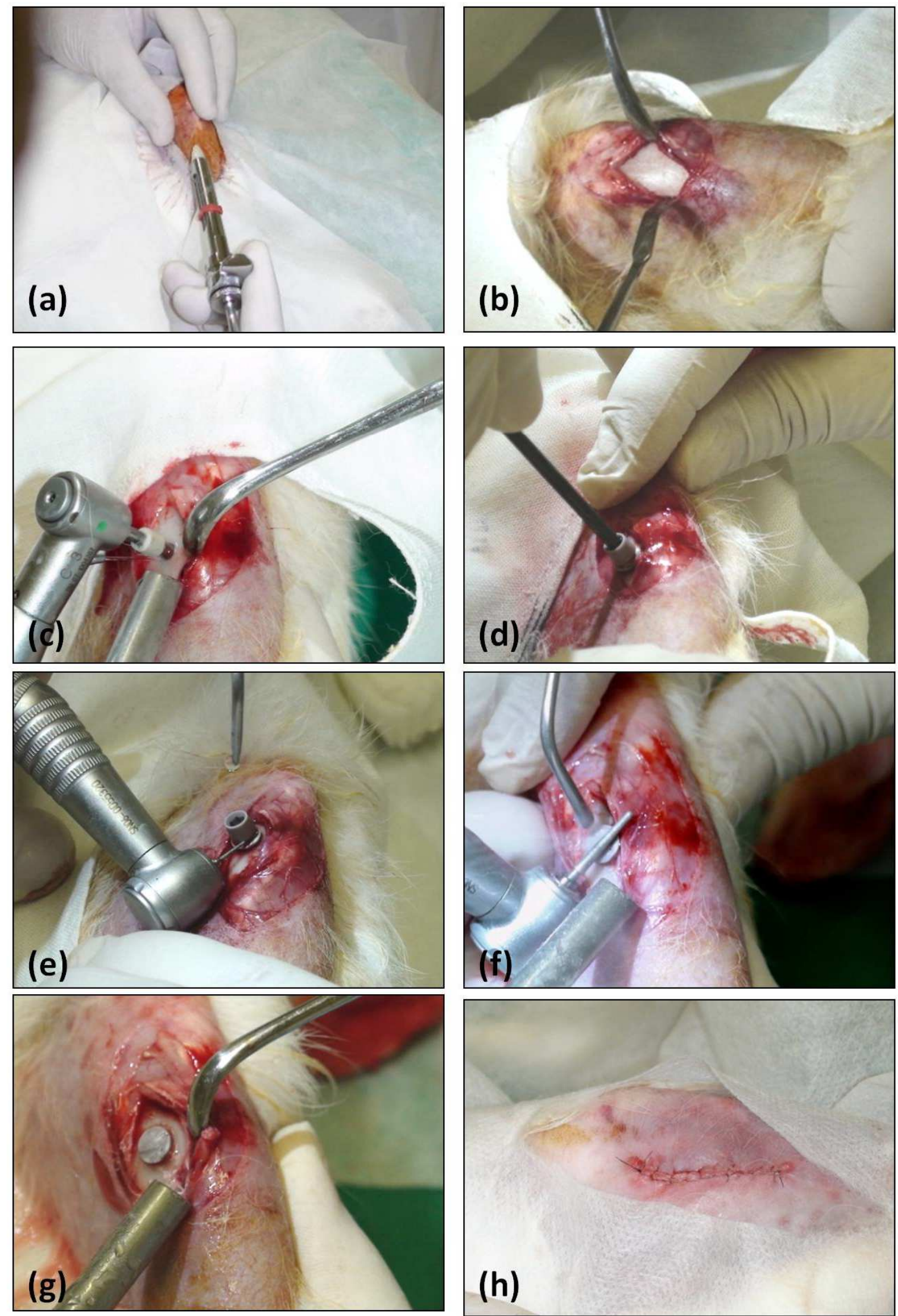

Figura 8 - Procedimentos cirúrgicos: a) aplicação de anestésico local; b) Incisão do tegumento; c) exposição da tábua óssea e perfuração; d) instalação do implante; e) remoção do intermediário do implante $\boldsymbol{f}$-g) alisamento da superfície do implante; $\boldsymbol{h}$ ) reposição e sutura do retalho. 

3.3.3 Administração pós-cirúrgica dos marcadores de neoformação óssea para análise ao Microscópio Confocal.

Durante o período de cicatrização de oito semanas foram administrados marcadores ósseos de união à apatita nos tecidos subcutâneos para determinar o processo de formação óssea pós-operatório, bem como para quantificar a deposição óssea em área na interface enxerto/tecido remodelado. Para a aplicação, os marcadores em forma de pó foram pesados em balança analítica (METTLER TOLEDO AT261-Delta Range) com precisão de 0,01 mg e diluídos em soro fisiológico e solução tampão de $\mathrm{NaHCO}_{3}$. Iniciando no 14ํㅡㅁ dia após a cirurgia, os animais receberam semanalmente injeção subcutânea de marcadores fluorescentes - tetraciclina (Teuto - Brasil - 25mg/Kg), alizarina (Merck - Brasil 30mg/Kg) e calceína (Merck - Alemanha 20 mg/Kg) de acordo com a descrição:

Tabela 1 - Seqüência de injeção dos marcadores fluorescentes

\begin{tabular}{ccc}
\hline PÓS-CIRURGIAS (dias) & MARCADOR & INJETADO (mg/kg) \\
\hline $\mathbf{1 4}$ & Tetraciclina & 25 \\
$\mathbf{2 1}$ & Tetraciclina & 25 \\
$\mathbf{2 8}$ & Alizarina & 30 \\
$\mathbf{3 5}$ & Alizarina & 30 \\
$\mathbf{4 2}$ & Calceína & 20 \\
$\mathbf{4 9}$ & Calceína & 20 \\
56 & Eutanásia & - \\
\hline
\end{tabular}

\subsubsection{Eutanásia dos animais, coleta e fixação das peças anatômicas}

Os animais foram eutanasiados por overdose anestésica com as mesmas drogas utilizadas para os procedimentos cirúrgicos. As peças anatômicas foram removidas com aproximadamente $3,0 \mathrm{~cm}$ deixando um coto ósseo de 1,0 cm em cada extremidade e serão fixadas em formol a 10\% tamponado por 24 horas. 
3.3.5 Processamento das peças para inclusão em resina Technovit 7200VLC

a) Coleta e inclusão na resina technovit: Os tecidos moles foram dissecados e um bloco, contendo os enxertos, foi removido por meio de serra manual e mantido imerso em solução neutra de formol a 10\% durante 30 dias. Após a fixação, as amostras foram lavadas em água corrente por 12 horas. A desidratação e infiltração/inclusão na resina foram realizadas sob agitação (Figura 9a). As peças foram desidratadas em diferentes soluções de etanol por períodos consecutivos de 24 horas de acordo com a Tabela 2.

Tabela 2 - Série de álcoois para a desidratação

\begin{tabular}{cc}
\hline Sequência & Concentração \\
\hline $\mathbf{1}$ & $70 \%$ \\
$\mathbf{2}$ & $80 \%$ \\
$\mathbf{3}$ & $90 \%$ \\
$\mathbf{5}$ & $96 \%$ \\
\hline
\end{tabular}

Após a desidratação, as amostras permaneceram em agitador (EXAKT 510 DEHYDRATION AND INFILTRATION SYSTEM - IKA SCHUETTLER 510 HS 501 DIGITAL) com diferentes concentrações de resina plástica Technovit 7200 VLC (HERAEUS KULZER GmbH, Wehrhein, Germany) dissolvida em álcool absoluto (etanol) para infiltração desta solução no interior da cavidade medular dos blocos ósseos. A Tabela 3 mostra as diferentes soluções utilizadas durante o procedimento de embebição. 
Tabela 3 - Procedimento de embebição

\begin{tabular}{cc}
\hline Solução & Tempo sequencial (h) \\
\hline 30\% Technovit + 70\% Etanol & 72 \\
50\% Technovit + 50\% Etanol & 72 \\
70\% Technovit + 30\% Etanol & 72 \\
100\% Technovit & 72 \\
100\% Technovit & 72 \\
\hline
\end{tabular}

Após este procedimento, as amostras foram incluídas em recipientes apropriados, com os enxertos estáveis na parte inferior do recipiente e o longo eixo paralelo ao plano horizontal (Figura 9b). Os recipientes foram preenchidos com resina plástica Technovit 7200 VLC, colocados em vácuo Plate Degasser PD3 (Edwards) por 12 horas para uma melhor penetração da resina nos espaços medulares e mantidos em equipamento para polimerização da resina (EXAKT 520 LIGHT POLYMERIZATION UNIT) permanecendo 4 horas sob luz branca e 4 horas sob luz azul.

b) Obtenção dos cortes, desgaste e fixação na lâmina: As amostras, após completa polimerização da resina, foram retiradas dos recipientes e desgastadas de acordo com a angulação do implante para poder obter cortes longitudinais. Os blocos foram aderidos às lâminas de acrílico com adesivo (Technvit 7230) e polimerizados em luz azul por 15 min com fotopolimerizador acoplado a uma máquina de vácuo para posicionamento da lâmina e seccionadas no sistema EXAKT (EXAKT 310 BAND SYSTEM) por meio fita impregnada com micropartículas de diamante e bornita (Exakt - D64) (Figuras 9c-d), refrigerada por jato de água, velocidade controlada e com carga aplicada de $200 \mathrm{~g}$. De cada amostra foram realizadas quatro cortes do longo eixo do implante com $700 \mu \mathrm{m}$ de espessura. Estes cortes foram colados em lâminas de acrílico utilizando resina Technovit 7230 VLC (KULZER \& Co, Wehrhein, Germany) polimerizadas em equipamento de prensagem adesiva de precisão (EXAKT 401 VACUUM ADHESIVE PRESS). Estas lâminas foram lixadas e polidas em politriz (EXAKT 400 CS MICRO GRINDING SYSTEM) (Figura 9e) utilizando lixas de carbeto de silício com granulações 500, 800, 1000, 1200, 2000, 2400 e 4000 mesh para ajustar a espessura em $30 \mu \mathrm{m}$. 

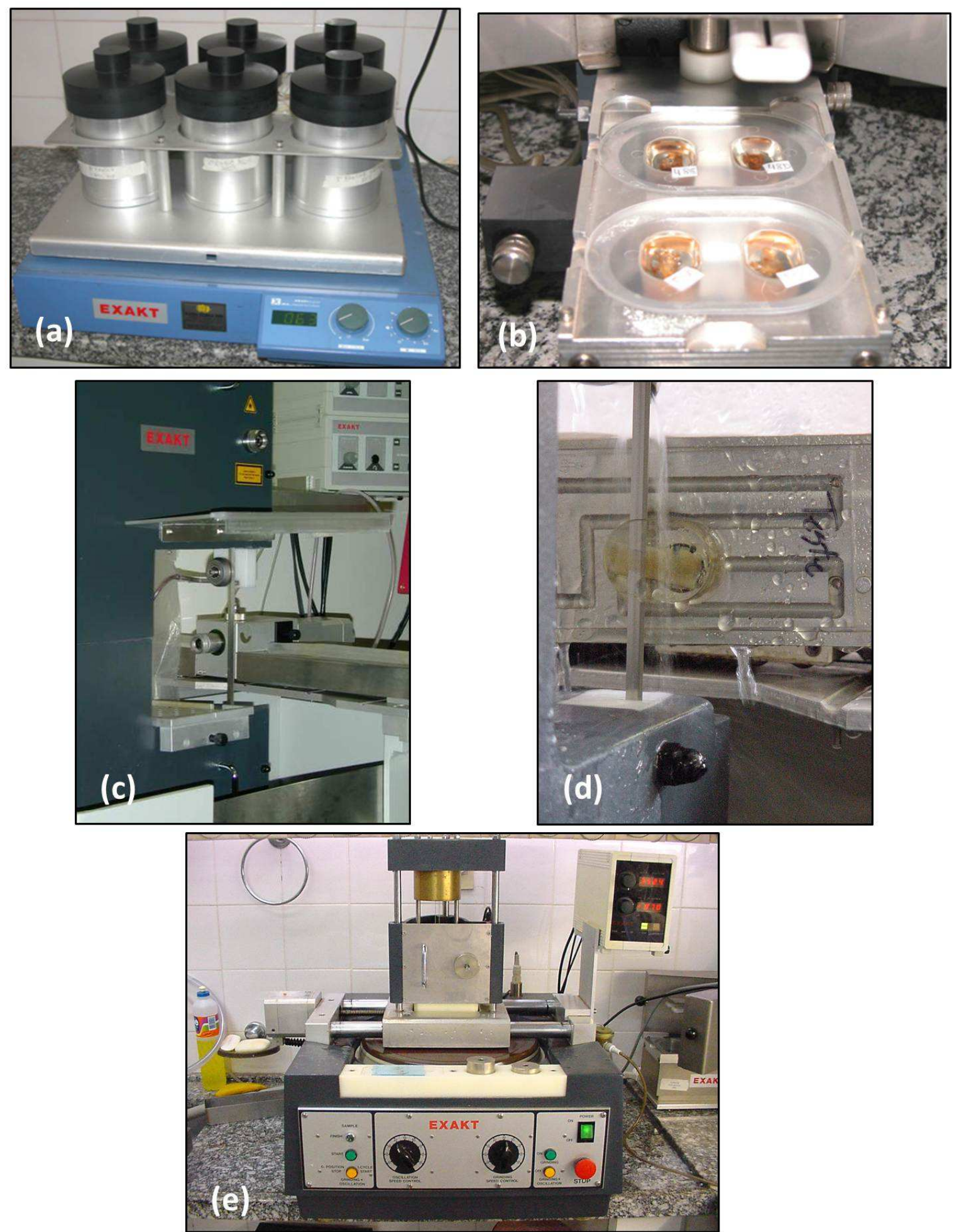

Figura 9 - Sistema Exakt utilizado para obtenção dos cortes: a) mesa agitadora utilizada durante a desidratação e infiltração da resina; b) inclusão e polimerização das peças; $\boldsymbol{c}$-d) obteção dos cortes histológicos; e) desgaste e polimento dos cortes. 

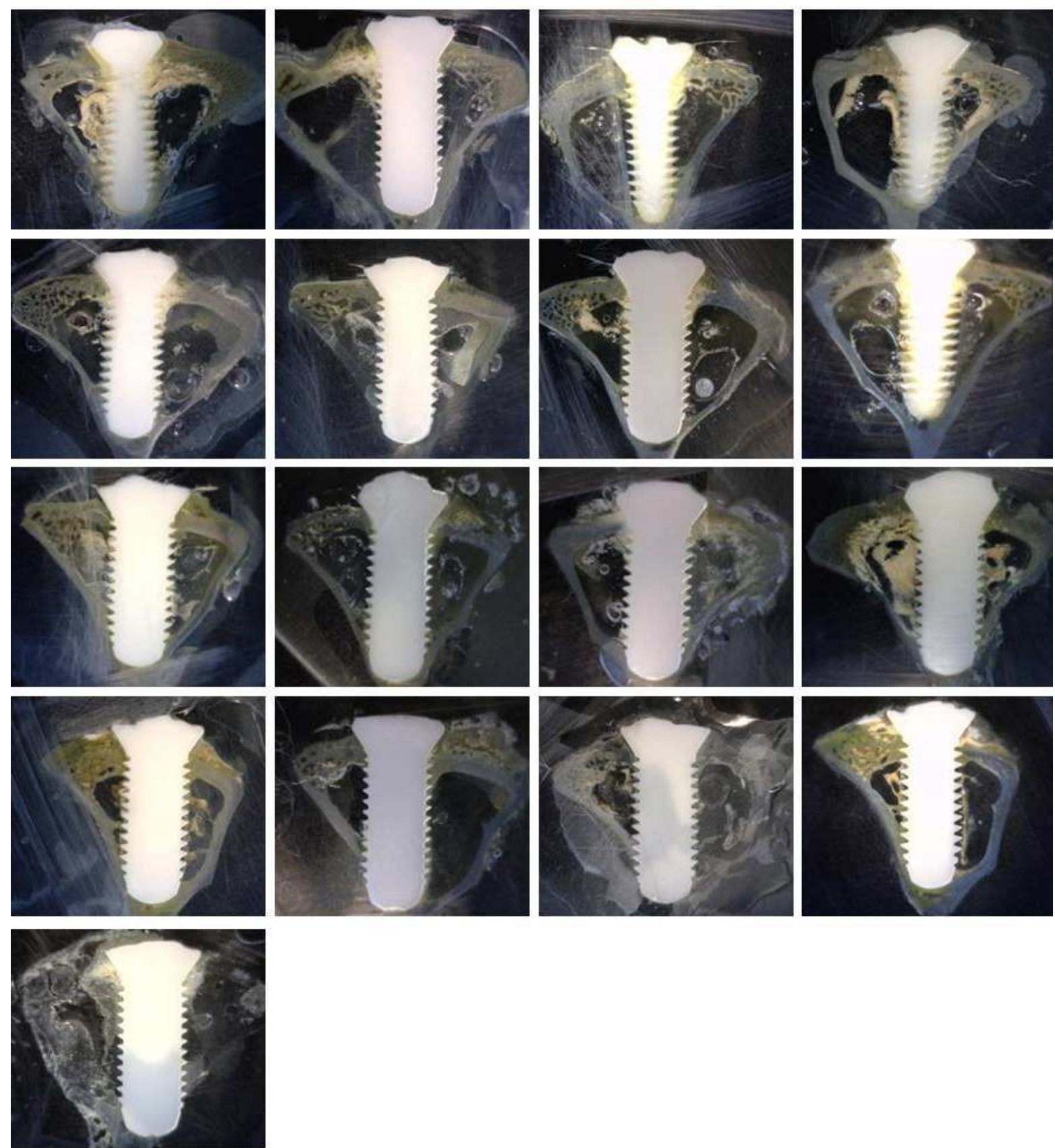

Figura 10a - Fotos dos cortes obtidos dos representantes do Grupo Experimental 1 (GE-1 - implantes cerâmicos) com espessura de 60 $\mu \mathrm{m}$ em fase final de desgaste e polimento 


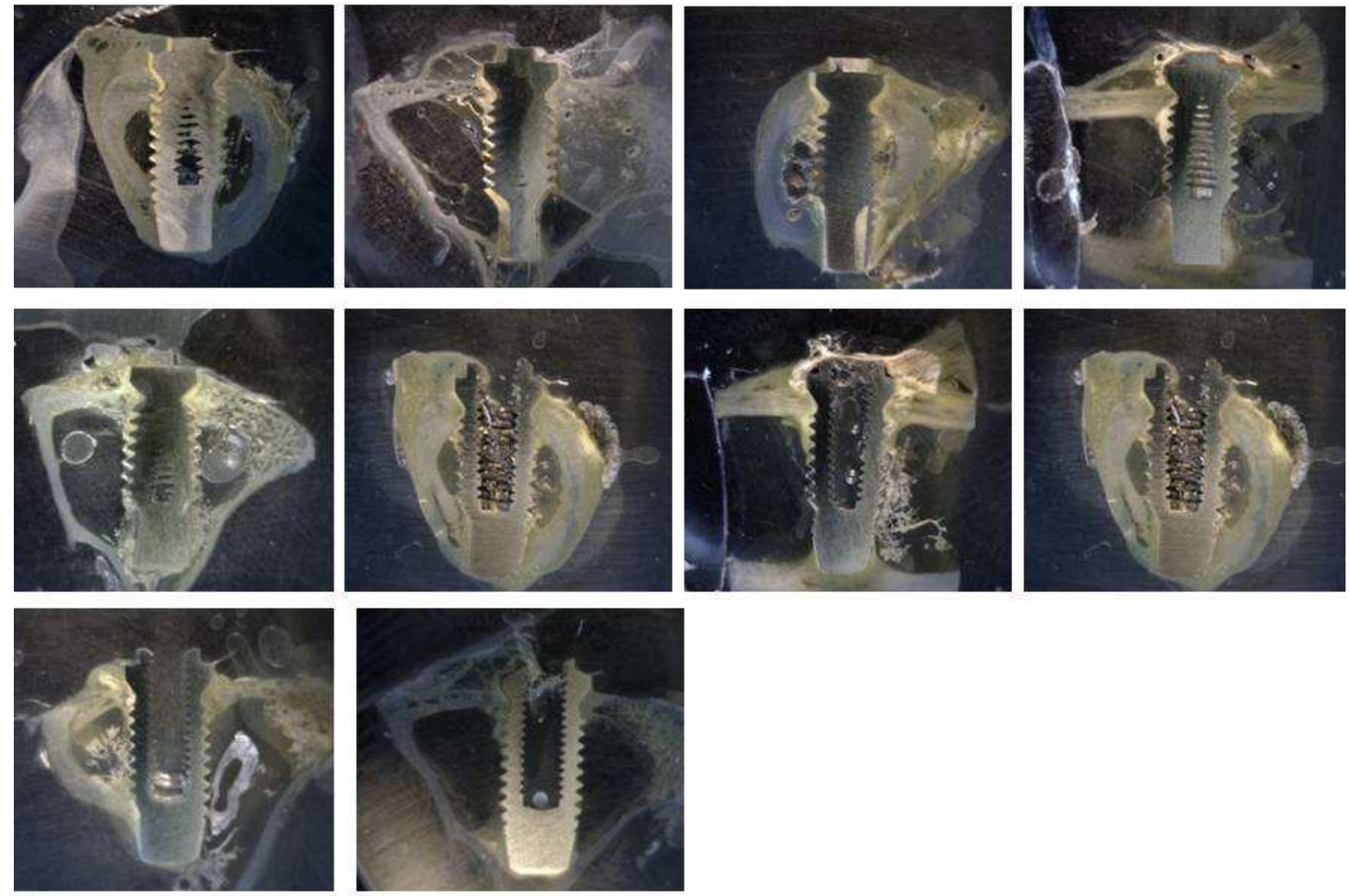

Figura 10b - Fotos dos cortes obtidos dos representantes do Grupo Controle (GC - implantes de titânio sem tratamento de superfície) com espessura de $60 \mu \mathrm{m}$ em fase final de desgaste e polimento
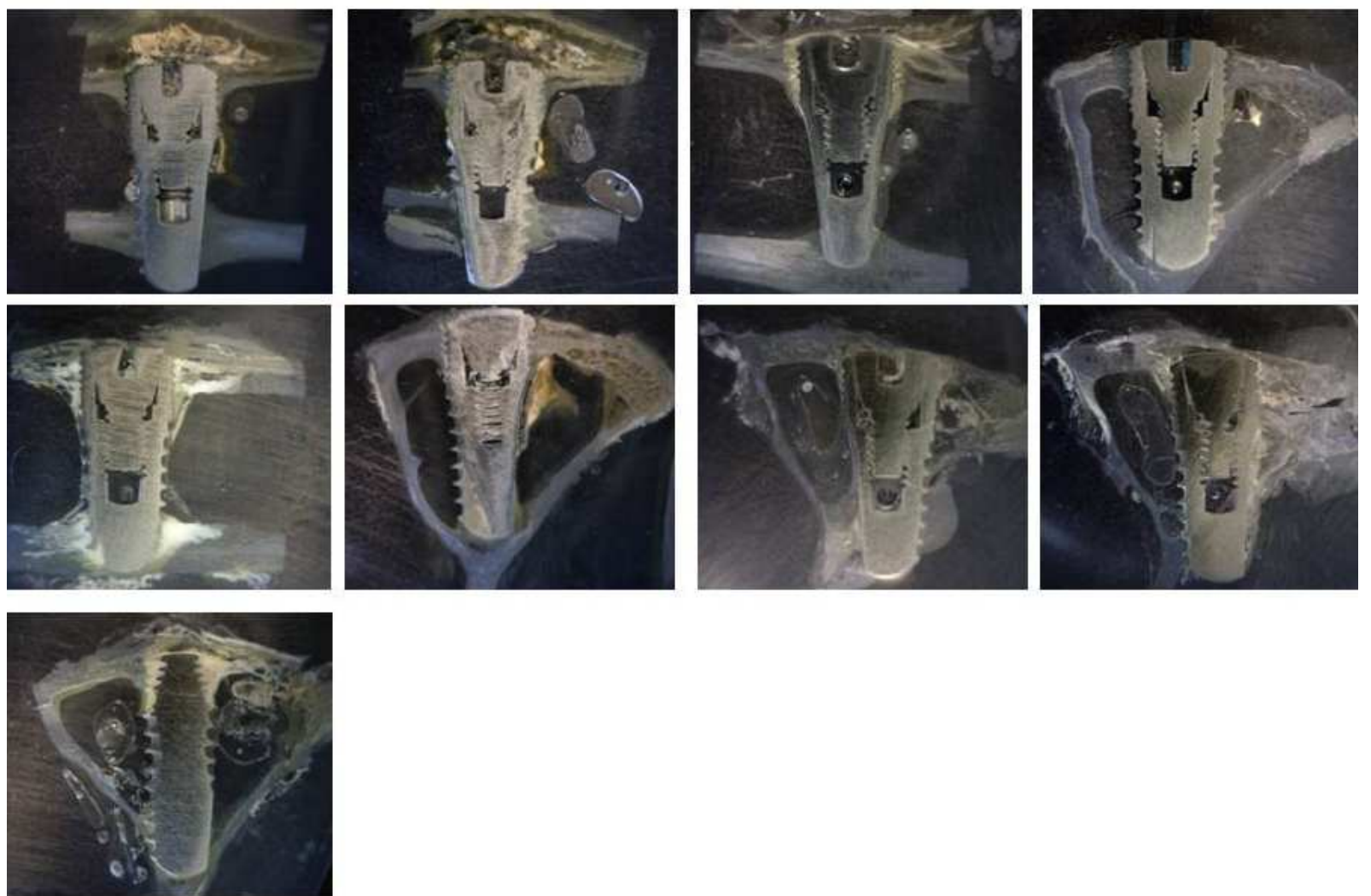

Figura 10c - Fotos cortes obtidos dos representantes do Grupo Experimental 2 (GE-2 - implantes de titânio com superfície tratada) com espessura de $60 \mu \mathrm{m}$ em fase final de desgaste e polimento 



\subsubsection{Análise histomorfométrica com o microscópio confocal:}

Por meio da utilização da fluorescência dos marcadores, os espécimes foram analisados em microscópio confocal Leica TSS SPE (Mannheim Alemanha) (Figura 11b) antes das lâminas terem sido coradas.

Foram selecionados 2 cortes mais centrais de cada amostra/implante para esta análise. De cada corte histológico foram selecionadas 4 áreas distintas da superfície do implante para a análise: região cortical em contato com as duas roscas iniciais próximas a cabeça do implante (região 1A-direito e 1B-esquerdo) e região medular em contato com as roscas subsequentes (região 2A-direito e 2B-esquerdo) (Figura 11a), com objetiva de 10x, espessura de análise de $20 \mu \mathrm{m}$ com seccionamento óptico a cada $1 \mu \mathrm{m}$, sempre numa posição padronizada, onde apareciam 2 roscas. Utilizou-se para análise fluorescências para tetraciclina (faixa espectral cinza), alizarina (faixa espectral vermelho) e calceína (faixa espectral verde) e também uma imagem em overlay com superposição dos 3 marcadores (Sequência na Figura 12).
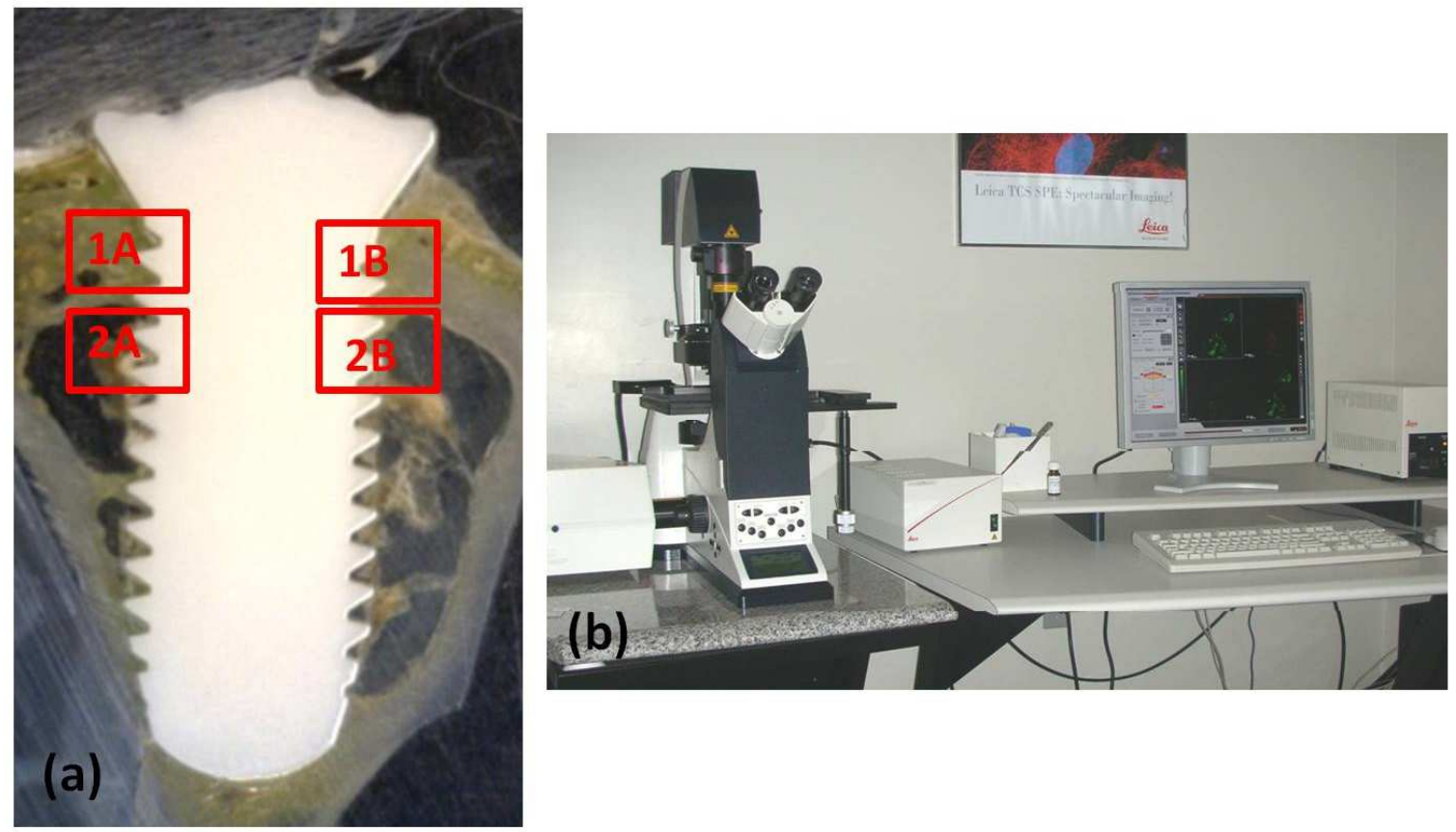

Figura 11 - Obtenção das imagens no Confocal: a) Padronização dos campos os quais foram obtidas as imagens; e b) microscópio confocal Leica TSS SPE onde foram obtidas as imagens 



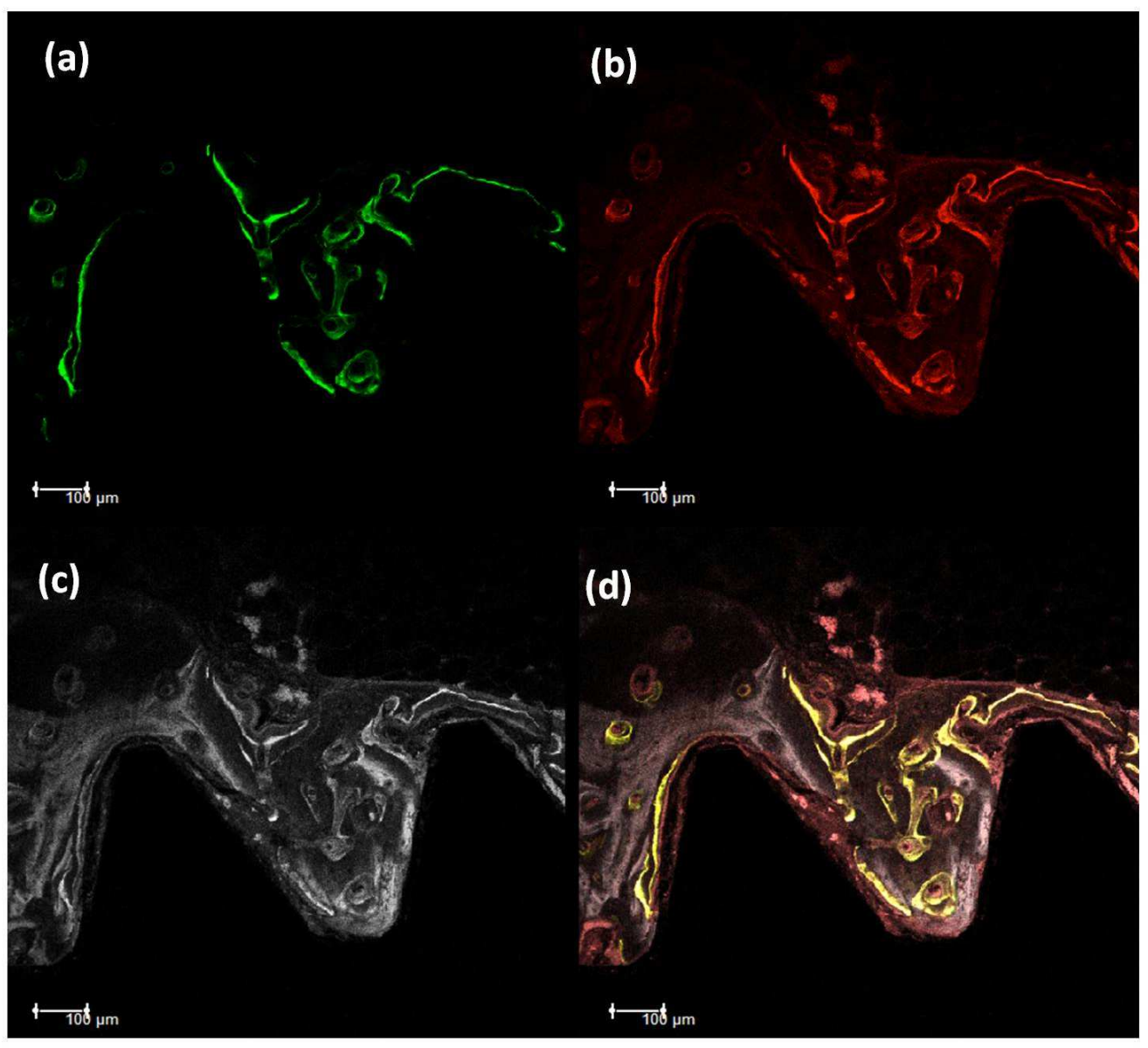

Figura 12 - Imagem obtida no microscópio confocal a) Calceína, b) Alizarina, c) Tetracilina e d) Overlay

Para análise histomorfométrica da marcação utilizou-se o software AxioVision 4.8.2 (Carl-Zeiss Micro Imaging GmbH - Alemanha). Primeiramente, determinou-se a área a ser analisada em pixel $^{2}$ (Figura 13a) para depois determinar o total de área marcada (Figura 13b). Para cada marcador e o overlay foram determinados os padrões RGB (Figura 14). De cada peça foram determinados o percentual de cada marcação (para cada intervalo de tempo, conforme o marcador) e do overlay (total de tecido ósseo neoformado). Subsequentemente os dados serão submetidos a testes estatísticos. 


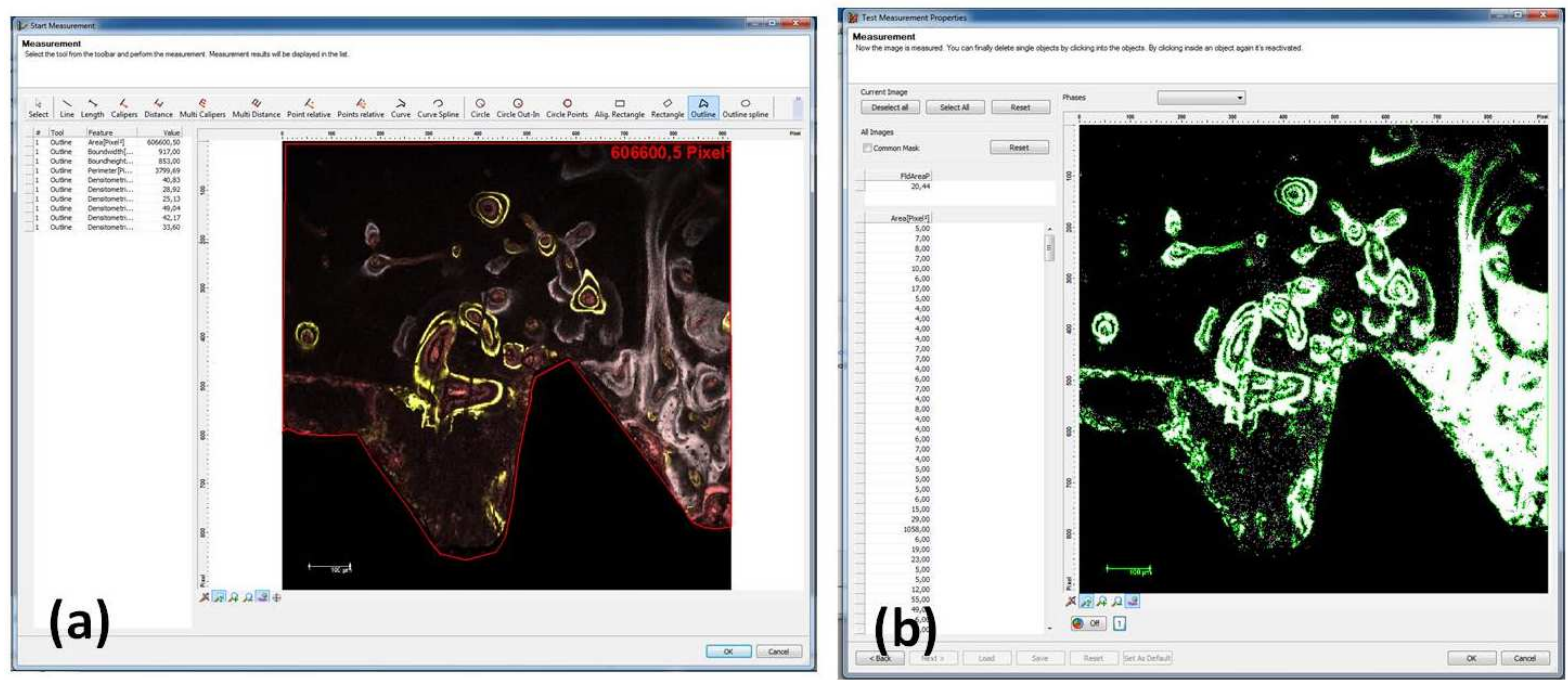

Figura 13 - Programa Axion Vision para determinação do total de área marcada: a) determinação da área de interesse; b) quantificação em pixel da área marcada.
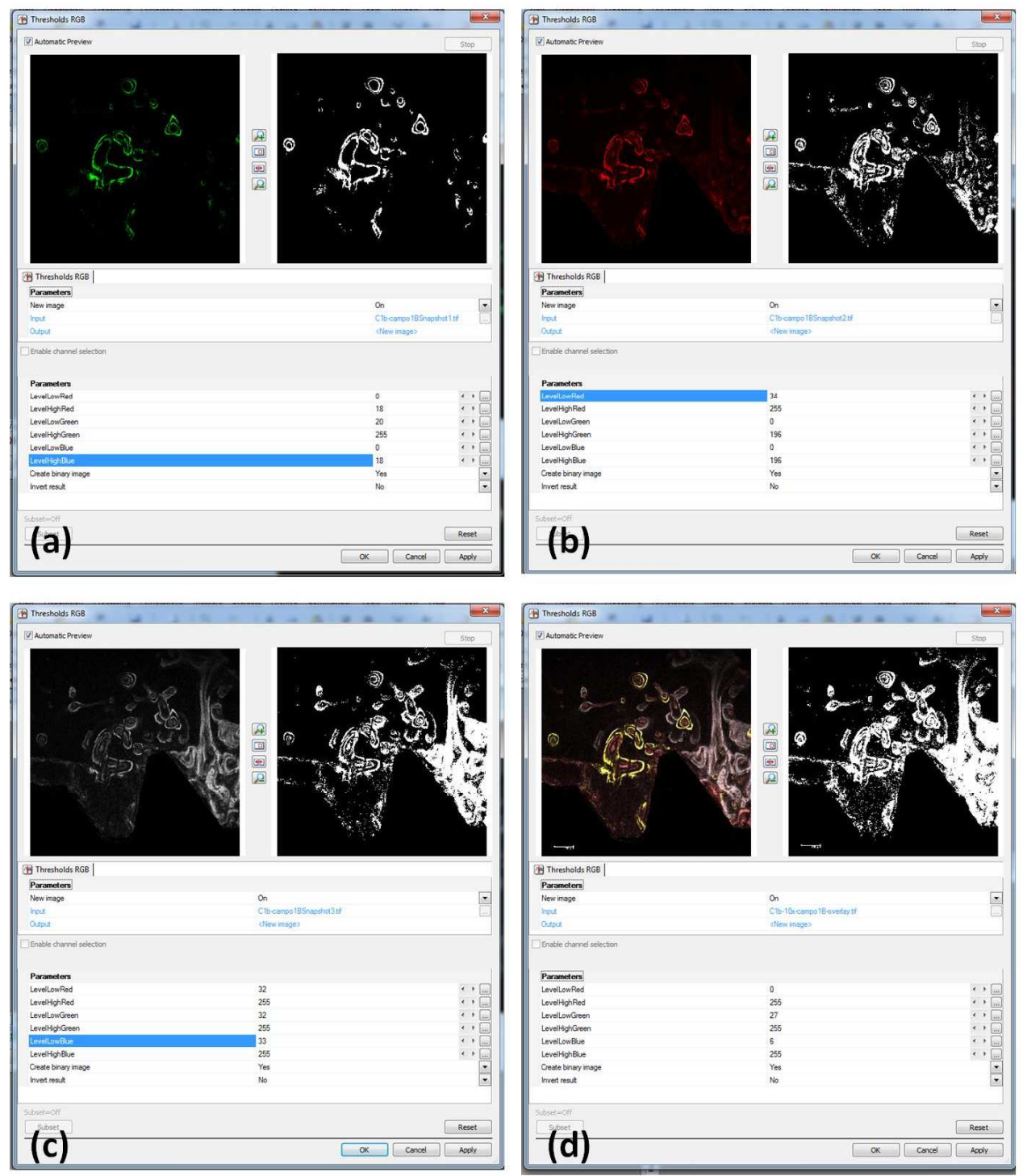

Figura 14 - Programa Axion Vision para determinação da área total. Parametros RGB utilizados para Calceína (a), Alizarina (b), Tetraciclina (c) e Overlay (d). 


\subsubsection{Cortes com 30 micrometros de espessura corados pelo Azul de} toluidina para determinação do percentual de contato osso implante - BIC e percentual de tecido ósseo ao redor do implante - BA

Com o término do desgaste e polimento dos cortes teciduais de cada amostra, os cortes foram corados com azul de toluidina especial para as amostras incluidas na resina acrílica, composta de tetraborato de sódio, pironina $\mathrm{G}$ e azul de toluidina dissolvidos em água destilada. A análise microscópica dos implantes foi realizada com auxílio do microscópio AXIOSCOP 2 (Carl Zeis) e do software AxioVision (Carl Zeiss). Os critérios para análise de osseointegração foram:

a) percentual de contato osso e implante (BIC): com auxílio do programa foram obtidas medidas lineares da região do implante em contato com o

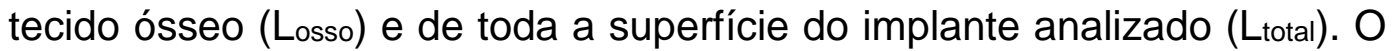
BIC foi calculado pela seguinte fórmula BIC $=\left(\operatorname{Losso}_{0} 100\right) / L_{\text {total }}$.

b) percentual de tecido ósseo ao redor do implante: no programa determinamos a área total entre as roscas $\left(A_{\text {total }}\right.$ e a área ocupada pelo tecido ósseo (Aosso), o BA foi calculado pela seguinte relação: $B A=$

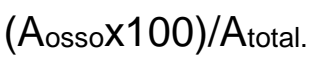

\subsection{ANÁLISE ESTATÍSTICA}

Todos os dados numéricos foram submetidos ao teste de normalidade (Kolmogorov-Smirnov) e de homocedasticidade (Bartlet). Os dados ponderais de massa corporal no dia da implantação e 56 dias após foram confrontados entre sí pelo test "t" pareado. Todos os resultados referente ao percentual de marcador ósseo e do overlay, bem como do BIC e do BA, foram submetidas ao teste de MannWhitney para comparação entre sexo e pela análise de variância (ANOVA) a um critério para a comparação entre grupos, sendo as médias contrastadas pelo teste de Tukey, usando software Statistica 7 (StatSoft Inc., Tulsa, Oklahoma, EUA) para Windows, com um nível de significância de 5\%. 


\section{RESULTADOS}





\section{RESULTADOS}

\subsection{DADOS CLÍNICOS E PONDERAIS}

Os animais oriundos da Faculdade de Medicina Veterinária e Zootecnia UNESP, de Botucatu-SP chegaram ao Biotério Central da FOB com idade de 4 meses e pesando em média $3,5 \mathrm{Kg}$. Os animais foram alocados em gaiolas individuais com alimentação sólida (ração Purina®) e líquida ad libitum. Durante o período de adaptação ou quarentena os animais se alimentaram normalmente e não foi observada nenhuma alteração comportamental ou da pele/pelagem. No dia das cirurgias os animais pesavam em média 4,18 Kg, não havendo diferenças entre os grupos (Tabela 4). Embora as massas corporais dos animais não apresentassem diferenças significativas entre os sexos, às fêmeas eram visivelmente menores no tamanho, porém, eram mais obesas. Durante a anestesia geral e os procedimentos cirúrgicos não ocorreu intercorrência alguma e todos os implantes foram inseridos sem qualquer problema transoperatório. Porém, como os ossos das fêmeas eram estruturalmente menores, o torque na instalação dos implantes foi maior em relação aos machos decorrente da transfixação bicortical. Oito semanas após a instalação dos implantes a massa corporal dos animais não apresentaram diferenças significativas com os aferidos no dia da cirurgia e nem em relação ao sexo (Tabela 4).

Tabela 4. Dados de massa corporal $(\mathrm{Kg})$ dos animais no dia da cirurgia (Mi), após 8 semanas da cirurgia (Mf) e a diferença entre as massas final e inicial (Mf-Mi).

\begin{tabular}{lccc}
\hline \multirow{2}{*}{\multicolumn{1}{c}{ Animais }} & \multicolumn{3}{c}{ Massa corporal (Kg) } \\
\cline { 2 - 4 } Macho & $\begin{array}{c}\text { Dia da Cirurgia } \\
\text { (Mi) }\end{array}$ & $\begin{array}{c}\text { Dia da Coleta } \\
\text { 8 semanas (Mf) }\end{array}$ & Teste "t” pareado \\
Fêmea & $4,10 \pm 0,30^{*}$ & $3,92 \pm 0,40$ & $\mathrm{p}=0,055$ \\
Teste " $\mathrm{t}$ " & $4,26 \pm 0,34$ & $4,18 \pm 0,56$ & $\mathrm{p}=0,752$ \\
independente & $\mathrm{p}=0,694$ & $\mathrm{p}=0,202$ & \\
\hline
\end{tabular}

*Média e desvio padrão $(n=10)$ 


\subsection{MARCADORES DE DEPOSIÇÃO ÓSSEA FLUORESCENTE}

\subsubsection{Descrição morfológica do padrão de marcação ao microscópio confocal.}

O padrão de marcação foi similar entre os grupos, ou seja, aos 56 dias pós a colocação dos implantes verificou-se maior marcação/incorporação da Tetraciclina aplicada aos 14 e 21 dias, indicando maior deposição óssea neste período, seguido pela Alizartina aplicada aos 28 e 35 dias e em menor intensidade pela Calceína aplicada aos 42 e 49 dias.

Com relação aos grupos, no grupo GE-1 ocorreu menor intensidade de marcação para os 3 marcadores em relação aos demais grupo GE-2 e GC tanto em relação as fêmeas (Figuras 15, 16, 19 e 21) quanto aos machos (Figuras 17, 18, 20 e 22).

Com relação ao sexo, apenas no grupo GE-1 ocorreu maior intensidade de marcação da tetraciclina e da calceína (Figuras 15, 16, 17 e 18) nos machos em relação às fêmeas, reduzindo a intensidade da alizarina na imagem overlay dos machos. 


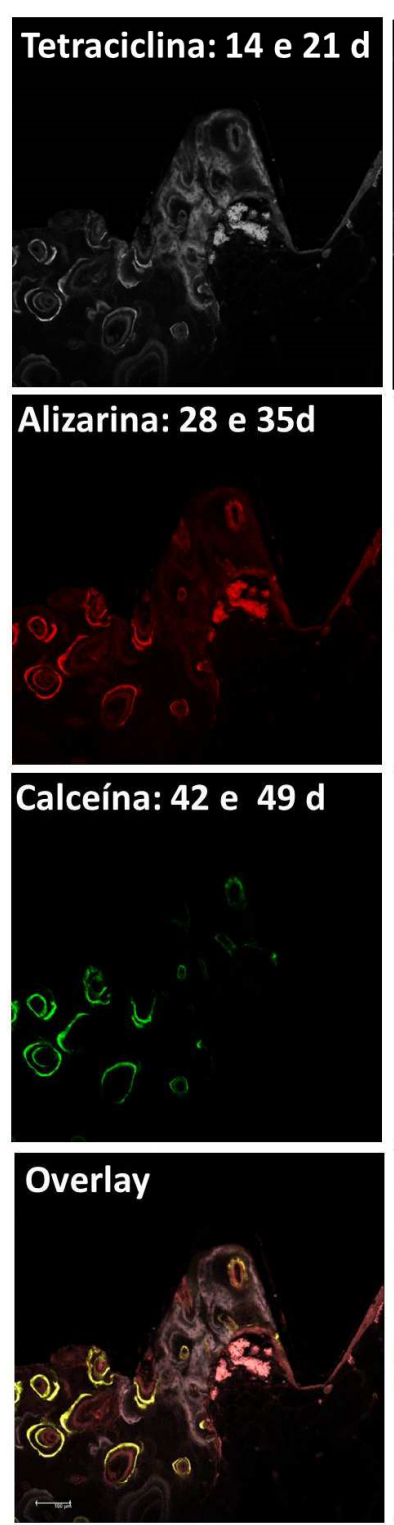

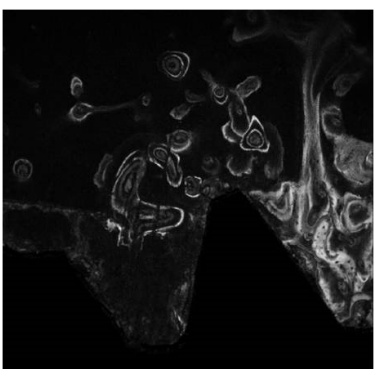
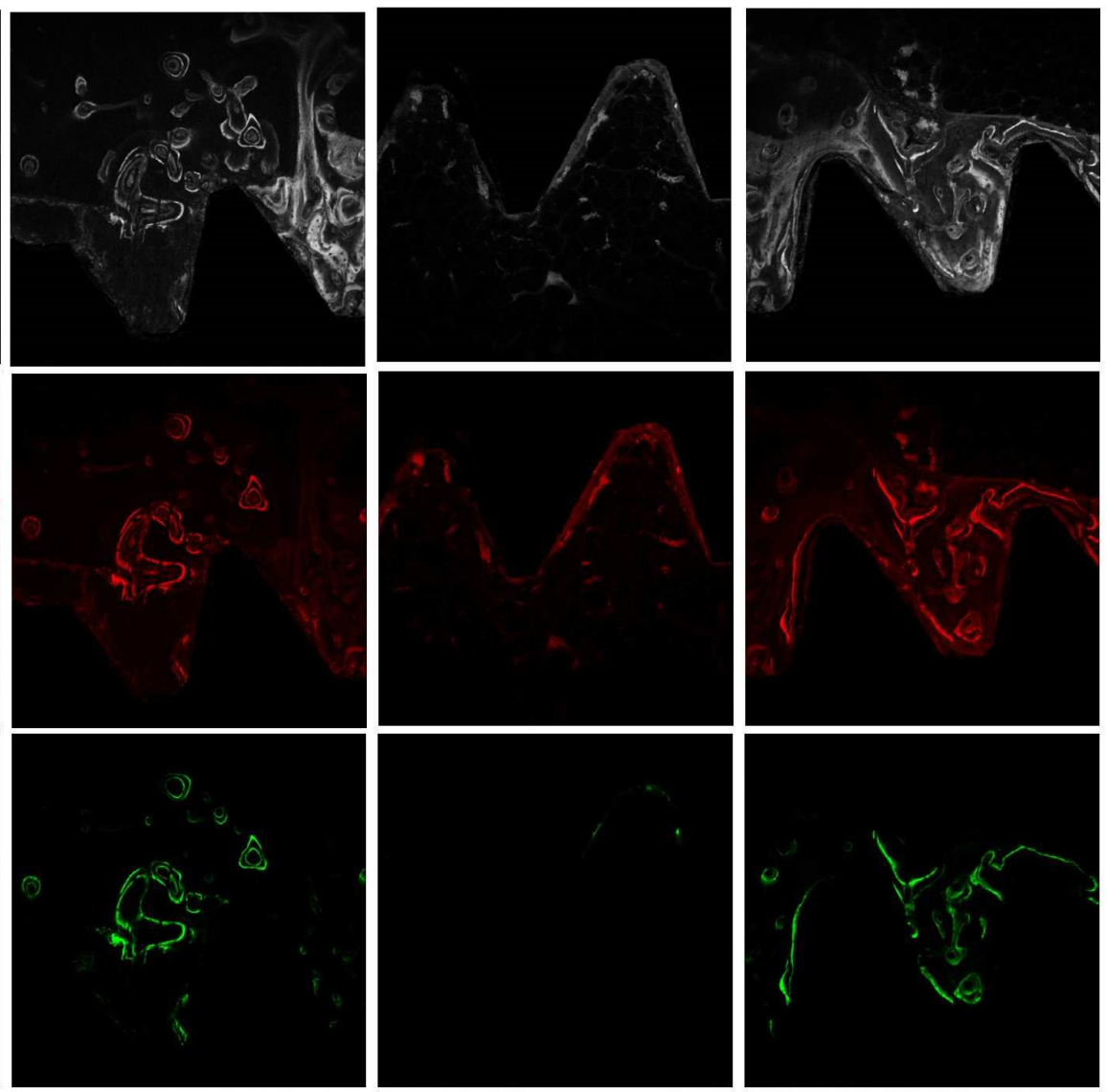

GE-1 (1A)

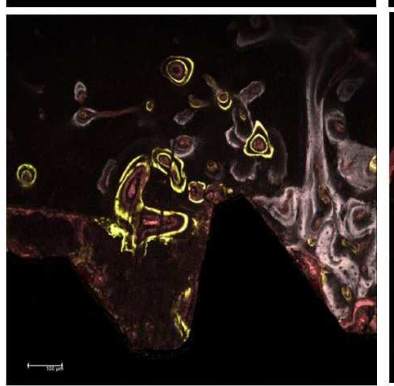

GE-1 (1B)

Tetraciclina $=20,82$

Alizarina $=14,29$

Calceína $=4,19$

Overlay $=23,11$
Tetraciclina $=26,03$

Alizarina $=10,03$

Calceína $=4,69$

Overlay $=28,87$

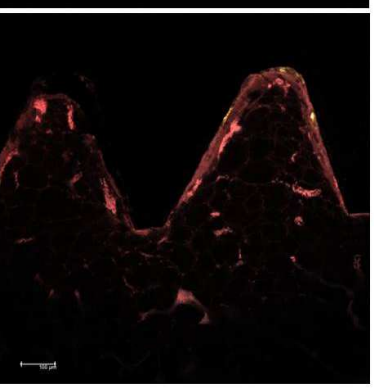

GE-1 (2A)

Tetraciclina $=6,18$

Alizarina $=6,91$

Calceína $=0,22$

Overlay $=6,33$
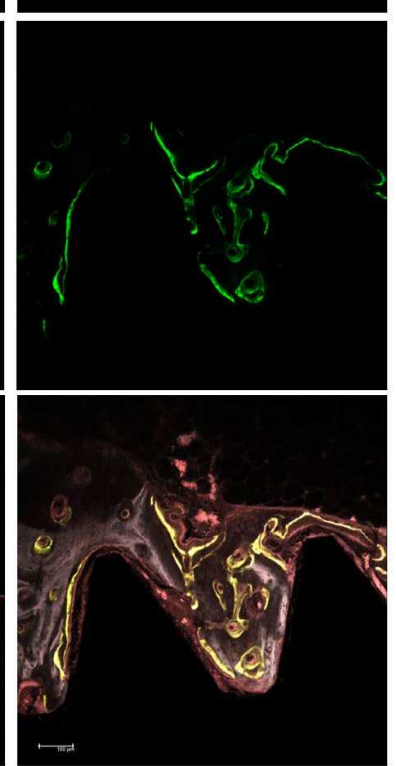

GE-1 (2B)

Tetraciclina $=38,18$

Alizarina $=19,41$

Calceína $=6,03$

Overlay $=39,21$

Figura 15 Fotomicrografias obtidas no microscópio confocal das superfícies do implante do grupo GE-1-cerâmica (Fêmea) da amostra C1 na região cortical (1A e 2A) e medular (1B e 2B) para Tetraciclina, Alizarina, Calceína e Overlay e os valores percentuais obtidos para cada marcador. 


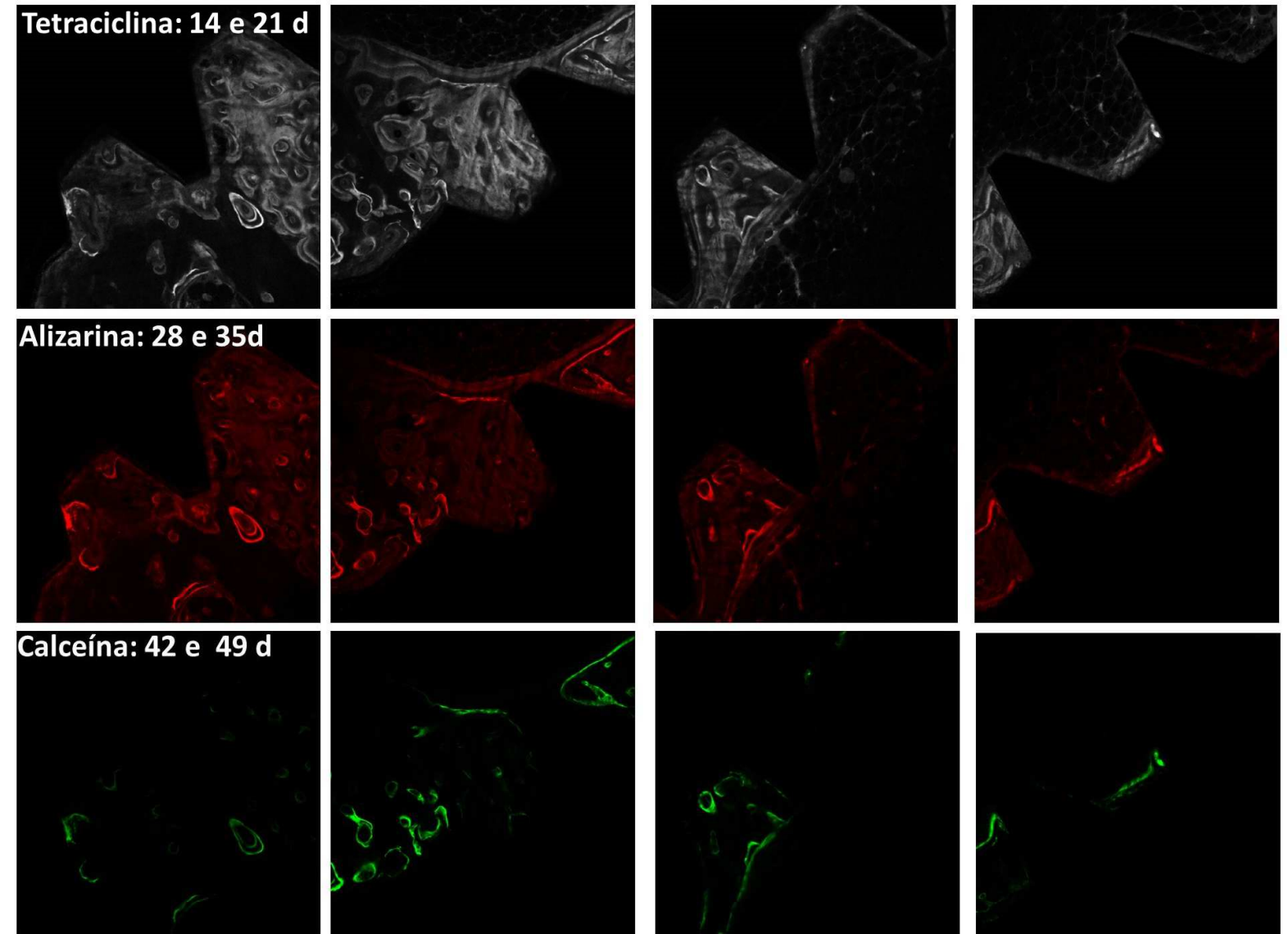

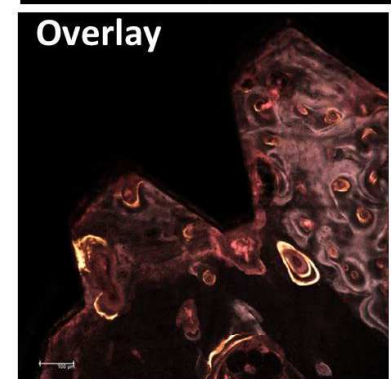

GE-1 (1A)

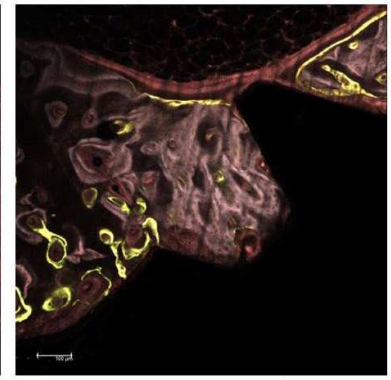

GE-1 (1B)

Tetraciclina $=20,82$

Alizarina $=14,29$

Calceína $=4,19$

Overlay $=23,11$

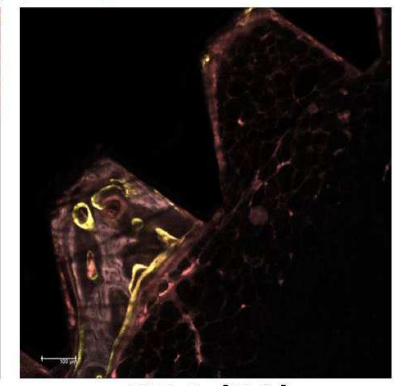

GE-1 (2A)

Tetraciclina $=6,18$

Alizarina $=6,91$

Calceína $=0,22$

Overlay $=6,33$

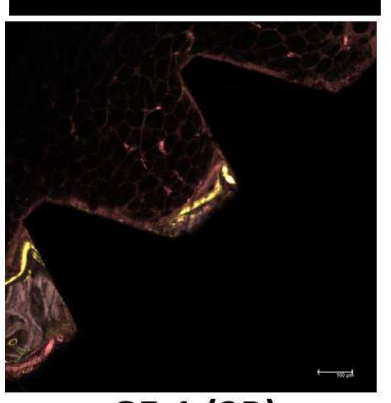

GE-1 (2B)

Tetraciclina $=\mathbf{3 8 , 1 8}$

Alizarina $=19,41$

Calceína $=6,03$

Overlay $=39,21$

Figura 16 Fotomicrografias obtidas no microscópio confocal das superfícies do implante do grupo GE1-cerâmica (Fêmea) da amostra C2 na região cortical (1A e 2A) e medular (1B e 2B) para Tetraciclina, Alizarina, Calceína e Overlay e os valores percentuais obtidos para cada marcador. 


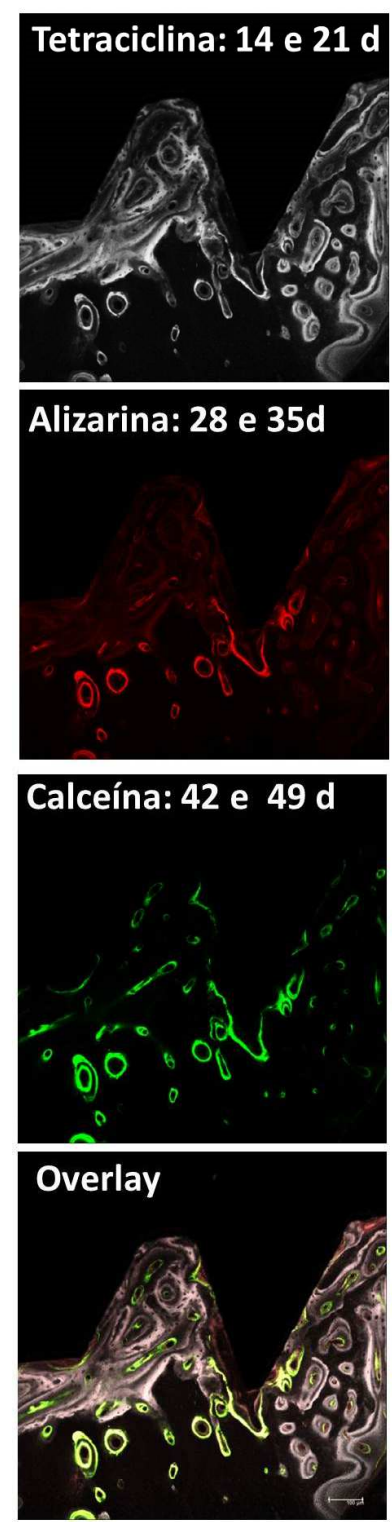

GE-1 (1A)
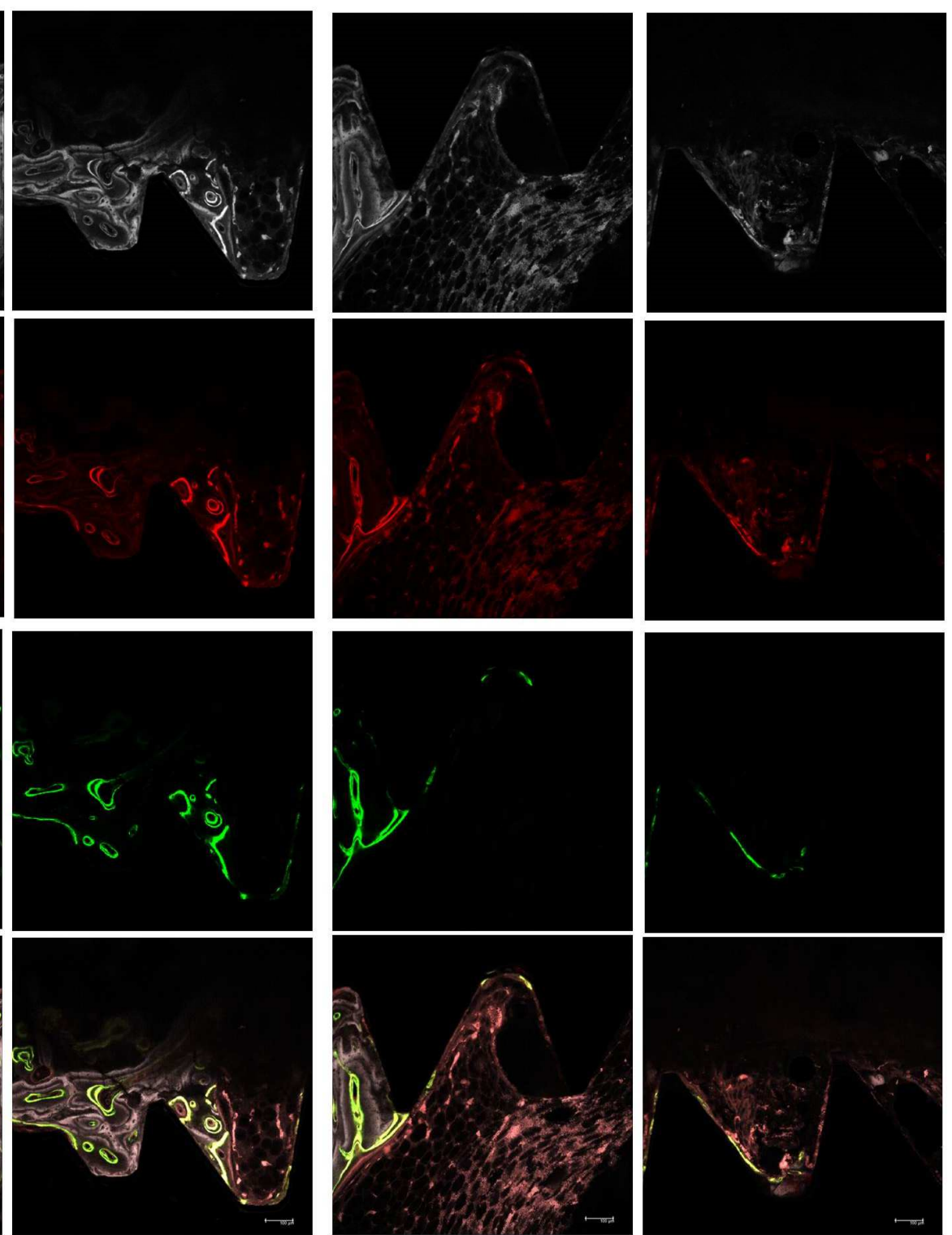

GE-1 (1B)

Tetraciclina $=50,53$ Tetraciclina $=21,46$

Alizarina $=14,13$

Calceína $=9,54$

Alizarina $=8,65$

Calceína $=4,98$

Overlay $=53,47$

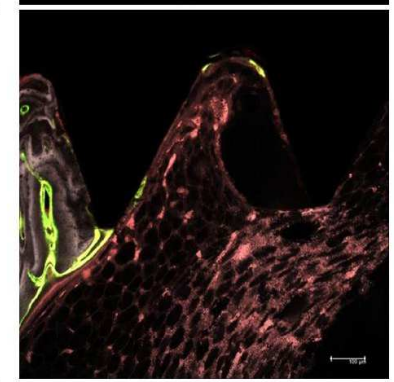

GE-1 (2A)

Tetraciclina $=14,17$

Alizarina $=18,17$

Calceína $=3,45$

Overlay $=34,33$

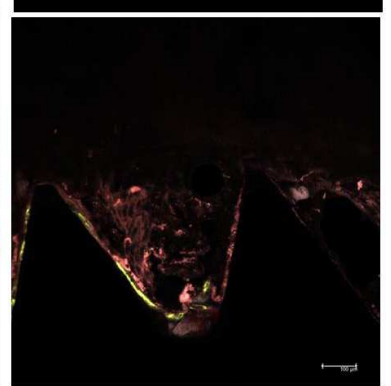

GE-1 (2B)

Tetraciclina $=4,26$

Alizarina $=4,70$

Calceína $=0,83$

Overlay $=6,66$

Figura 17 Fotomicrografias obtidas no microscópio confocal das superfícies do implante do grupo GE-1-cerâmica (Macho) da amostra C3 na região cortical (1A e 2A) e medular (1B e 2B) para Tetraciclina, Alizarina, Calceína e Overlay e os valores percentuais obtidos para cada marcador. 


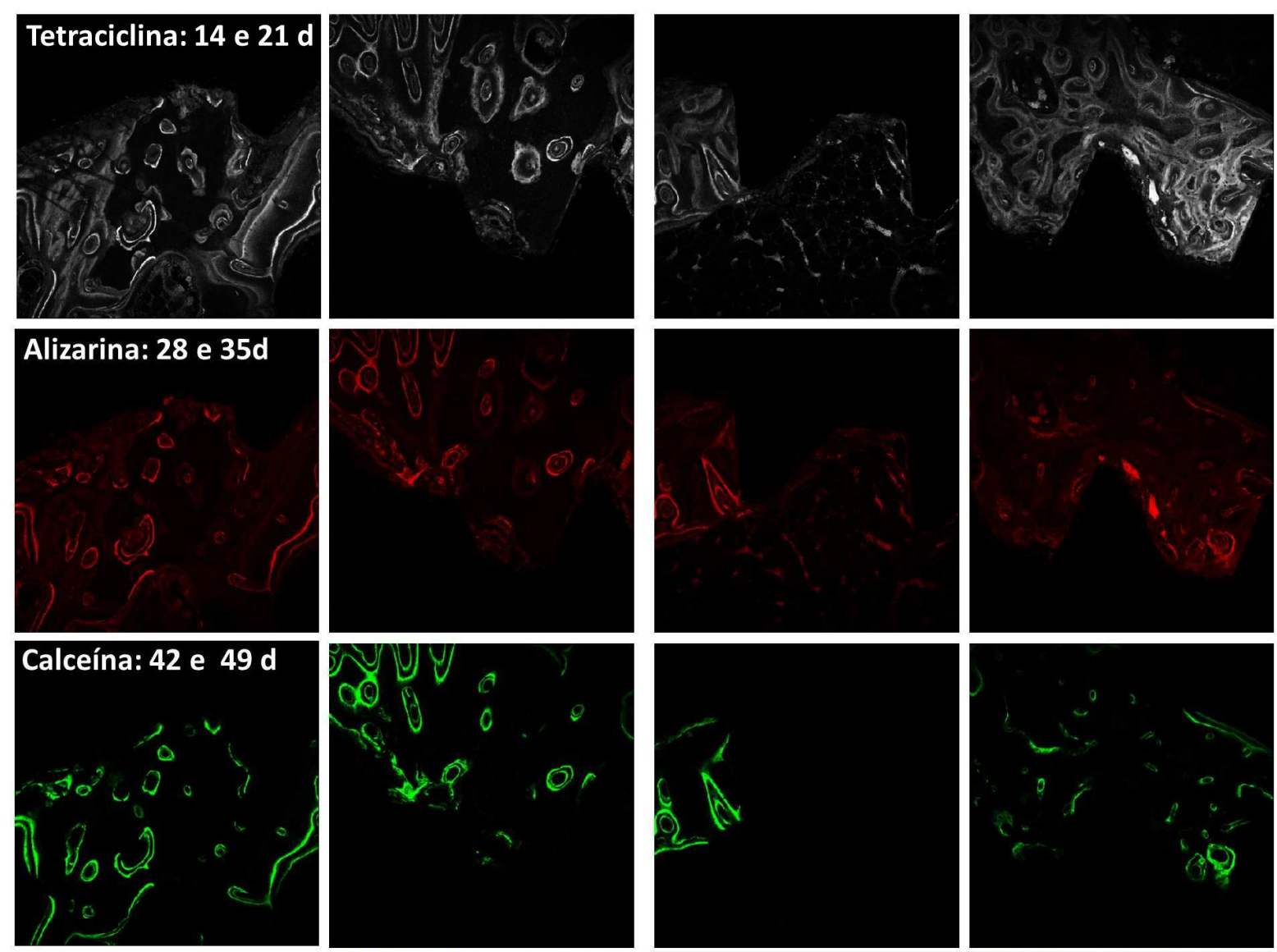

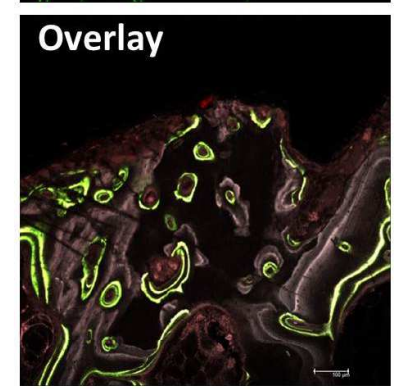

GE-1 (1A)

Tetraciclina $=25,85$

Alizarina $=11,11$

Calceína $=10,13$

Overlay $=\mathbf{3 8 , 7 7}$

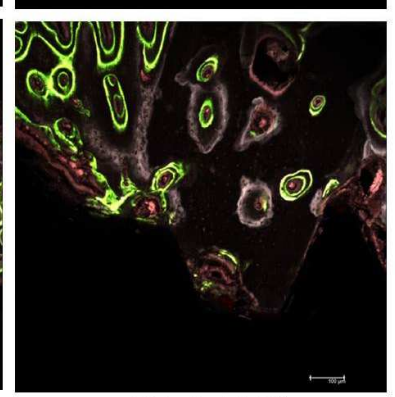

GE-1 (1B)

Tetraciclina $=17,79$

Alizarina $=11,68$

Calceína $=11,79$

Overlay $=30,40$

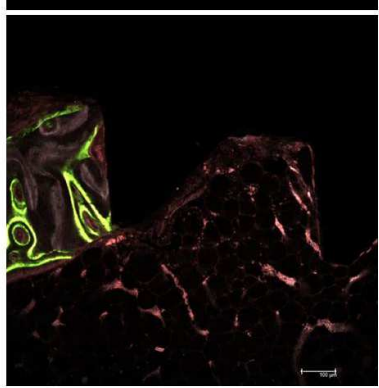

GE-1 (2A)

Tetraciclina $=\mathbf{8 , 9 0}$

Alizarina $=6,97$

Calceína $=4,76$

Overlay $=15,35$

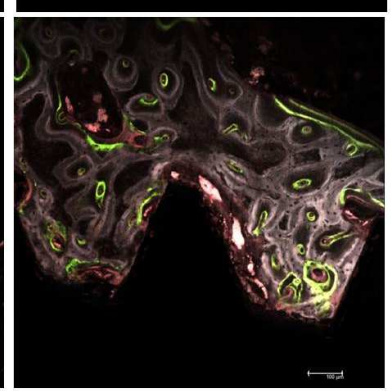

GE-1 (2B )

Tetraciclina $=\mathbf{3 8 , 1 0}$

Alizarina $=10,64$

Calceína $=6,26$

Overlay $=48,49$

Figura 18 Fotomicrografias obtidas no microscópio confocal das superfícies do implante do grupo GE-1-cerâmica (Macho) da amostra C6 na região cortical (1A e 2A) e medular (1B e 2B) para Tetraciclina, Alizarina, Calceína e Overlay e os valores percentuais obtidos para cada marcador. 


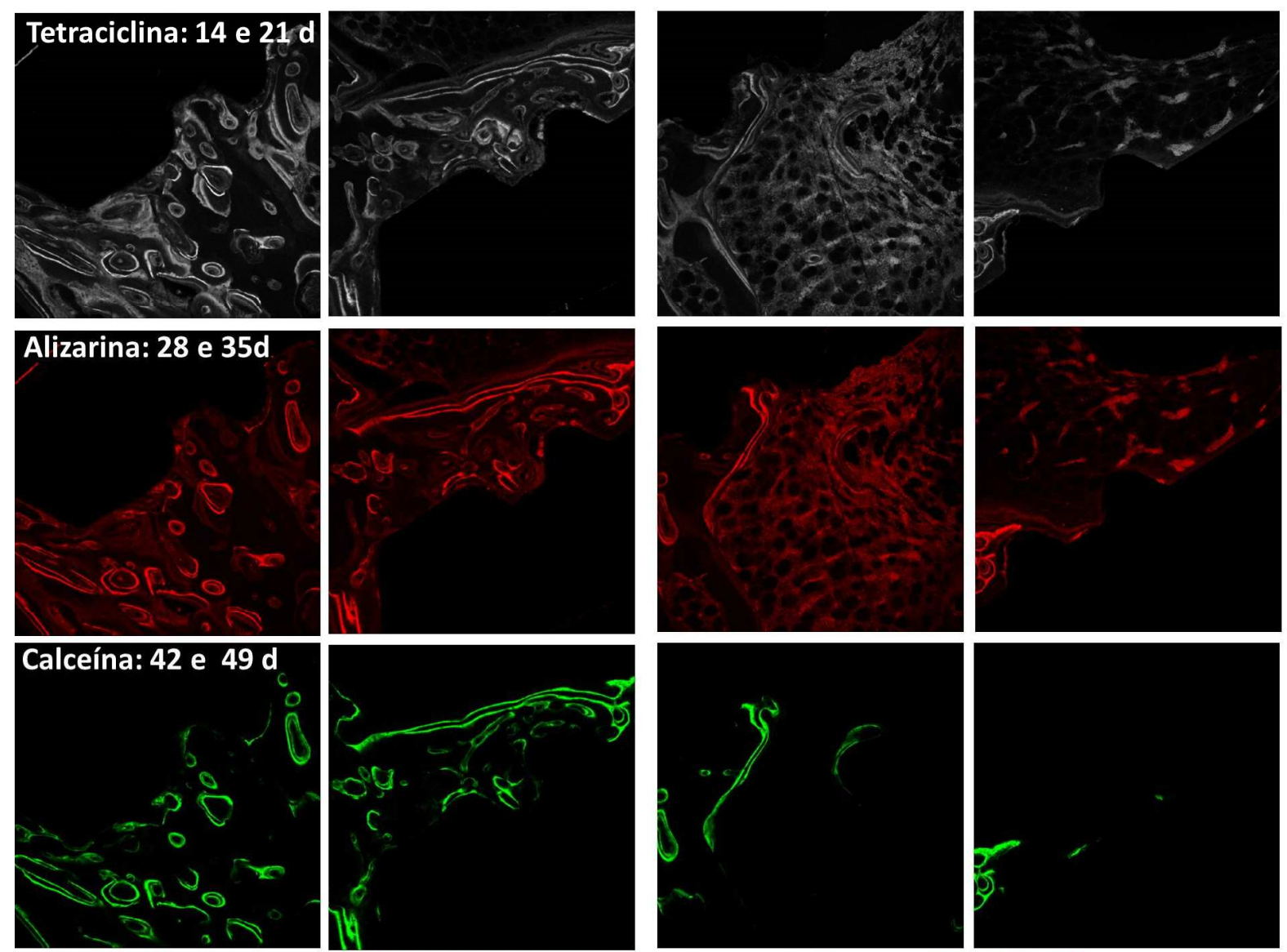

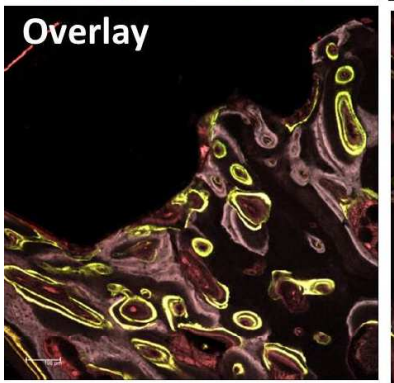

GE-2 (1A)

Tetraciclina $=38,02$

Alizarina $=35,84$

Calceína $=14,72$

Overlay $=50,92$

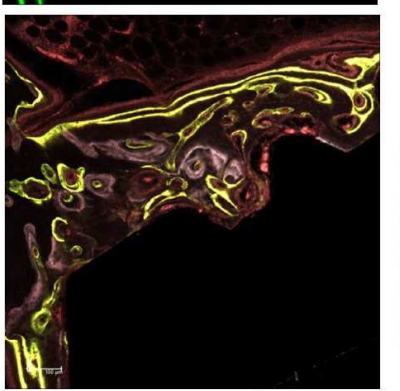

GE-2 (1B)

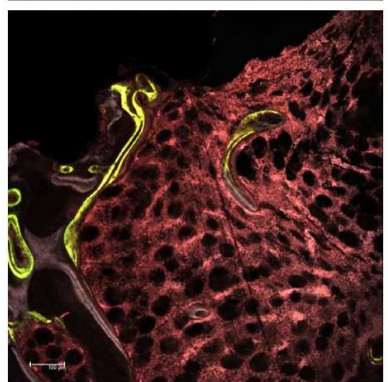

GE-2 (2A)

Tetraciclina $=37,48$

Alizarina $=46,53$

Calceína $=4,09$

Overlay $=49,81$

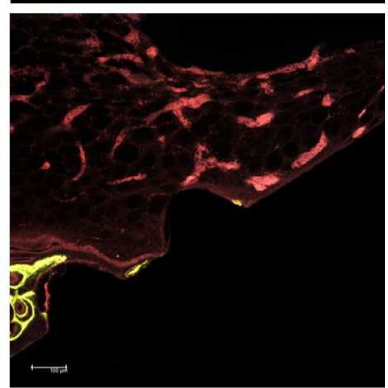

GE-2 (2B)

Tetraciclina $=8,91$

Alizarina $=16,34$

Calceína $=2,27$

Overlay $=13,30$

Figura 19 - Fotomicrografias obtidas no microscópio confocal das superfícies do implante do grupo GE-2-implante de superfície tratada (Fêmea) da amostra G1 na região cortical (1A e 2A) e medular $(1 B$ e $2 B)$ para Tetraciclina, Alizarina, Calceína e Overlay e os valores percentuais obtidos para cada marcador. 


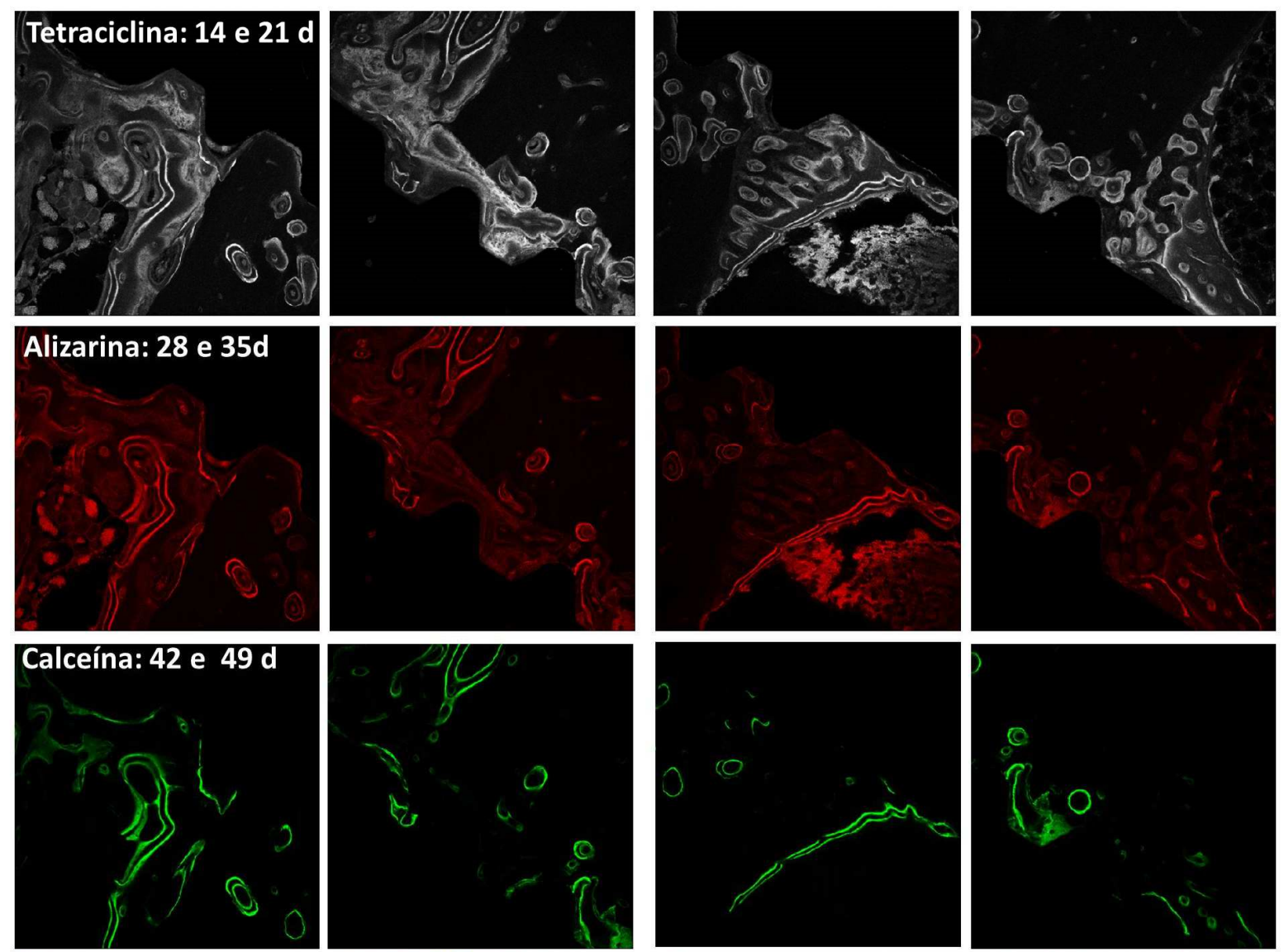

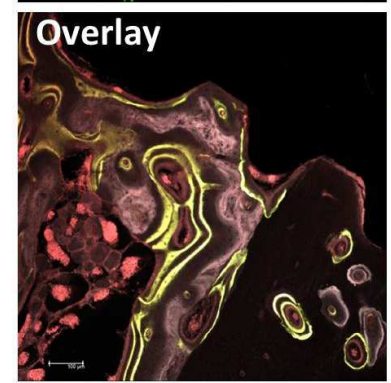

GE-2 (1A)

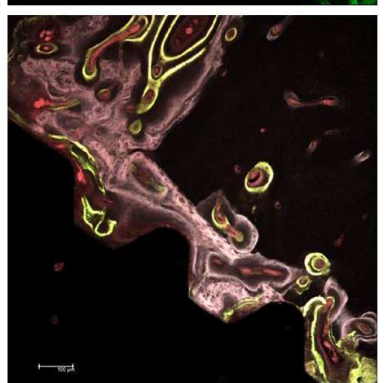

GE-2 (1B)

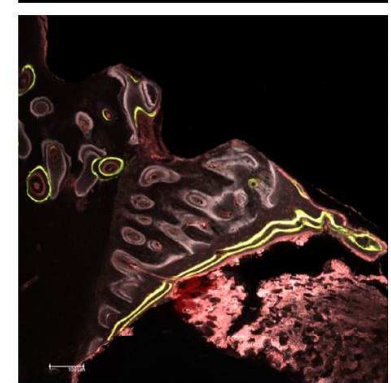

GE-2 (2A)

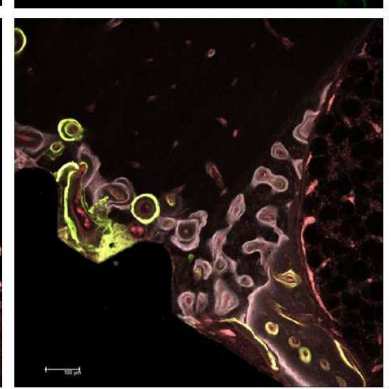

GE-2 (2B)

Tetraciclina $=42,82$ Tetraciclina $=37,32$ Tetraciclina $=34,74$ Tetraciclina $=22,11$

Alizarina $=37,68 \quad$ Alizarina $=29,20 \quad$ Alizarina $=24,93 \quad$ Alizarina $=14,86$

Calceína $=11,98 \quad$ Calceína $=8,73 \quad$ Calceína $=3,98 \quad$ Calceína $=5,39$

Overlay $=55,41 \quad$ Overlay $=45,44$

Overlay $=42,41$

Overlay $=29,52$

Figura 20 - Fotomicrografias obtidas no microscópio confocal das superfícies do implante do grupo GE-2-implante de superfície tratada (Macho) da amostra G5 na região cortical (1A e 2A) e medular $(1 B$ e $2 B$ ) para Tetraciclina, Alizarina, Calceína e Overlay e os valores percentuais obtidos para cada marcador. 


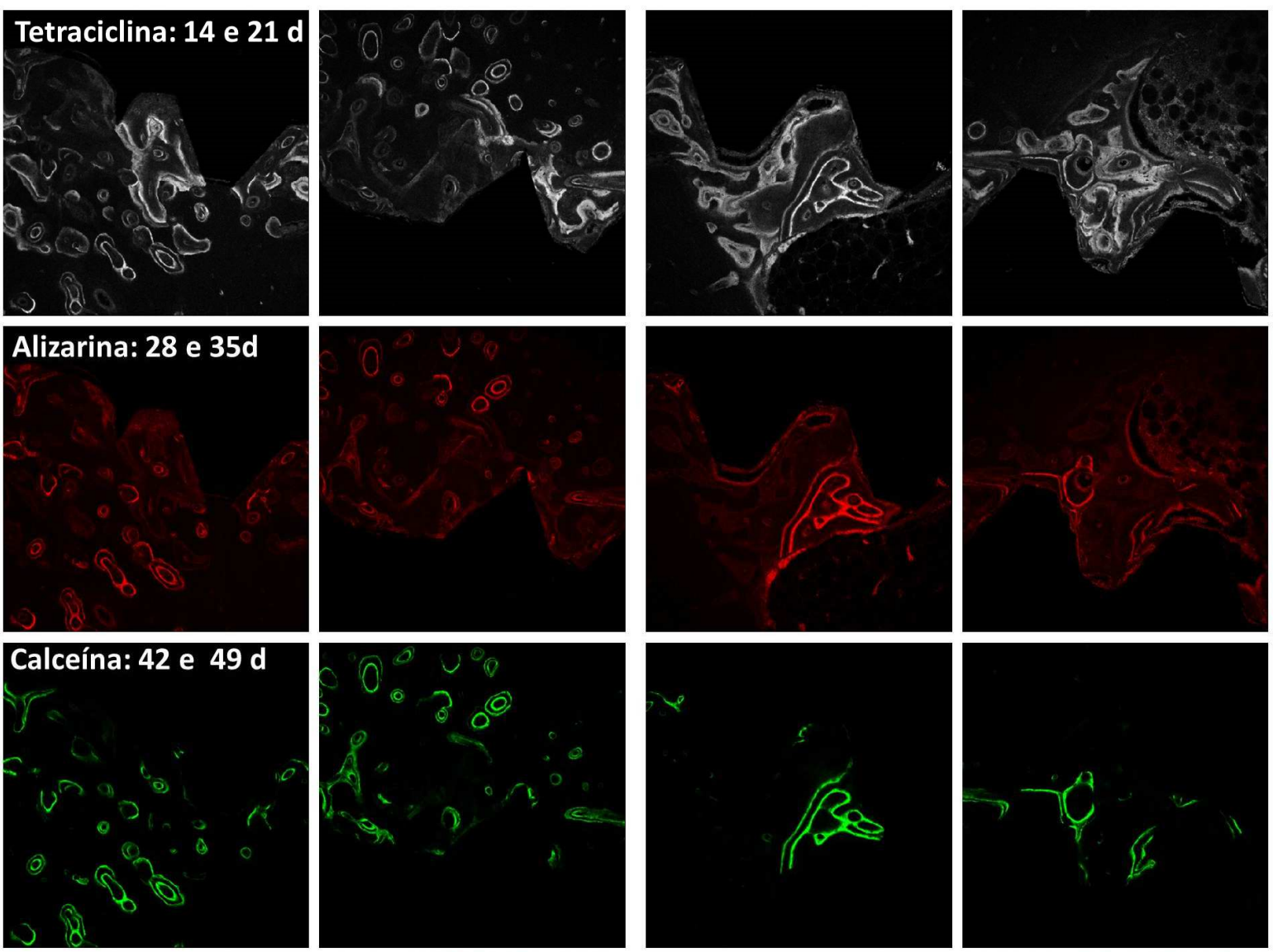

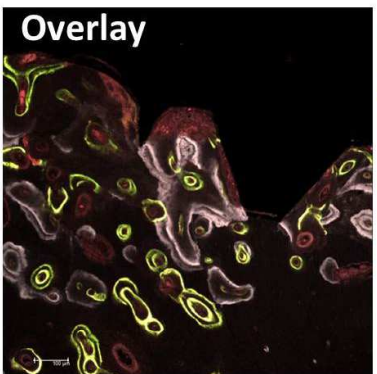

$$
\text { GC (1A) }
$$

Tetraciclina $=20,74$

Alizarina $=16,20$

Calceína $=8,74$

Overlay $=32,45$

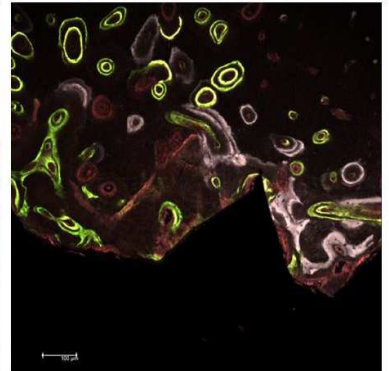

GC (1B)

Tetraciclina $=17,49$

Alizarina $=15,17$

Calceína $=10,37$

Overlay $=30,26$

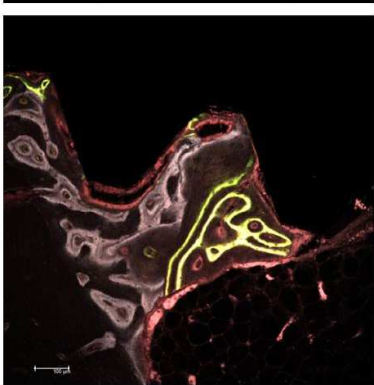

GC (2A)

Tetraciclina $=2,60$

Alizarina $=1,74$

Calceína $=0,49$

Overlay $=3,46$

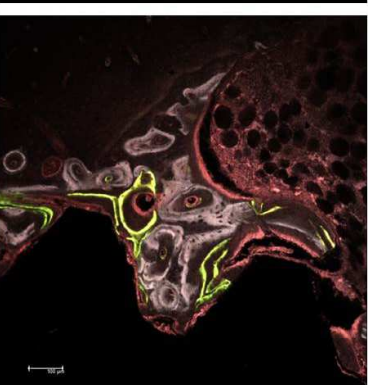

GC (2B)

Tetraciclina $=\mathbf{2 7 , 7 7}$

Alizarina $=17,97$

Calceína $=\mathbf{3 , 5 8}$

Overlay $=37,11$

Figura 21 - Fotomicrografias obtidas no microscópio confocal das superfícies do implante do grupo GC-implante usinado (Fêmea) da amostra T6 na região cortical (1A e 2A) e medular (1B e 2B) para Tetraciclina, Alizarina, Calceína e Overlay e os valores percentuais obtidos para cada marcador. 


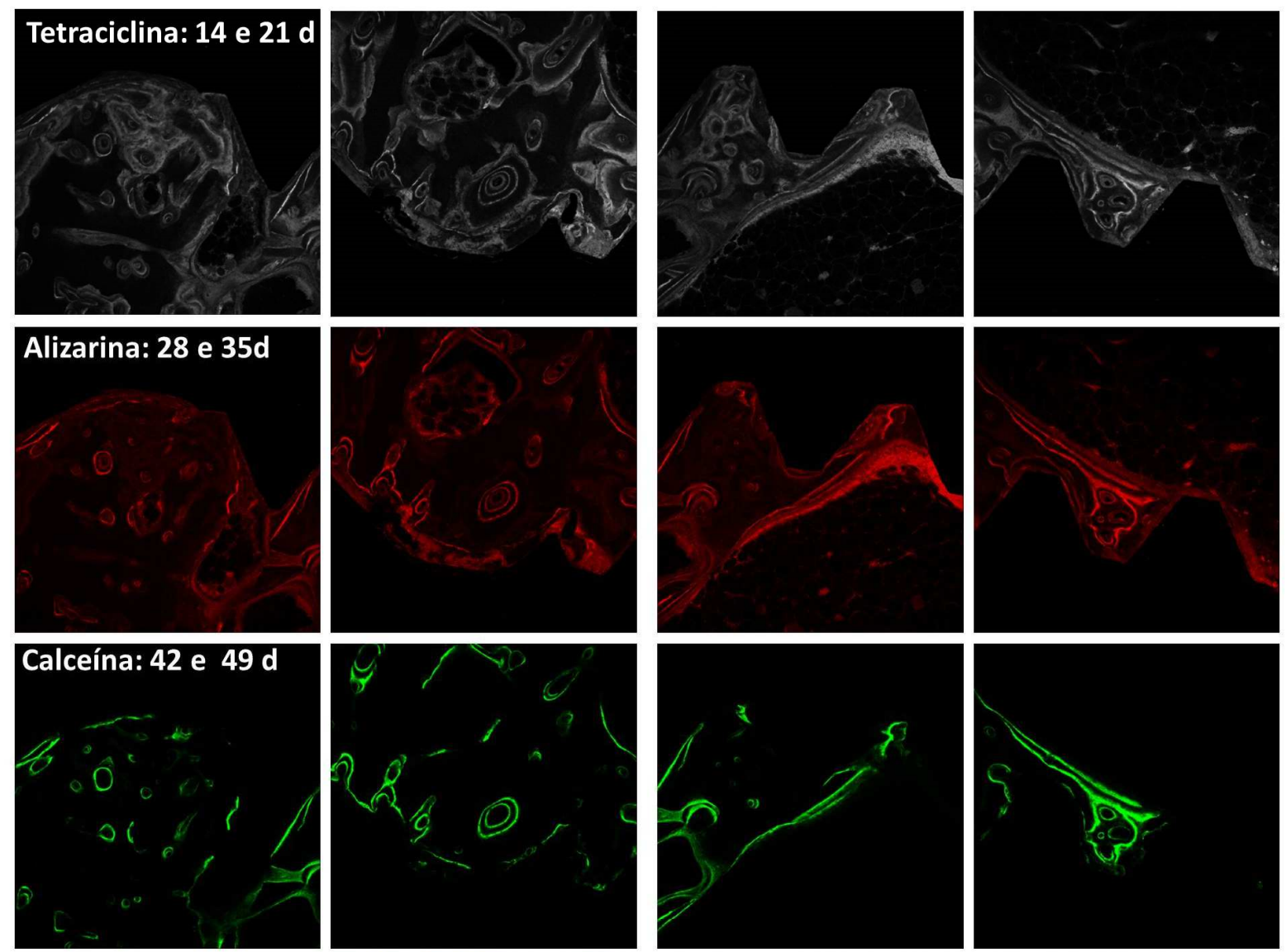

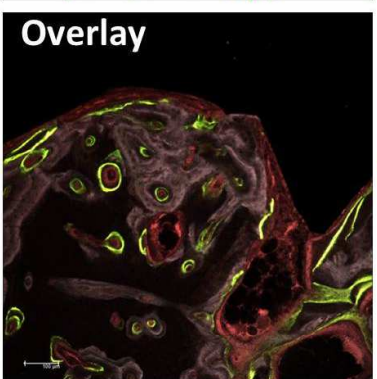

GC (1A)

Tetraciclina $=24,78$

Alizarina $=\mathbf{2 1 , 8 6}$

Calceína $=8,97$

Overlay $=40,48$

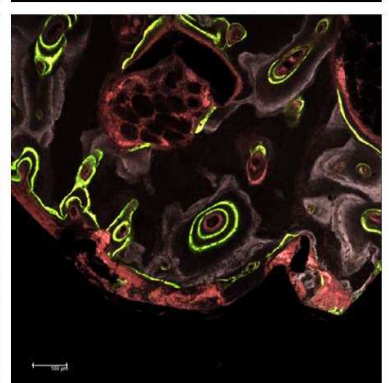

GC (1B)

Tetraciclina $=24,97$

Alizarina $=18,47$

Calceína $=8,16$

Overlay $=37,95$

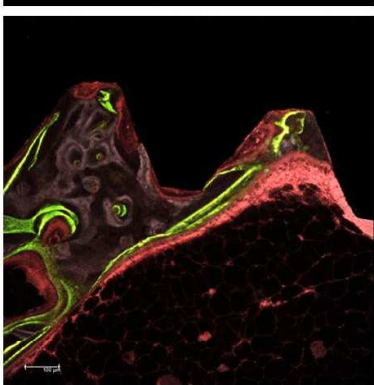

GC (2A)

Tetraciclina $=18,48$

Alizarina $=\mathbf{2 4 , 2 7}$

Calceína $=\mathbf{8 , 7 9}$

Overlay $=30,70$

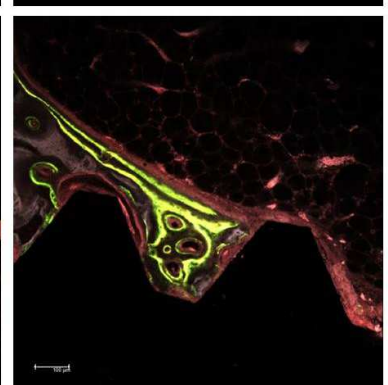

GC (2B)

Tetraciclina $=15,61$

Alizarina $=17,59$

Calceína $=7,70$

Overlay $=23,70$

Figura 22 - Fotomicrografias obtidas no microscópio confocal das superfícies do implante do grupo GC-implante usinado (Macho) da amostra T2 na região cortical (1A e 2A) e medular (1B e 2B) para Tetraciclina, Alizarina, Calceína e Overlay e os valores percentuais obtidos para cada marcador. 



\subsubsection{Quantificação do percentual de marcação - comparação entre os sexos}

Os dados obtidos para o percentual de marcação da tetraciclina, Alizarina, Calceína e o "Overlay" para Tetraciclina, Alizarina, Calceína e Overlay para machos e fêmeas estão apresentados nas Tabelas 5, 6, 7 e 8 e na Figura 23.

Tabela 5: Percentual de área (\%) para tetraciclina (aplicação aos 14 e 21 dias), nos diferentes grupos - Comparação entre sexos. Teste de Mann-Whitney.

\begin{tabular}{lccc}
\hline \multicolumn{1}{c}{ Grupos } & \multicolumn{2}{c}{ Percentual de área Tetraciclina (\%) } \\
& Fêmea & Macho & p \\
\hline GE1 - Cêramica & $21,94 \pm 8,64$ & $23,89 \pm 6,05$ & 0,573737 \\
\hline $\begin{array}{l}\text { GE2 - Titânio } \\
\text { tratado }\end{array}$ & $33,05 \pm 12,50$ & $35,67 \pm 2,01$ & 0,885714 \\
$\begin{array}{l}\text { GC - Titânio } \\
\text { usinado }\end{array}$ & $28,31 \pm 15,79$ & $27,18 \pm 7,41$ & 0,885714 \\
\hline
\end{tabular}

Tabela 6: Percentual de área (\%) para Alizarina (aplicação aos 28 e 35 dias), nos diferentes grupos Comparação entre sexos. Teste de Mann-Whitney.

\begin{tabular}{lccc}
\hline \multicolumn{1}{c}{ Grupos } & \multicolumn{2}{c}{ Percentual de área Alizarina (\%) } \\
& Fêmea & Macho & p \\
\hline GE-1 - Cêramica & $15,60 \pm 5,13$ & $14,78 \pm 6,54$ & 0,382284 \\
\hline $\begin{array}{l}\text { GE-2 - Titânio } \\
\text { tratado }\end{array}$ & $29,40 \pm 10,30$ & $32,65 \pm 8,47$ & 0,485714 \\
\hline $\begin{array}{l}\text { GC - Titânio } \\
\text { usinado }\end{array}$ & $16,10 \pm 4,70$ & $20,25 \pm 1,87$ & 0,685714 \\
\hline
\end{tabular}


Tabela 7: Percentual de área (\%) para Calceína (aplicação aos 42 e 49 dias), nos diferentes grupos Comparação entre sexos. Teste de Mann-Whitney

\begin{tabular}{lccc}
\hline \multicolumn{1}{c}{ Grupos } & \multicolumn{3}{c}{ Percentual de área Calceína (\%) } \\
& Fêmea & Macho & p \\
\hline GE-1 - Cêramica & $5,14 \pm 3,92$ & $6,07 \pm 2,34$ & 0,798446 \\
\hline $\begin{array}{l}\text { GE-2 - Titânio } \\
\text { tratado }\end{array}$ & $11,16 \pm 3,49$ & $10,90 \pm 4,77$ & 0,342857 \\
\hline $\begin{array}{l}\text { GC - Titânio } \\
\text { usinado }\end{array}$ & $7,33 \pm 2,16$ & $7,91 \pm 0,56$ & 0,685714 \\
\hline
\end{tabular}

Tabela 8: Percentual de área (\%) para "Overlay" nos diferentes grupos - Comparação entre sexos. Teste de Mann-Whitney

\section{Percentual de área "Overlay" (\%)}

\begin{tabular}{lccc}
\multicolumn{1}{c}{ Grupos } & Fêmea & Macho & p \\
\hline GE-1 - Cêramica & $27,57 \pm 8,95$ & $32,68 \pm 4,92$ & 0,082984 \\
\hline $\begin{array}{l}\text { GE-2 - Titânio } \\
\text { tratado } \\
\text { GC - Titânio usinado }\end{array}$ & $44,64 \pm 11,61$ & $47,78 \pm 6,49$ & 0,885714 \\
\hline
\end{tabular}



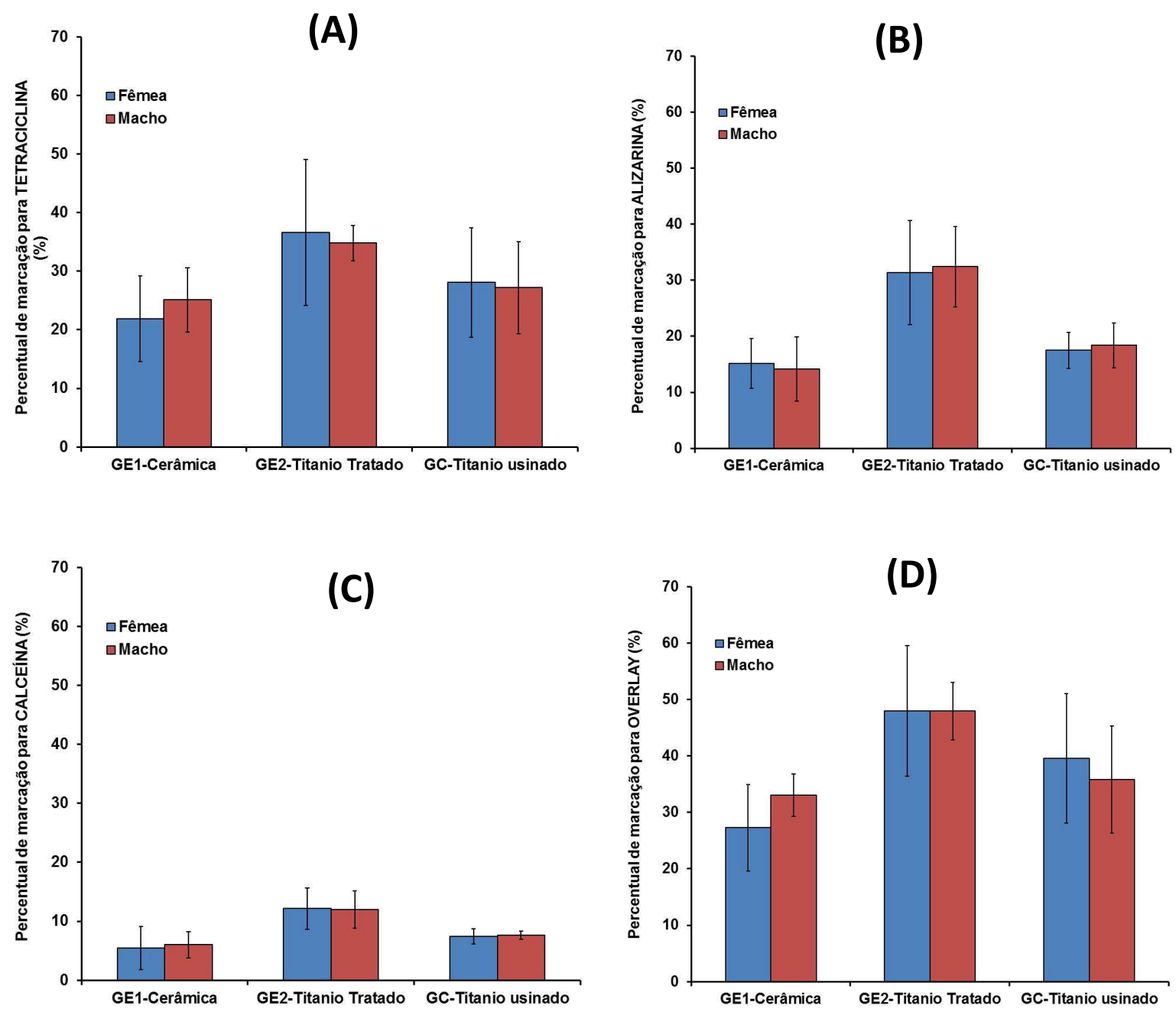

Figura 23 - Gráfico da média e do desvio padrão do percentual de área (\%) para Tetraciclina $(A)$, Alizarina (B), Calceína (C) e "Overlay" (D) obtido para machos e fêmeas de cada grupo. 
A análise das Tabelas 7 e 8 e da Figura 23 bem como da análise estatística dos dados mostram que entre os sexos não ocorreram diferenças quanto ao percentual de marcação para Tetraciclina, Alizarina, Calceína e Overlay.

\subsubsection{Quantificação do percentual de marcação - comparação entre os} grupos

Os dados obtidos para o percentual de marcação da Tetraciclina, Alizarina, Calceína e o "Overlay" para cada grupo na região Cortical, Medular e de ambas as regiões estão apresentados, respectivamente, nas Tabelas 9, 10 e 11 e na Figura 24. Como não ocorreram diferenças estatísticas entre machos e fêmeas para os diferentes marcadores os grupos GC, GE-1 e GE-2 foram compostos por machos e fêmeas indistintamentes.

Tabela 9: Percentual de área (\%) para tetraciclina (aplicação aos 14 e 21 dias), Alizarina (aplicação aos 28 e 35 dias), Calceína (aplicação aos 42 e 49 dias) e Overlay na região Cortical - Comparação entre grupos utilizando ANOVA a um critério e post-hoc teste de Tukey.

\begin{tabular}{|c|c|c|c|c|}
\hline \multirow[b]{2}{*}{ Marcadores } & \multicolumn{4}{|c|}{ Região Cortical (1A e 2A) } \\
\hline & $\begin{array}{c}\text { GE-1 } \\
\text { Cêramica }\end{array}$ & $\begin{array}{c}\text { GE-2 - Titânio } \\
\text { tratado }\end{array}$ & $\begin{array}{c}\text { GC - Titânio } \\
\text { usinado }\end{array}$ & “p” \\
\hline Tetraciclina & $28,92 \pm 9,88^{A}$ & $35,85 \pm 9,39^{A}$ & $27,67 \pm 7,59^{A}$ & 0,162344 \\
\hline Alizarina & $15,79 \pm 6,03^{B}$ & $37,76 \pm 10,83^{A}$ & $18,81 \pm 4,18^{\mathrm{B}}$ & 0,000000 \\
\hline Calceína & $7,32 \pm 3,47^{\mathrm{B}}$ & $16,71 \pm 4,96^{A}$ & $8,78 \pm 1,91^{\mathrm{B}}$ & 0,000006 \\
\hline “Overlay" & $36,25 \pm 8,65^{\mathrm{B}}$ & $50,54 \pm 9,31^{A}$ & $40,79 \pm 8,57^{A}$ & 0,003216 \\
\hline
\end{tabular}

Letras diferentes indicam diferença significante $(p<0,05)$. 
Tabela 10: Percentual de área (\%) para tetraciclina (aplicação aos 14 e 21 dias), Alizarina (aplicação aos 28 e 35 dias), Calceína (aplicação aos 42 e 49 dias) e Overlay na região medular - Comparação entre grupos utilizando ANOVA a um critério e post-hoc teste de Tukey.

\begin{tabular}{|c|c|c|c|c|}
\hline \multirow{2}{*}{ Marcadores } & \multicolumn{4}{|c|}{ Região Medular (1B e 2B) } \\
\hline & $\begin{array}{c}\text { GE1 - } \\
\text { Cêramica }\end{array}$ & $\begin{array}{l}\text { GE2 - Titânio } \\
\text { tratado }\end{array}$ & $\begin{array}{l}\text { GC - Titânio } \\
\text { usinado }\end{array}$ & “p” \\
\hline Tetraciclina & $18,08 \pm 6,71^{B}$ & $35,60 \pm 8,94^{A}$ & $25,06 \pm 14,87^{A}$ & 0,001191 \\
\hline Alizarina & $13,50 \pm 6,20^{\mathrm{B}}$ & $26,05 \pm 8,16^{A}$ & $17,07 \pm 7,03^{B}$ & 0,001028 \\
\hline Calceína & $4,17 \pm 2,84^{\mathrm{B}}$ & $7,47 \pm 2,41^{A}$ & $6,29 \pm 3,46^{A}$ & 0,033943 \\
\hline "Overlay" & $24,12 \pm 7,61^{B}$ & $45,39 \pm 8,92^{A}$ & $34,60 \pm 19,34^{A}$ & 0,000965 \\
\hline
\end{tabular}

Letras diferentes indicam diferença significante $(p<0,05)$.

Tabela 11: Percentual de área (\%) para tetraciclina (aplicação aos 14 e 21 dias), Alizarina (aplicação aos 28 e 35 dias), Calceína (aplicação aos 42 e 49 dias) e Overlay do total de marcação para a região cortical e medular - Comparação entre grupos utilizando ANOVA a um critério e post-hoc teste de Tukey.

\section{Região Cortical e Medular (1A, 2A, 1B e 2B)}

\begin{tabular}{lcccc}
\multicolumn{1}{c}{ Marcadores } & $\begin{array}{c}\text { GE1 - } \\
\text { Cêramica }\end{array}$ & $\begin{array}{c}\text { GE2 - Titânio } \\
\text { tratado }\end{array}$ & $\begin{array}{c}\text { GC - Titânio } \\
\text { usinado }\end{array}$ & " $p$ ” \\
\hline Tetraciclina & $23,50 \pm 6,48^{\mathrm{B}}$ & $35,72 \pm 8,46^{\mathrm{A}}$ & $26,37 \pm 8,21^{\mathrm{B}}$ & 0,002725 \\
\hline Alizarina & $14,64 \pm 4,99^{\mathrm{B}}$ & $31,91 \pm 7,72^{\mathrm{A}}$ & $17,94 \pm 3,41^{\mathrm{B}}$ & 0,000000 \\
\hline Calceína & $5,74 \pm 2,93^{\mathrm{B}}$ & $12,09 \pm 3,09^{\mathrm{A}}$ & $7,54 \pm 0,96^{\mathrm{B}}$ & 0,000027 \\
\hline “Overlay" & $30,18 \pm 6,56^{\mathrm{B}}$ & $47,97 \pm 8,30^{\mathrm{A}}$ & $37,70 \pm 9,93^{\mathrm{B}}$ & 0,000069 \\
\hline
\end{tabular}

Letras diferentes indicam diferença significante $(p<0,05)$. 

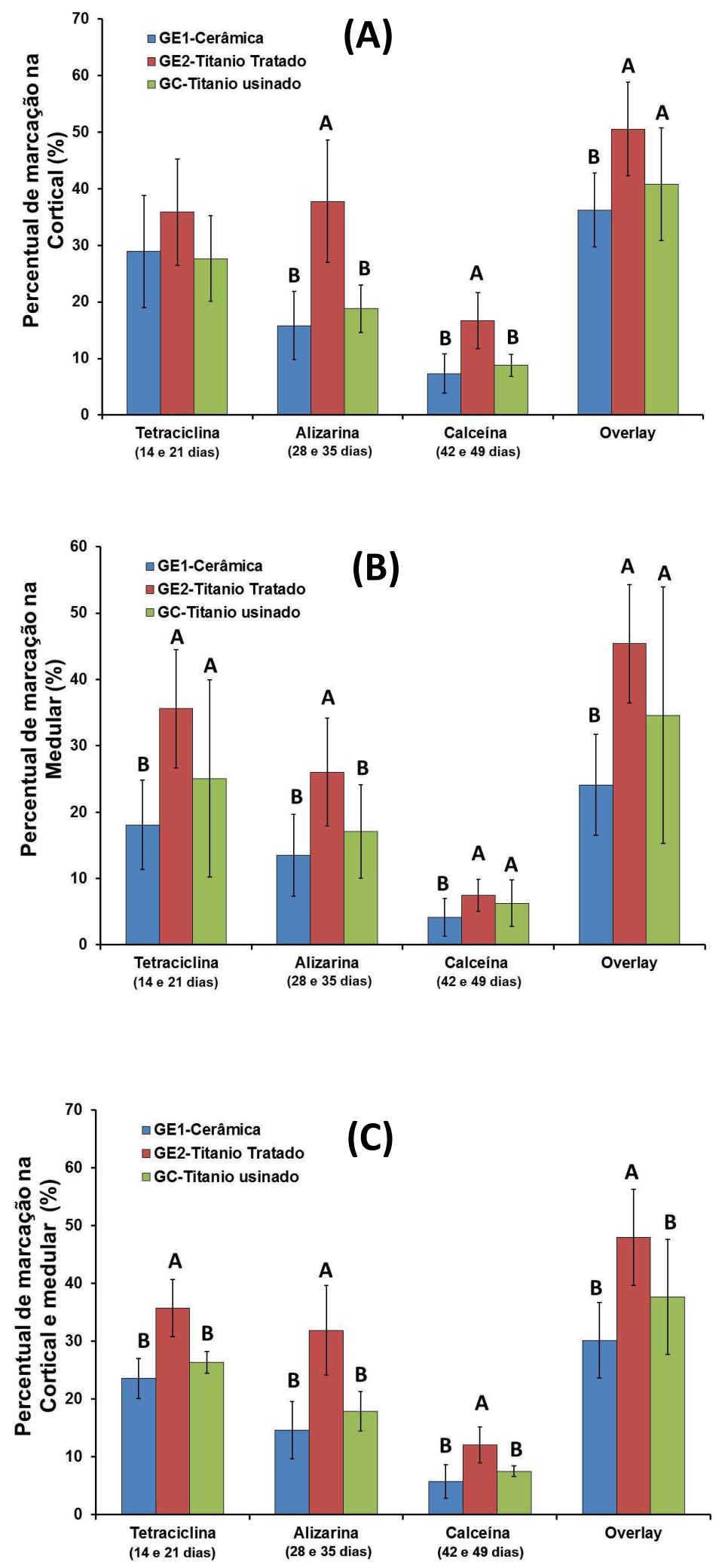

Figura 24 - Gráfico da média e do desvio padrão do percentual de área (\%) obtido para cada marcador e o overlay da região Cortical $(A)$, região medular $(B)$ e a média de ambas as regiões $(C)$ de cada grupo. Letras diferentes $p<0,05$ entre grupos por período. 
A análise das Tabelas 9 e-10 e da figura 24 mostram que:

a) na Cortical o percentual de marcação para tetraciclina não apresentou diferenças entre grupos, já a de alizarina e calceína no grupo GE-2 foi, respectivamente, 1,18 e 1,07 vezes maior em relação aos demais grupos. Já o percentual de marcação no overlay no grupo GE-2 e GC foi 0,36 vezes maior em relação ao GE-1.

b) na Medular o percentual de marcação nos grupos GE-2 e GC para tetraciclina, calceína e overlay foi respectivamente 0,67 vezes, 0,65 vezes e 0,65 vezes maior em relação ao GE-1, enquanto que, para alizarina somente o grupo GE-2 foi 0,70 vezes maior em relação aos demais grupos.

c) em ambas as regiões, Cortical + Medular o percentual de marcação para tetraciclina, alizarina, calceína e overlay no grupo GE-2 foi em média, respectivamente, 0,43 vezes, 0,95 vezes, 0,82 vezes e 0,41 vezes maior em relação aos demais grupos GE-1 e GC.

\subsection{FORMAÇÃO ÓSSEA NA SUPERFÍCIE DOS IMPLANTES AVALIADOS NOS CORTES DE TECIDO DURO CORADOS PELO AZUL DE TOLIDINA}

\subsubsection{Descrição morfológica dos cortes teciduais corados pelo Azul de Toluidina}

A análise descritiva dos cortes teciduais da região dos implantes corados pelo azul de toluidina mostrou que, após as 8 semanas de implantação a região cervical de todos os implantes dos grupos GC (Figuras 25, 26 e 27), GE-2 (Figuras 28, 29 e 30) e GE-1 (Figuras 31, 32, 33 e 34) estavam circundados por tecido ósseo compacto, sendo que, mais de $50 \%$ de sua superfície apresentava em contato direto com o tecido ósseo e o restante havia interposição por fina camada de tecido conjuntivo. A cortical óssea remanescente próxima ao implante dos GC (Figuras 25, 26 e 27) e GE-1 (Figuras 31, 32, 33 e 34) praticamente não apresentou sinais de reabsorção e o tecido ósseo formado ficou restrito a uma pequena faixa existente 
entre a cortical e o implante com característica de osso lamelar (Figura 27). No grupo GE-2 já era possível observar algumas áreas de remodelação óssea principalmente na região medular próxima a cortical (Figura 34). Vale salientar que a cerâmica por apresentar um grau de dureza elevado mesmo em relação ao meio de inclusão dificultou a obtenção de cortes com espessura uniformes, gerando um "degrau" entre o implante e o tecido adjacente (Figuras 33 e 34). Em contrapartida, no GE-2 (Figuras 28, 29 e 30) a cortical óssea remanescente próxima ao implante sofreu intensa reabsorção, gerando um extenso espaço entre a superfície do implante que foi preenchido por novo tecido ósseo mais imaturo em relação aos do GC. 

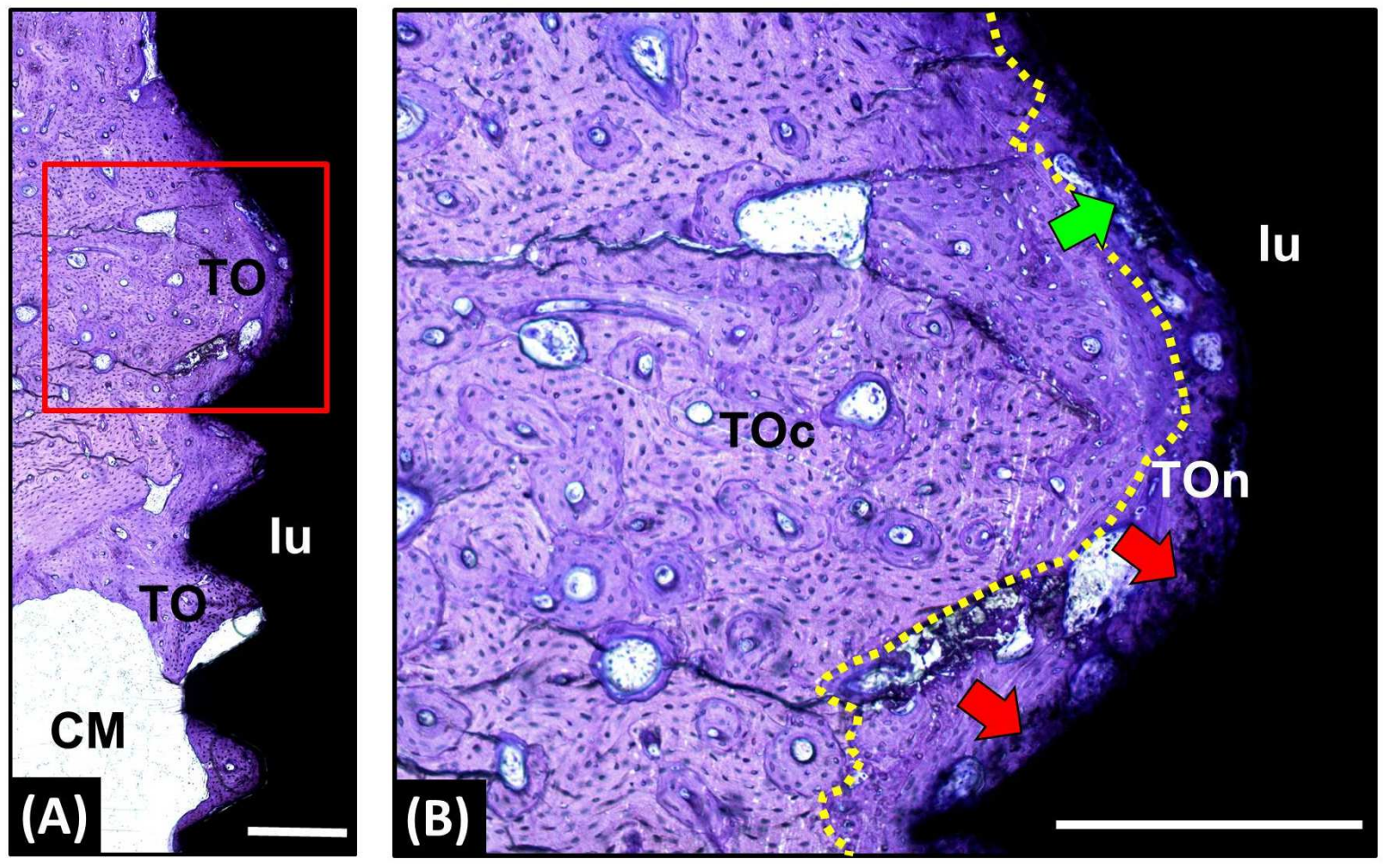

Figura 25: Fotomicrografia do GC após 8 semanas de instalação do implante de titânio usinado (lu): A) Imagem panorâmica da região cervical do implante (lu) mostrando o tecido ósseo (TO) recobrindo a superfície do implante (lu) e B) Detalhe da figura anterior na região cortical, mostrando a cortical íntegra (TOc, área tracejada) composta por tecido ósseo lamelar e a superfície do implante (lu) recoberta por tecido ósseo neoformado (TOn). Notar as várias áreas de contato osso-implante (seta vermelha) e alguns pontos com interposição de tecido conjuntivo (seta verde). $\mathrm{CM}=\mathrm{Canal}$ medular. Barra $=500 \mu \mathrm{m}$. Azul de Toluidina. 


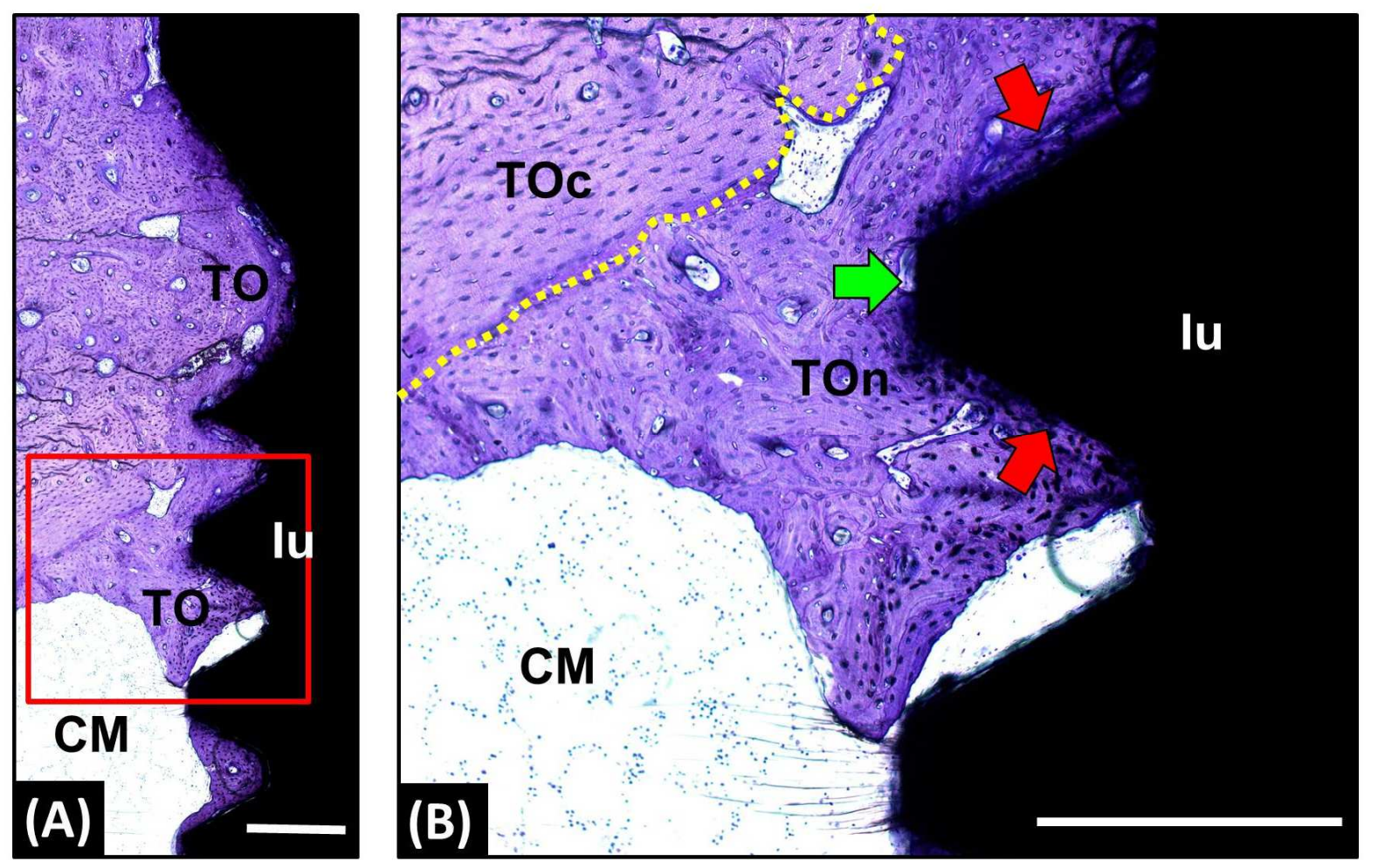

Figura 26: Fotomicrografia do GC após 8 semanas de instalação do implante de titânio usinado (lu): A) Imagem panorâmica da Região cervical do implante (lu) mostrando o tecido ósseo (TO) recobrindo a superfície do implante e B) Detalhe da figura anterior mostrando a região medular próxima à cortical mostrando o recobrimento parcial da superfície do implante (lu) por tecido ósseo neoformado (TOn). Como o observado na região cortical extensa áreas de contato osso-implante (seta vermelha) e apenas um pontos com interposição de tecido conjuntivo (seta verde). $\mathrm{CM}=$ Canal medular, TOc, área tracejada amarela $=$ cortical óssea. Barra $=500 \mu \mathrm{m}$. Azul de Toluidina. 


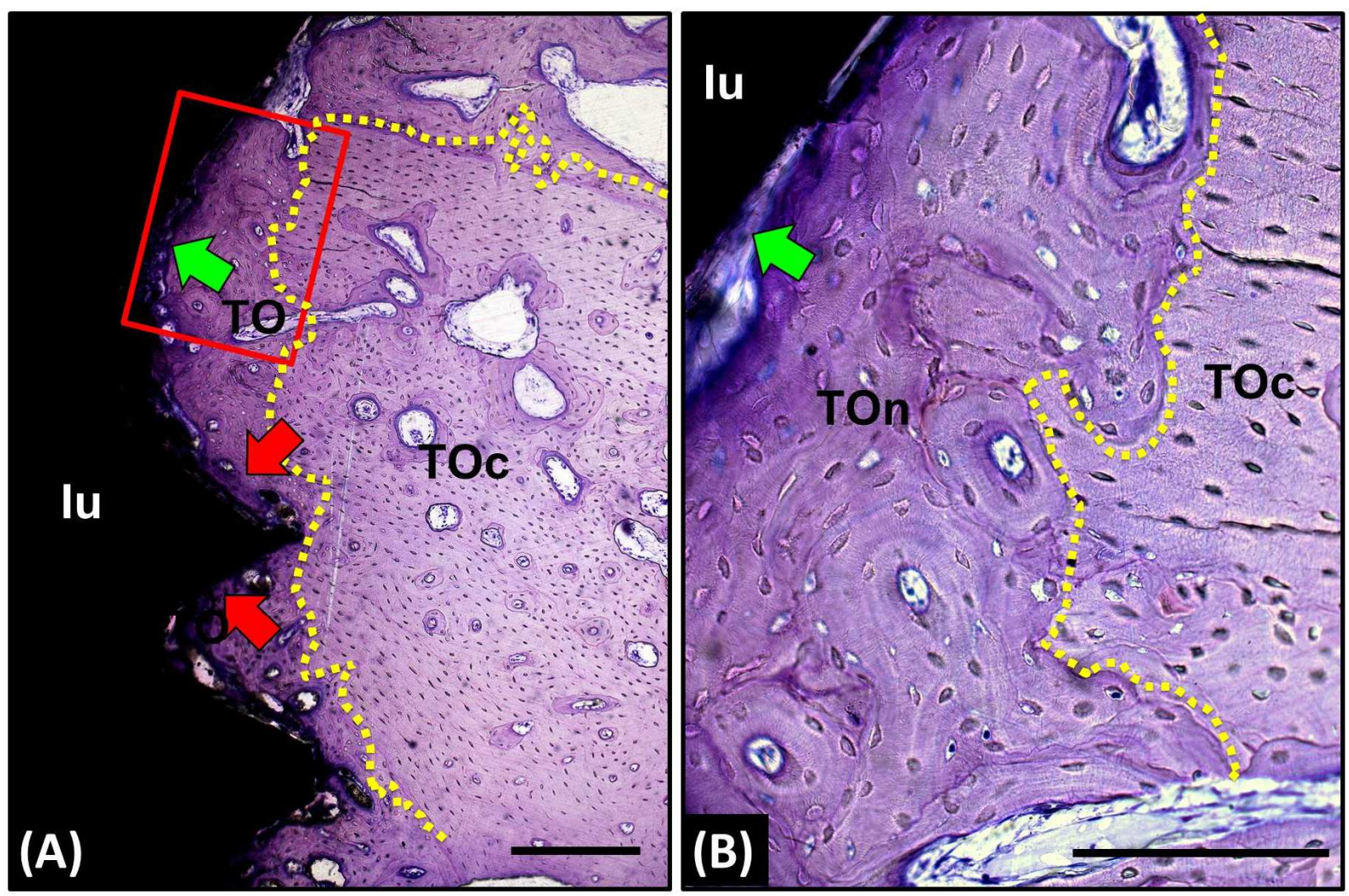

Figura 27: Fotomicrografia do GC após 8 semanas de instalação do implante de titânio usinado (lu): A) Imagem panorâmica da região Cortical mostrando a integridade do tecido ósseo compacto (TOc, área tracejada amarela) e os pontos de contato osso implante (seta vermelha) e as áreas de interposição por tecido conjuntivo (seta verde); B) Detalhe da figura anterior mostrando a formação óssea (TOn) entre a superfície do implante (lu) e a cortical óssea (TOc) e a interposição de tecido conjuntivo (seta verde). Barra $=250 \mu \mathrm{m}$. Azul de Toluidina. 


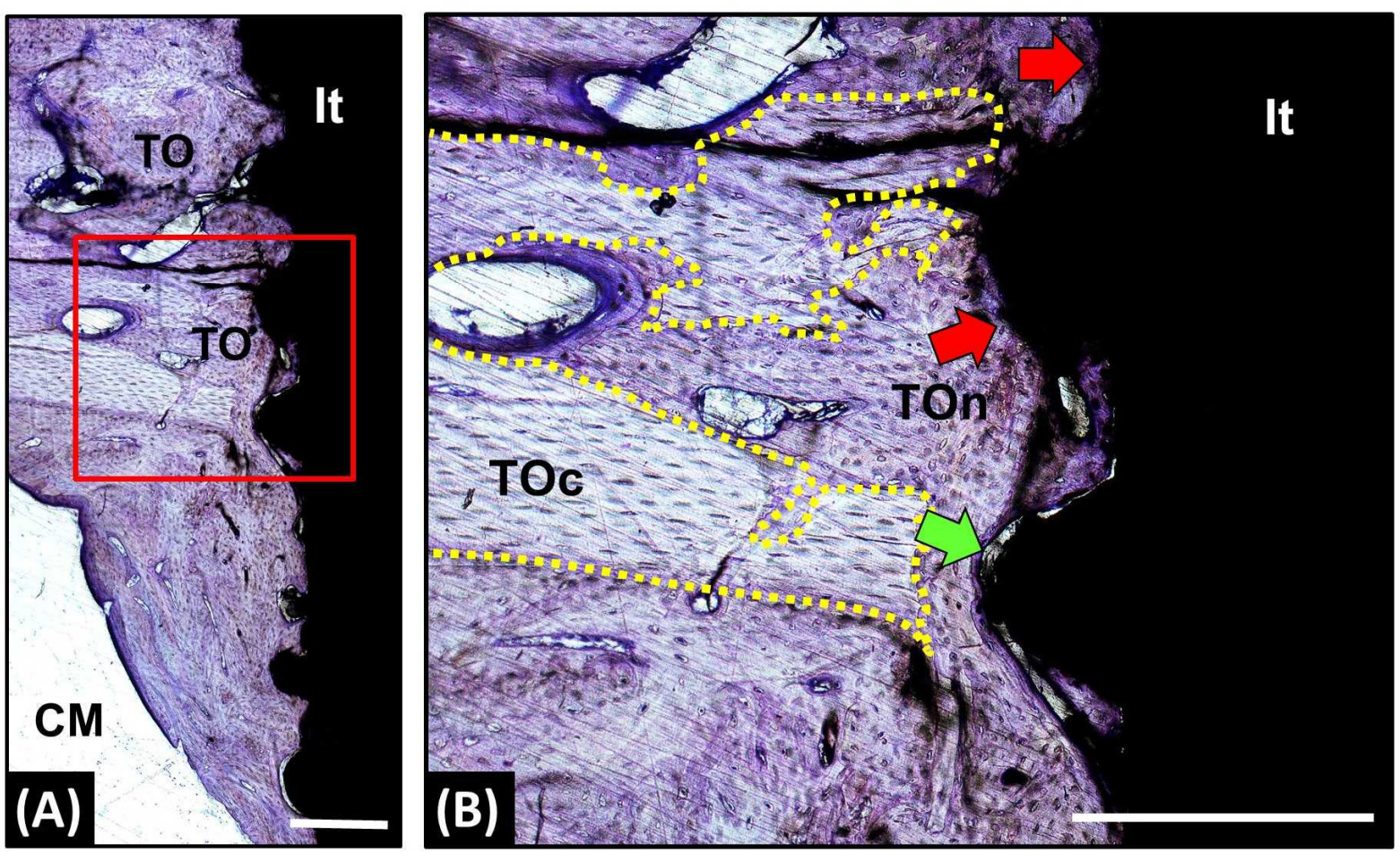

Figura 28: Fotomicrografia do GE-2 após 8 semanas de instalação do implante de titânio com superfície tratada (It): A) Imagem panorâmica da Região cervical do implante (It) mostrando o tecido ósseo (TO) recobrindo a superfície do implante e B) Detalhe da figura na região cortical anterior mostrando intensa reabsorção da cortical óssea (TO, área tracejada amarela) e formação óssea (TOn) recobrindo a superfície do implante (It). Notar as várias áreas de contato osso-implante (seta vermelha) e algumas áreas com interposição de tecido conjuntivo (seta verde). $\mathrm{CM}=$ Canal medular. Barra $=500 \mu \mathrm{m}$. Azul de Toluidina. 


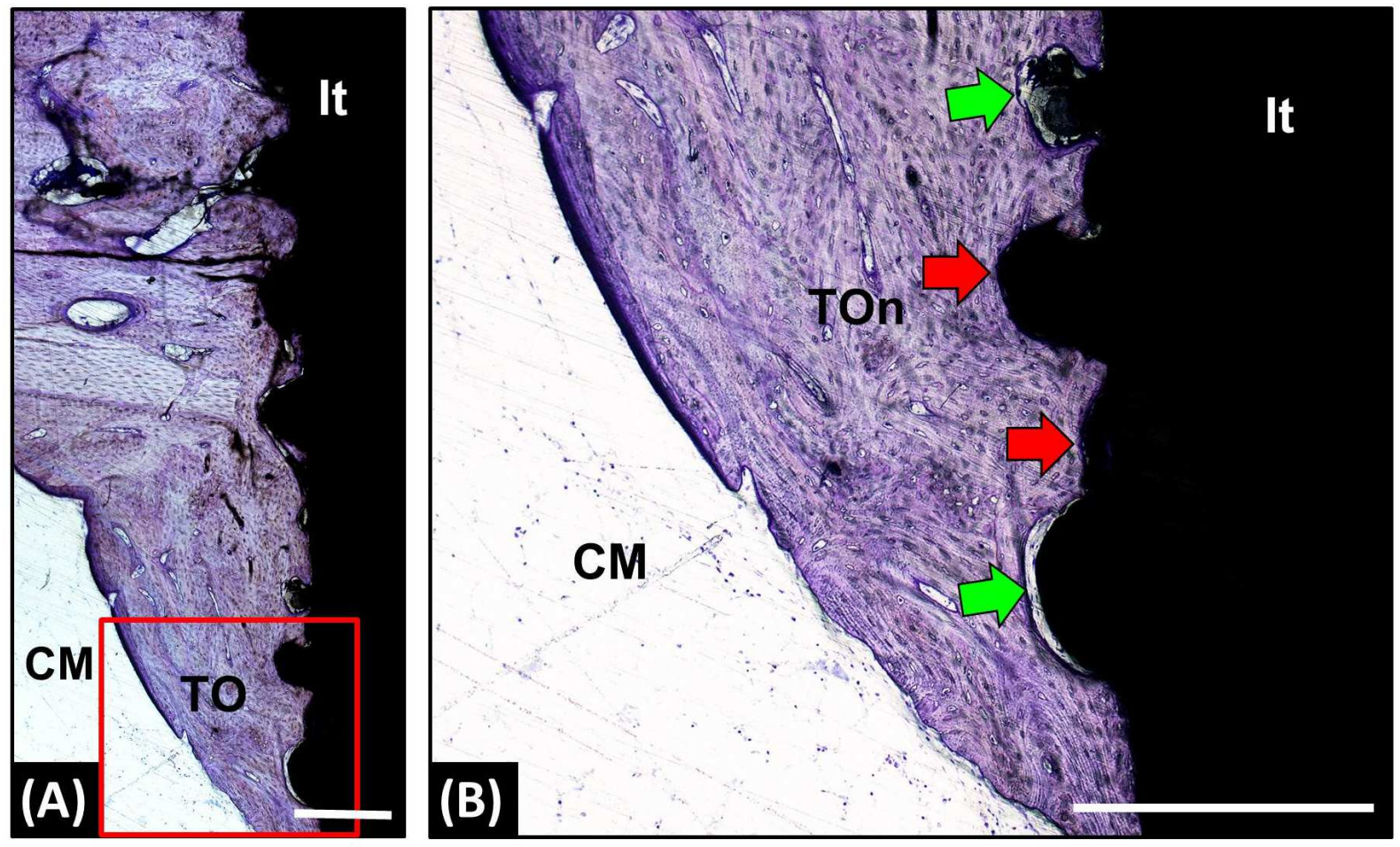

Figura 29: Fotomicrografia do GE-2 após 8 semanas de instalação do implante de titânio com superfície tratada (It): A) Imagem panorâmica da Região cervical do implante (It) mostrando o tecido ósseo (TO) recobrindo a superfície do implante e B) Detalhe da figura anterior mostrando a região medular próxima à cortical recobrindo parcialmente da superfície do implante (It) por tecido ósseo neoformado (TOn). Como o observado na região cortical extensa áreas de contato osso-implante (seta vermelha) e apenas dois pontos com interposição de tecido conjuntivo (seta verde). CM=Canal medular. Barra $=500 \mu \mathrm{m}$. Azul de Toluidina. 


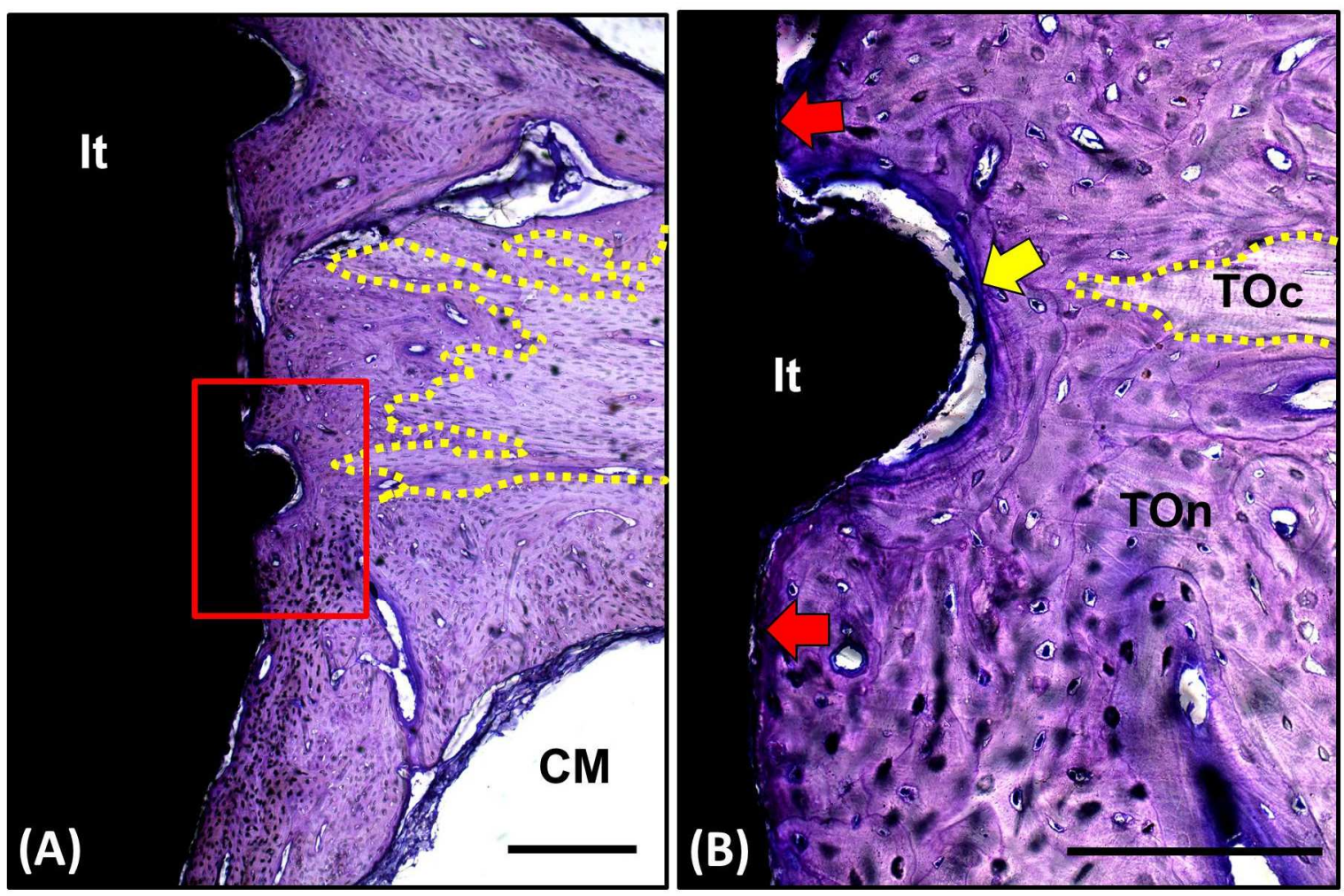

Figura 30: Fotomicrografia do GE-2 após 8 semanas de instalação do implante com superfície tratada (It): A) Imagem panorâmica da região Cortical mostrando intensa reabsorção da cortical óssea (TOc, área tracejada amarela) e de formação óssea (Ton) entre a superfície do implante (It) e a cortical óssea (Toc); B) Detalhe da figura anterior mostrando a remanescente da cortical óssea (TOc) e a extensa formação de osso novo (TOn) em contato com superfície do implante (seta vermelha) ou com interposição por tecido conjuntivo (seta verde). $\mathrm{CM}=$ cortical medular. Barra $=250 \mu \mathrm{m}$. Azul de Toluidina. 


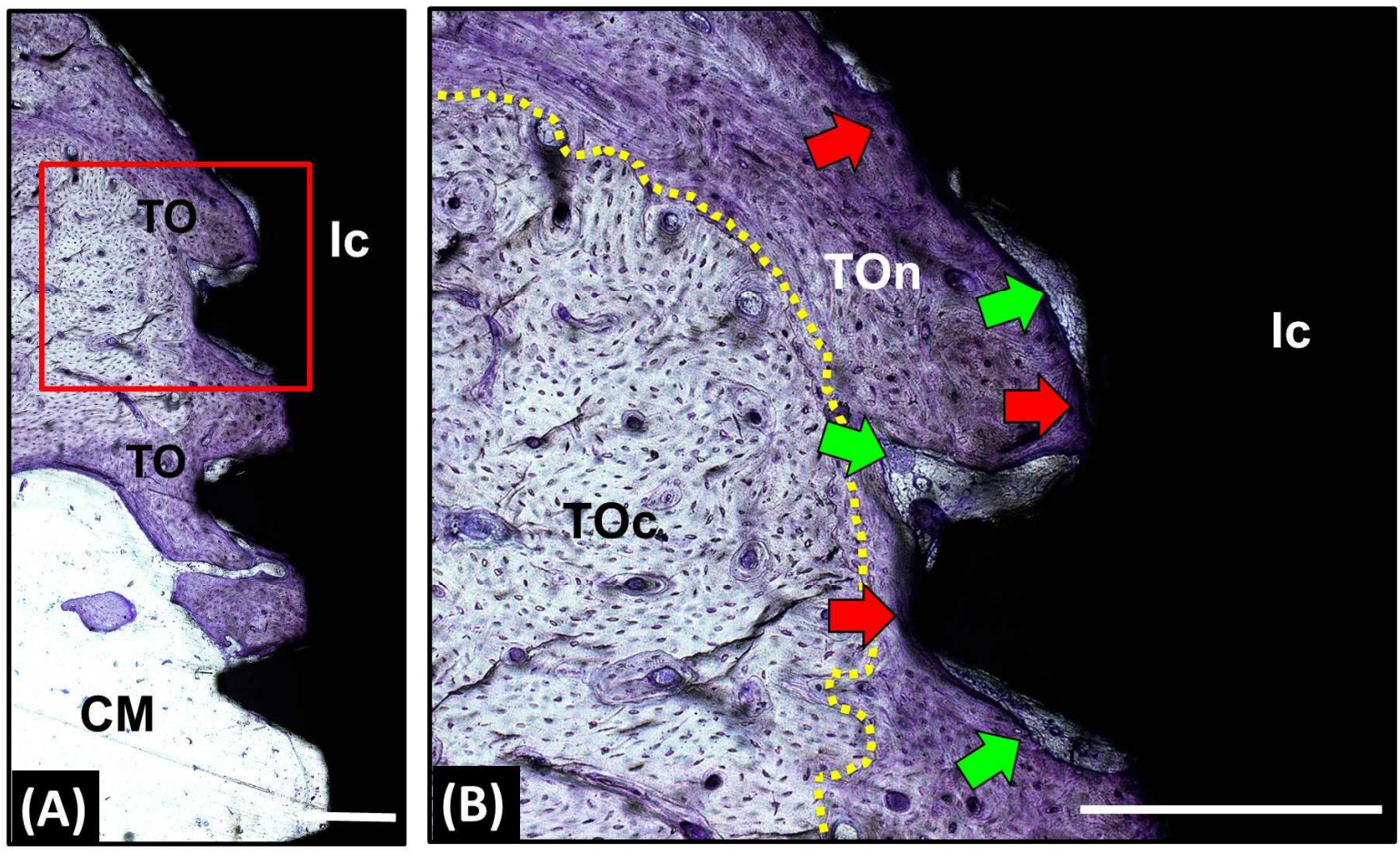

Figura 31: Fotomicrografia do GE-1 após 8 semanas de instalação do implante de Cerâmica (Ic): A) Imagem panorâmica da Região cervical do implante (lu) mostrando o tecido ósseo (TO) recobrindo a superfície do implante e B) Detalhe da figura da cortical óssea mostrando cortical parcialmente íntegra (TO, área tracejada amarela) e a formação óssea (TOn) entre a cortical e o implante (Ic). Notar alguns pontos de contato osso-implante (seta vermelha) e áreas com interposição por tecido conjuntivo (seta verde) recobrindo a superfície do implante (Ic). Notar as várias áreas de contato osso-implante (seta vermelha) e algumas áreas com interposição de tecido conjuntivo (seta verde). $\mathrm{CM}=$ Canal medular. Barra $=500 \mu \mathrm{m}$. Azul de Toluidina. 


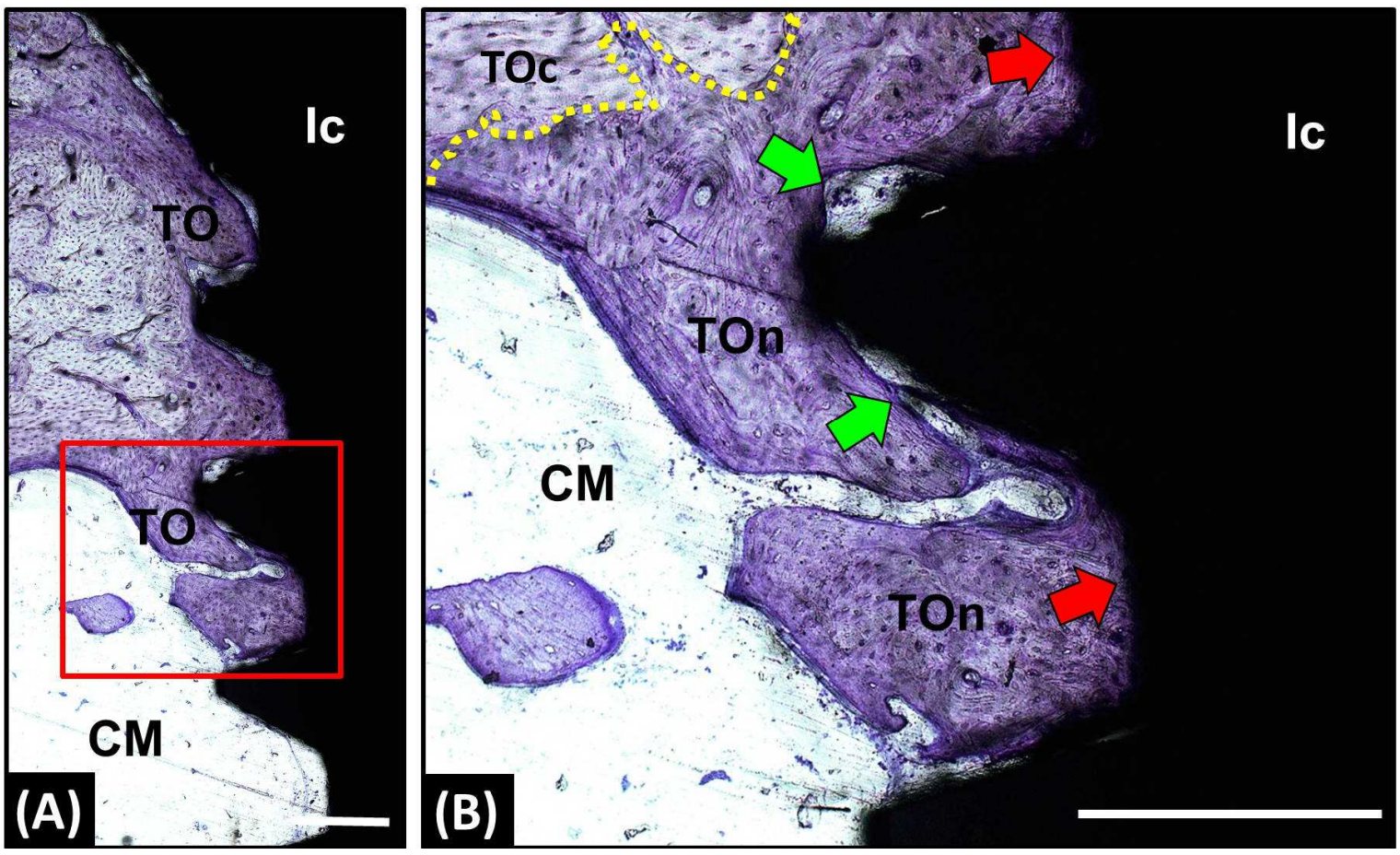

Figura 32: Fotomicrografia do GE-1 após 8 semanas de instalação do implante de Cerâmica (Ic): A) Imagem panorâmica da Região cervical do implante (Ic) mostrando o tecido ósseo (TO) recobrindo a superfície do implante e B) Detalhe da figura anterior na região medular próxima à cortical mostrando recobrimento parcial da superfície do implante (Ic) por tecido ósseo neoformado (TOn). Como o observado na região cortical áreas de contato osso-implante (seta vermelha) e áreas com interposição de tecido conjuntivo (seta verde). $\mathrm{CM}=$ Canal medular. Barra $=500 \mu \mathrm{m}$. Azul de Toluidina. 


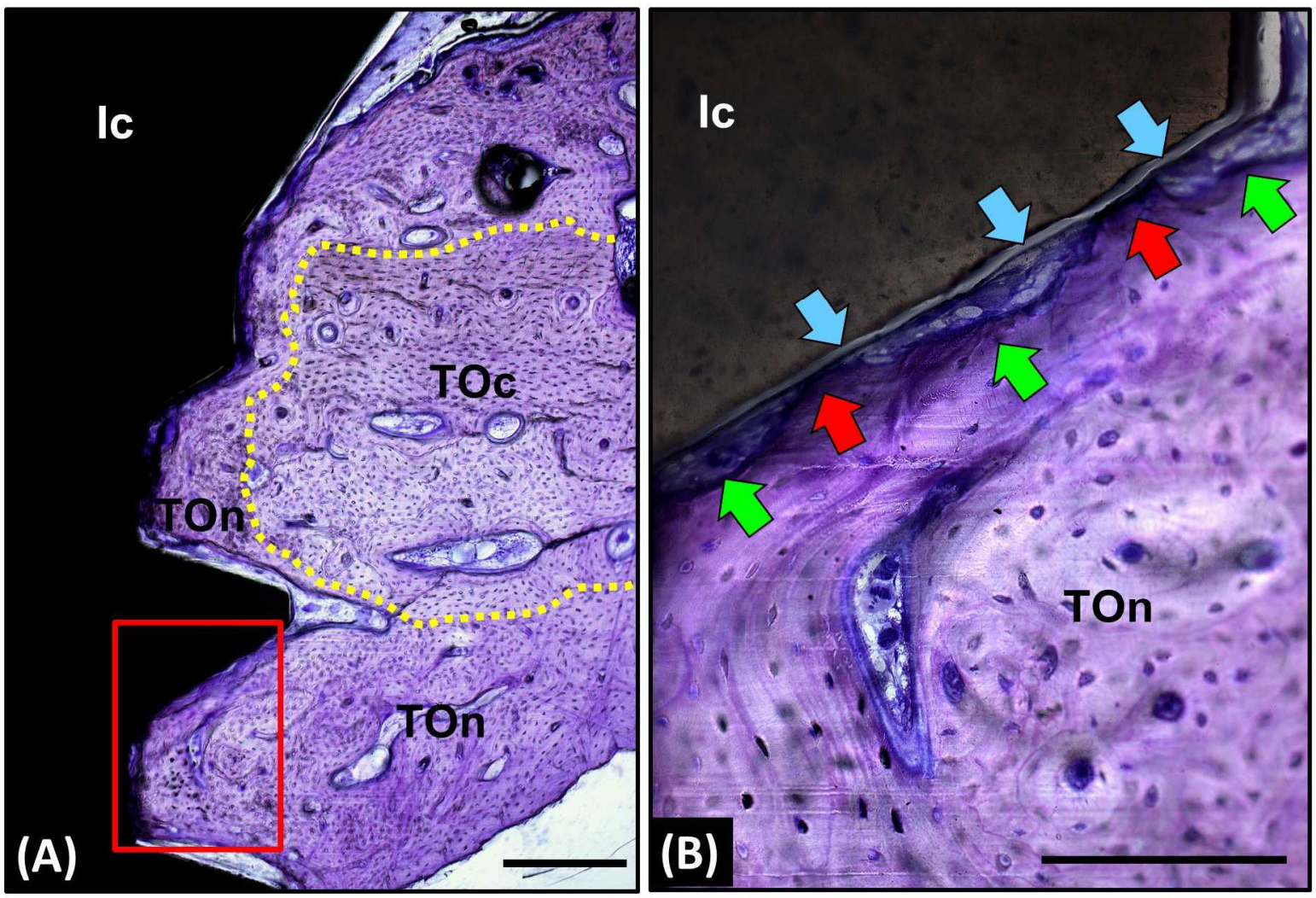

Figura 33: Fotomicrografia do GE-1 após 8 semanas de instalação do implante de Cerâmica (Ic): A) Imagem panorâmica da região Cortical mostrando a cortical óssea (TOc, área tracejada amarela) e de formação óssea (TOn) entre a superfície do implante (Ic) e a cortical óssea (TOc); B) Detalhe da figura anterior mostrando os pontos de contato entre o tecido ósseo neoformado (TOn) e a superfície do implante (Ic) (seta vermelha) e as áreas de interposição por tecido conjuntivo (seta verde). Notar também o degrau (seta azul) que se formou entre o implante e o tecido ósseo durante a obtenção dos cortes. $\mathrm{CM}=$ cortical medular. Barra $=250 \mu \mathrm{m}$. Azul de Toluidina. 


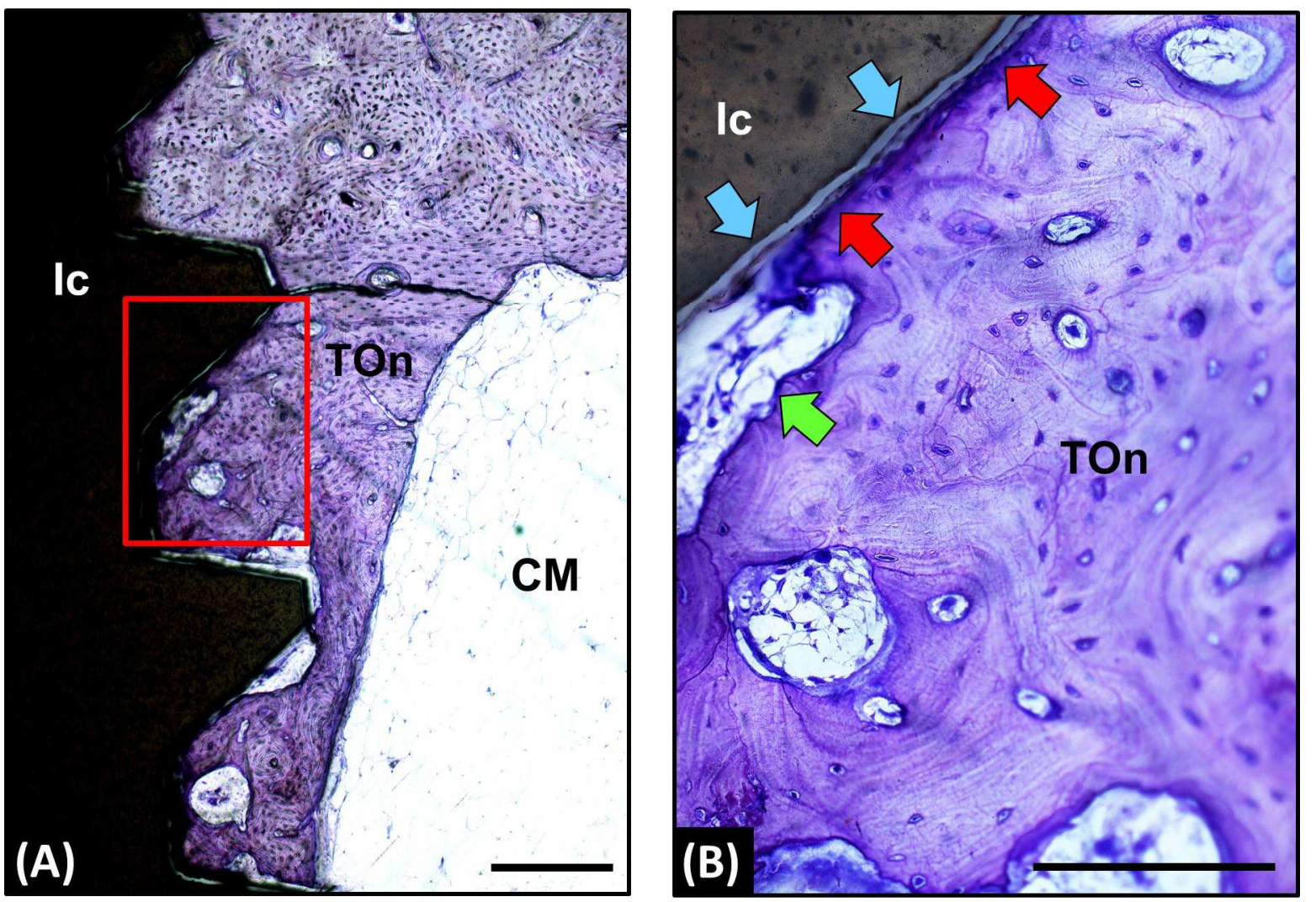

Figura 34: Fotomicrografia do GE-1 após 8 semanas de instalação do implante de Cerâmica (IC): A) Imagem panorâmica da região medular próxima a cortical óssea mostrando a formação óssea (TOn) na superfície do implante (IC); B) Detalhe da figura anterior mostrando as áreas de contato entre o tecido ósseo neoformado (TOn) e a superfície do implante (Ic) (seta vermelha) e as áreas de reabsorção óssea e a interposição por tecido conjuntivo/medular (seta verde). Notar também o degrau (seta azul) que se formou entre o implante e o tecido ósseo durante a obtenção dos cortes. $\mathrm{CM}=$ cortical medular. Barra $=250 \mu \mathrm{m}$. Azul de Toluidina. 



\subsubsection{Percentual BIC e BA - comparação entre sexo}

Os dados obtidos para o percentual de contato osso e implante - BIC e da área de tecido ósseo - BA da região cortical e medular estão apresentados, respectivamente, nas Tabelas 12 e 13 e nas figuras 27 e 28 .

Tabela 12: Percentual de contato osso-implante - BIC (\%) nos diferentes grupos - Comparação entre sexos utilizando Teste de Mann-Whitney U.

BIC (\%)

\begin{tabular}{lccc}
\hline Grupos & Fêmea & Macho & p \\
\hline GE1 - Cêramica & $39,68 \pm 11,48$ & $44,53 \pm 13,38$ & 0,441803 \\
\hline GE2 - Titânio tratado & $46,43 \pm 21,50$ & $41,99 \pm 18,00$ & 0,885714 \\
\hline GC - Titânio usinado & $53,76 \pm 11,98$ & $55,59 \pm 14,47$ & 1,000000 \\
\hline
\end{tabular}

Tabela 13: Percentual de área óssea - BA (\%) nos diferentes grupos - Comparação entre sexos utilizando Teste de Mann-Whitney $U$.

BA (\%)

\begin{tabular}{lccc}
\hline Grupos & Fêmea & Macho & p \\
\hline GE1 - Cêramica & $43,11 \pm 10,22$ & $51,59 \pm 13,25$ & 0,064957 \\
\hline GE2 - Titânio tratado & $46,24 \pm 13,36$ & $50,08 \pm 20,24$ & 1,000000 \\
\hline GC - Titânio usinado & $70,93 \pm 1,56$ & $61,43 \pm 16,53$ & 1,000000 \\
\hline
\end{tabular}




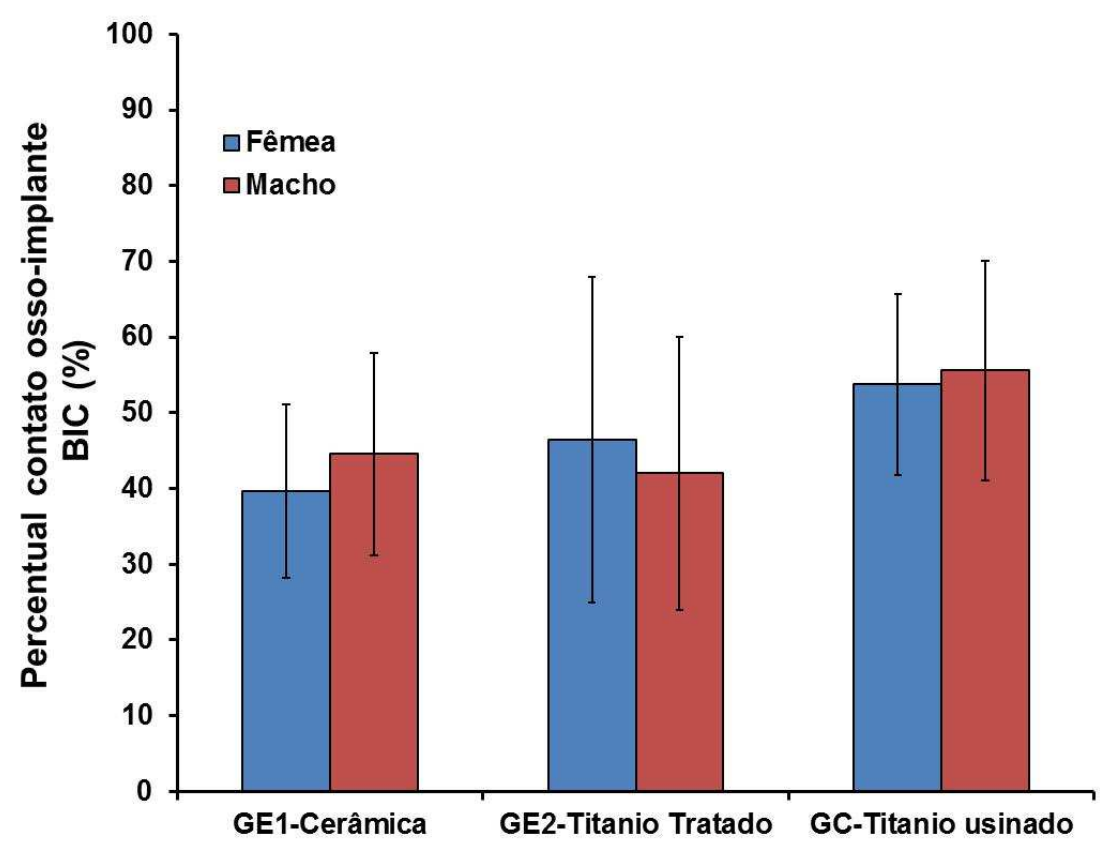

Figura 35 - Gráfico da média e do desvio padrão do BIC (\%) obtido para machos e fêmeas de cada grupo.

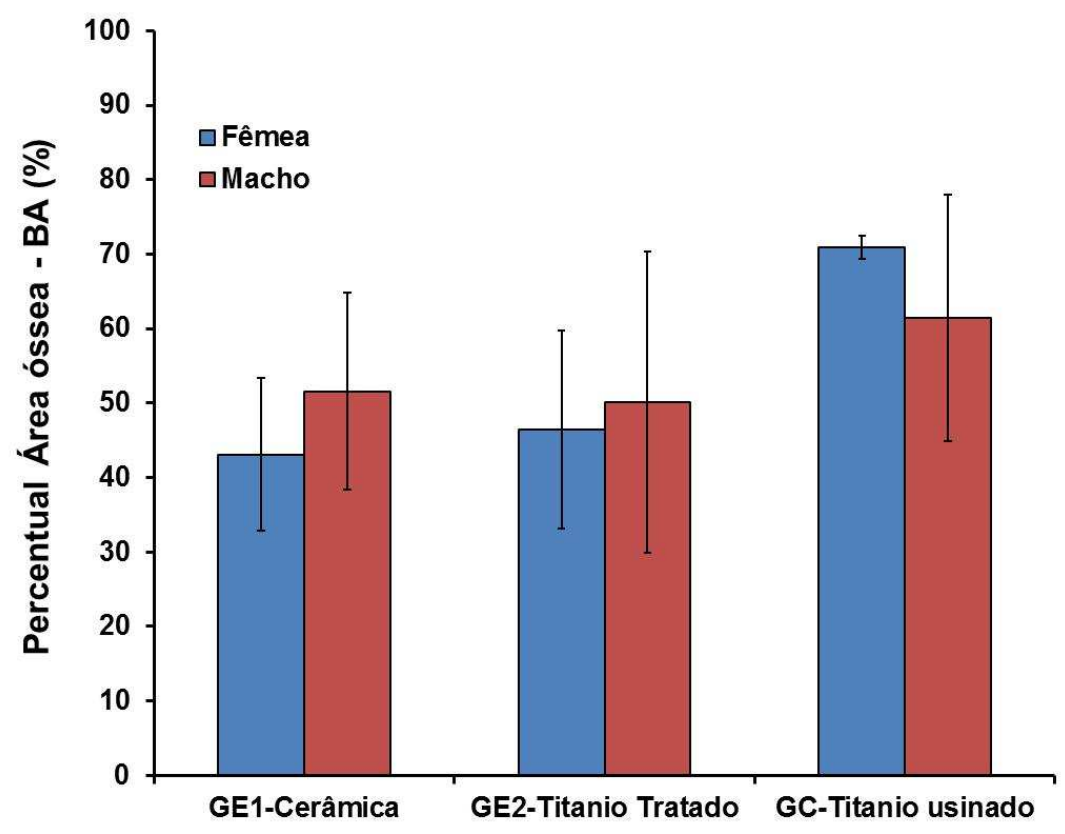

Figura 36 - Gráfico da média e do desvio padrão do BA (\%) obtido para machos e fêmeas de cada grupo. 
A análise das Tabelas 12 e 13 e das Figuras 27 e 28 bem como da análise estatística dos dados mostram que entre os sexos não ocorreram diferenças quanto ao percentual de contato osso-implante - BIC e do percentual de área de tecido ósseo próximo a superfície do implante- BA.

\subsubsection{Percentual BIC e BA - comparação entre grupos}

Os dados obtidos para o BIC e BA para cada grupo na região Cortical, Medular e de ambas as regiões estão apresentados, respectivamente, nas Tabelas 14 e 15 e nas Figuras 29 e 30. Como não ocorreram diferenças estatísticas entre machos e fêmeas para estes parâmetros os grupos GC, GE-1 e GE-2 foram compostos por machos e fêmeas indistintamentes.

Tabela 14: Percentual contato osso-implante - BIC (\%) na região cortical, medular e cortical + medular - Comparação entre grupos utilizando ANOVA a um critério e post-hoc teste de Tukey.

\begin{tabular}{|c|c|c|c|c|}
\hline \multirow{2}{*}{ Regiões } & \multicolumn{4}{|c|}{ BIC (\%) } \\
\hline & $\begin{array}{c}\text { GE-1 - } \\
\text { Cêramica }\end{array}$ & $\begin{array}{c}\text { GE-2 - Titânio } \\
\text { tratado }\end{array}$ & $\begin{array}{c}\text { GC - Titânio } \\
\text { usinado }\end{array}$ & "p" \\
\hline Cortical & $58,83 \pm 18,67$ & $63,23 \pm 14,24$ & $61,59 \pm 19,54$ & 0,526057 \\
\hline Medular & $35,23 \pm 11,35^{\mathrm{B}}$ & $26,83 \pm 24,36^{B}$ & $47,76 \pm 7,98^{A}$ & 0,015116 \\
\hline Cortical+Medular & $44,53 \pm 13,38$ & $44,21 \pm 18,51$ & $54,67 \pm 12,33$ & 0,129315 \\
\hline
\end{tabular}

Letras diferentes indicam diferença significante $(p<0,05)$.

Tabela 15: Percentual de área óssea - BA (\%) na região cortical, medular e cortical + medular Comparação entre grupos utilizando ANOVA a um critério e post-hoc teste de Tukey.

\begin{tabular}{|c|c|c|c|c|}
\hline \multirow[b]{2}{*}{ Regiões } & \multicolumn{4}{|c|}{ BA (\%) } \\
\hline & $\begin{array}{c}\text { GE-1 - } \\
\text { Cêramica }\end{array}$ & $\begin{array}{c}\text { GE-2 - Titânio } \\
\text { tratado }\end{array}$ & $\begin{array}{l}\text { GC - Titânio } \\
\text { usinado }\end{array}$ & “p” \\
\hline Cortical & $64,64 \pm 18,46^{\mathrm{B}}$ & $72,82 \pm 13,34^{A}$ & $85,11 \pm 10,15^{A}$ & 0,012276 \\
\hline Medular & $38,54 \pm 15,01^{A}$ & $23,50 \pm 23,03^{B}$ & $47,25 \pm 14,90^{A}$ & 0,029162 \\
\hline Cortical+Medular & $51,59 \pm 13,25^{\mathrm{B}}$ & $48,16 \pm 16,01^{B}$ & $66,18 \pm 11,99^{A}$ & 0,006850 \\
\hline
\end{tabular}


Letras diferentes indicam diferença significante $(p<0,05)$.

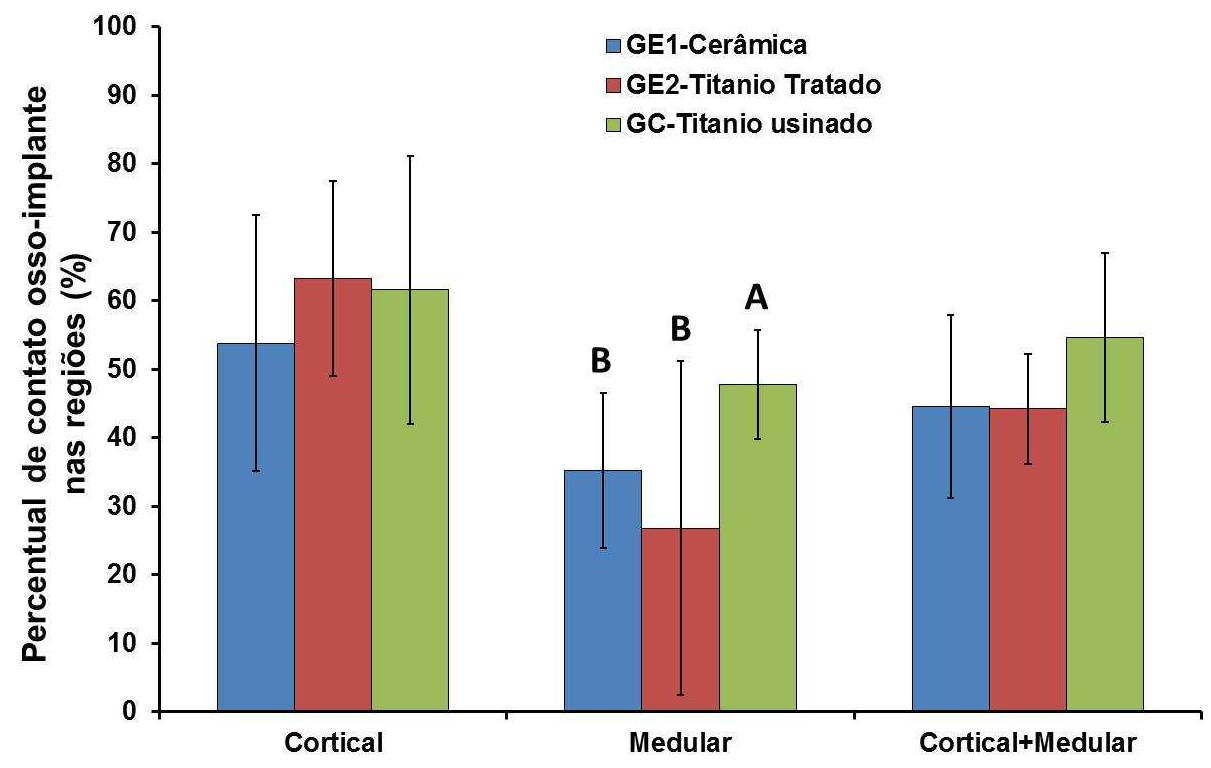

Figura 37 - Gráfico da média e do desvio padrão do BIC (\%) obtido nas diferentes regiões nos diferentes grupos. Letras diferentes $p<0,05$ entre grupos por região.

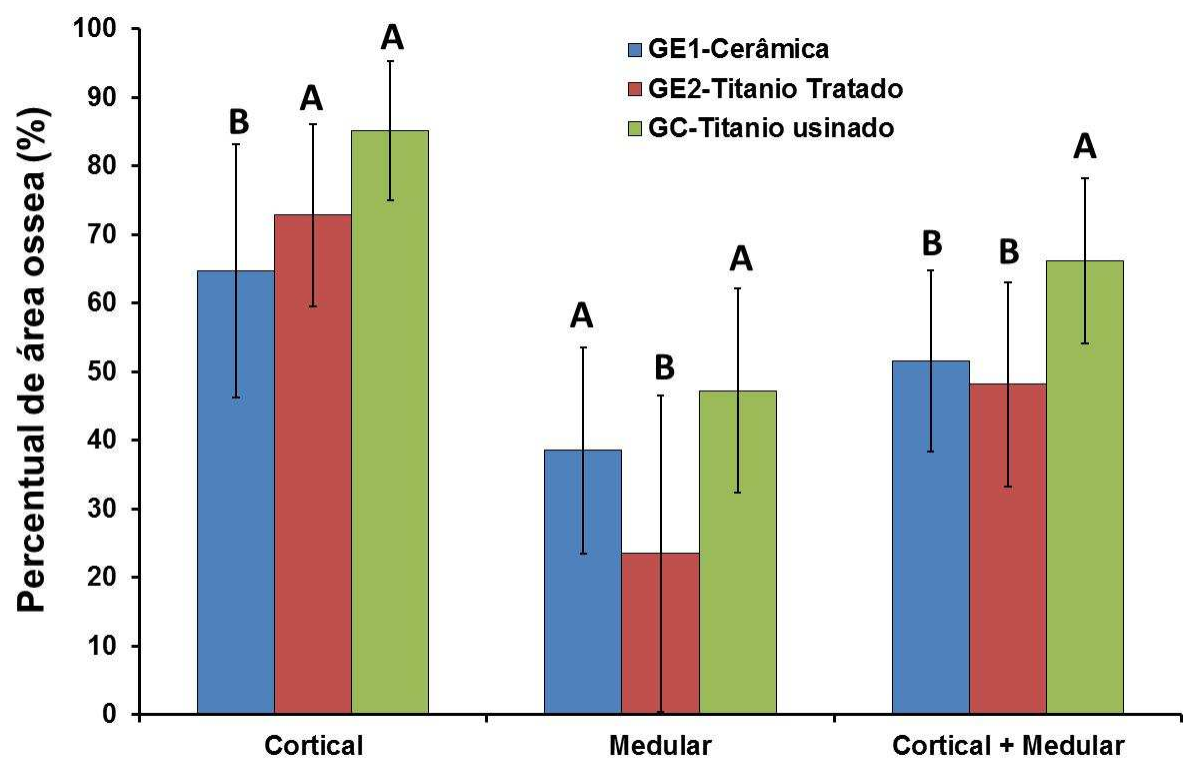

Figura 38 - Gráfico da média e do desvio padrão do BA (\%) obtido nas diferentes regiões nos diferentes grupos. Letras diferentes $p<0,05$ entre grupos por região. 
A análise das Tabelas 14 e 15 e das Figuras 29 e 30 bem como da análise estatística dos dados mostram que:

a) o BIC tanto na região Cortical e Cortical+Medular não apresentaram diferenças estatisticamente significantes entre os grupos. Porém, comparando apenas a região Medular, no GC foi 0,54 vezes maior em relação aos demais grupos.

b) o BA na região Cortical do grupo GE-2 e GC foi 0,22 vezes maior em relação ao GE-1, enquanto que, na Medular o BA no GE-2 foi 0,56 vezes menor em relação ao GE-1 e GC. Analisando ambas as regiões, cortical+medular, o BA no $\mathrm{GC}$ foi 0,33 vezes maior em relação aos demais grupos. 




\section{DISCUSSÃO}

Com o aumento da longevidade, é crescente a instação de implantes para ancoragem de peças protéticas melhorando a estética e a função mastigatória. Visando a redução dos custos e melhoria da capacidade de osseointegração dos implantes dentários sem afetar a estética dento-gengival solicitamos a empresa Riellens Ltda (Vargem Grande Paulista - SP - Brasil) a confecção de um implante de cerâmica a base de zirconia reforçada com ítria com superfície usinada e sem qualquer tratamento para ser avaliado in vivo a sua capacidade de osseointegração. Vale salientar que, esse tipo de cerâmica é amplamente utilizada na produção de prótese de quadril (PICONI e MACCAURO, 1999), e devido a suas qualidades mecânicas, propriedades ópticas e menor adesividade do biofilme (RIMONDINI et al., 2002, SCARANO et al., 2004) vem despertando interesse como implante osseointegrável na area odontológica.

Como comparativo utilizamos da mesma empresa, e com as mesmas características anatômicas, o implante de titânio usinado sem qualquer tratamento de superfície. Por outro lado, um dos fatores determinantes para que ocorra a osseointegração diz respeito à superfície dos implantes dentários que está diretamente relacionada às propriedades físico-químicas das superfícies. Assim pesquisadores e indústrias têm buscado diferentes métodos de tratamento de superfície alterando as forças interfaciais, molhabilidade, rugosidade, energia e a capacidade de adsorver as moléculas aumentando a propriedade de osteointegração (STANFORD, 2010). O titânio comercialmente puro é um material bioinerte e atualmente, um dos tratamentos de superfície visa proporcionar uma bioatividade à superfície do implante por meio de jateamento de micro ou nanopartículas de materiais bioativos como fosfatos de cálcio e biovidros, promovendo assim uma adesão bioquímica. No atual trabalho, tivemos a oportunidade de avaliar a resposta biológica de um implante de superfície tratada com jateamento RBM (RESORBABLE BLAST MEDIA - jateamento da superfície do implante com partículas reabsorvíveis) de Brushita, fosfato de cálcio bioativo reabsorvível (CaP) que foi cedido gentilmente pela Globtek Implant Systen - Coréia. 
Esse tipo de tratamento de superfície RBM oferece uma rugosidade $\mathrm{Ra}$ 1.2 1.5 proporcionando uma osseointegração mais rápida e segura (POULOS et al., 2011).

\section{Modelo experimental}

Para avaliar as características de osseointegração desses implantes optamos por utilizarmos um modelo experimental em tíbias de coelhos (Oryctolagus cuniculus) bem estabelecido na literatura (LIU et al., 2005; MAETZU et al., 2003; EGENI et al., 1996; ROBERTS et al., 1984) devido à correlação existente entre a fisiologia de coelhos e de humanos (ROBERTS et al., 1984). Porém, as limitações deste estudo devem ser mantidas em mente durante a extrapolação do comportamento dos testes em animais para a situação clínica com humanos. A maior diferença está nas dimensões do implante em relação ao organismo do coelho e em relação ao organismo dos humanos (WOODMAN et al., 1984b). As dimensões do material testado em relação os sistema biológico dos coelhos podem ter grande influência sobre os resultados (GIOKA et al., 2004).

Por termos utilizados um implante não comercializado e em fase de caracterização, optamos por avaliar a osseointegração somente ao término de 8 semanas de implantação, conforme utilizado no Departamento de Anatomia do Instituto de Ciências Biomédicas da USP-SP, coordenado pelo prof. Dr. Bruno Konig Júnior e pel Prof Dr. Marcelo José Carbonari do IPEN, bem como os tempos de aplicação e quantidade a ser aplicada para os marcadores de deposição óssea fluorescentes (RAHN, 1976; KÖNIG et al., 2002). Além disso, a seleção dos tempos de análise levou em consideração o estudo de Roberts et al. em 1984, que estabeleceu que o metabolismo de coelhos é 3 vezes mais rápido que 0 metabolismo de humanos. Por exemplo, o tempo de remodelamento ósseo ("turnover" ósseo) é de 18 semanas em humanos e de aproximadamente 6 semanas em coelhos. Desta forma, é aceitável considerar que as 8 semanas de implantação, que compreendeu o período deste experimento em coelhos equivalem a, aproximadamente, 24 semanas em humanos, o que seria o período médio necessário para a osseointegração estar completamente estabelecida para a situação clínica em humanos.

Vale salientar que os critérios mais utilizados para avaliar a osseointegração 
dos implantes é a proporção de osso em contato direto com o implante (BIC) que é dada pela percentagem de osso encontrado em contato com a superfície do implante (BUTCHER et al., 2006, BRANEMARK et al., 1997, BRANEMARK et al., 1998; JUNG et al., 2008; DE MAEZTU et al., 2008; RAHMANI et al., 2005; LOURENÇO, 2002; THERHEYDEN et al., 1999; SCHWARZ et al., 2007, YOU et al., 2007), e a proporção da área de osso presente na região próxima às roscas, que é dada em percentagem com relação à área total analisada (BRANEMARK et al., 1997; BRANEMARK et al., 1998; LOURENÇO, 2002; THERHEYDEN et al., 1999; SCHWARZ et al., 2007). Porém, a diversidade de BIC e BA encontrado na literatura residem no tamanho e formato das roscas dos implantes, idade dos animais, região implantada (proximal ou distal da tíbia) e na área avaliada (cortical ou medular ou cortical + medular) e no período de tempo avaliado. Por isso fomos cautelosos ao comparar os dados numéricos com os obtidos em outros trabalhos.

Com relação aos marcadores de neoformação óssea para análise na microscopia confocal, informamos que, embora seja amplamente difundina na literatura vigente, pois permite avaliar em um único período a quantidade de deposição óssea com o decorrer do tempo e comparar entre os grupos (NISHIKAWA et al., 2006; SUZUKI, AOKI e OHYA, 1997; KOO et al., 2004; YOSHIMOTO et al., 2004), poucos são os trabalhos que utilizaram esta técnica para avaliar o perfil de deposição óssea associada aos implantes de zircônia ou a Brushita. Além disso, os tempos de aplicação/incorporação dos marcadores variam na literatura. Assim, nos atentamos aos resultados obtidos em nosso trabalho sem fazer menções a outros, utilizando como ferramenta para avaliarmos a evolução/dinâmica da osseointegração dos implantes observados nos morfológicos, que são estáticos (56 dias pós-implantação) como veremos a seguir.

Optamos também por trabalhar com animais de ambos os sexos, na mesma proporção, o que em função da idade em que os coelhos sofreram as cirurgias (9 a 12 meses) tal fator não deveria interferir nos resultados conforme Profa. Dra. Sheila Canavesse Rahal da Faculdade de Medicina Veterinária e Zootecnica da UNESPBotucatu, o que foi confirmado estatisticamente nos nossos resultados quanto ao percentual de marcadores de deposição óssea fluorescentes, o BIC e o BA. 
Morfologicamente, após as 8 semanas de implantação de todos os grupos, em ambos machos e fêmeas, a região cervical de todos os implantes mostravam circundados por tecido ósseo compacto, sendo que, mais de $50 \%$ de sua superfície apresentava em contato direto com o tecido ósseo e o restante havia interposição por fina camada de tecido conjuntivo. Nos grupos GC e GE-1 praticamente não apresentaram sinais de reabsorção da cortical óssea remanescente, levando a formação de uma densa faixa de tecido ósseo maduro ou lamelar entre a cortical e o implante. Esse padrão similar de deposição óssea também foi observado quanto as percentual de marcadores fluorescentes. O BA no grupo GE-1 $(51,59 \%)$ foi 0,22 vezes menor em relação $\mathrm{GC}(66,18)$, embora o BIC não tenha apresentado diferenças estatisticamente significantes. Quando avaliamos os marcadores de deposição óssea observamos que na região da cortical o percentual de marcação foi similar entre os grupos GE-1 e GC, tanto para Tetraciclina (GE1 = 28,92 versus GC $=27,67$ ), Alizarina $(\mathrm{GE}-1=15,79$ versus $\mathrm{GC}=18,81$ ) e calceína $(\mathrm{GE}-1=7,32$ versus $\mathrm{GC}=8,78)$. Porém na região medular a incorporação principalmente para tetraciclina foi substancialmente 0,28 vezes menor no grupo G1 (18,08\%) em relação ao GC $(25,06 \%)$. Estes dados demonstra a ocorrência de um pequeno atraso no processo de formação/maturação óssea no GE-1 em relação ao GC, ou seja, a completa osseointegração com a zircônia se estabele um pouco mais tardiamente que 0 titânio.

\section{Neoformação óssea e BIC}

Utilizando o mesmo modelo experimental Albrektsson et al. (1984) estudaram a ultra-estrutura do osso adjacente ao zircônio e titânio revestido com policarbonato 6 meses após a inserção no osso. Os autores não observaram interposição de tecido mole na interface do implante-osso e sem quaisquer reações teciduais adversas, concluindo que ambos os metais são bem aceitos pelo organismo, embora o titânio tenha apresentado formação de uma camada mais espessa de proteoglicanos em torno dos implantes. Neste mesmo modelo e período experimental Thomsen et al (1987) observaram a formação de tecido ósseo compacto/lamelar na superfície dos implantes de titânio e zircônia apresentando similares BIC (media de $41 \%$ ) e BA (média de $60 \%$ ). 
Dubruille et al. (1999) compararam o BIC de 3 diferentes implantes dentários (zircônia, alumina e titânio) instalados em mandíbulas de cães por 10 meses. Os autores encontraram valores superiores de BIC para a alumina (68\%) e zircônia $(64,4 \%)$ em relação ao titânio $(54 \%)$, no entanto, esses valores não diferiram estatisticamente. Panorama esse semelhante aos nossos resultados para o osso cortical (em 8 semanas), uma vez que encontramos valores muito próximos aos dos autores (aproximadamente $60 \%$ de contato osso implante) em todos os grupos (cerâmica e titânio), além de não encontrarmos diferença estatística entre os grupos.

No trabalho de Hoffmann e colaboradores (2008), os autores avaliaram comparativamente a neoformação óssea precoce ao redor de implantes de zircônia e titânio implantados em fêmures de coelhos, nos períodos experimentais de 2 e 4 semanas. Os resultados desses autores mostraram uma maior aposição óssea no grupo que recebeu os implantes de zircônia (54\% - 55\%) quando comparado ao grupo com implantes de titânio (42\% - 52\%) em 2 semanas. No entanto, no período posterior de avaliação (4 semanas) os resultadores se inverteram, com: titânio (68\% - 91\%) e zircônia (62\% - 80\%). Essa descrição realizada pelos autores (HOFFMANN et al., 2008) apresenta alguma similaridade com nossos resultados de osso cortical, uma vez que encontramos resultados de maior marcação para tetraciclina (períodos de 14 e 21 dias ou 2 e 3 semanas) no grupo com implante de cerâmica comparado ao titânio, mesmo não sendo significante. Entretanto, essa relação de marcação se inverte nos períodos posteriores (e outros marcadores: alizarina - 28 e 35 dias calceína - 42 e 49 dias), indicando que a cerâmica apresenta uma melhor resposta num prazo curto, quando comparado ao titânio, mas em prazos mais longos (acima de 4 semanas) o titânio apresenta valores superiores de aposição óssea.

Outro trabalho que corrobora com a discussão anterior é o artigo de Langhoff et al. (2008). Neste trabalho os autores usaram diferentes materiais (incluindo titânio e zircônia) e design de implantes, instalados em crista ilíaca de ovelhas. Avaliando o BIC nos períodos de 2, 4 e 8 semanas. Todos os materiais testados apresentaram resultados finais (em 8 semanas) de BIC próximos à $80 \%$. Entretanto, vale destacar que o implante de zircônia apresentou o maior valor de BIC $(77 \%)$ no período mais curto (2 semanas), enquanto os outros implantes apresentaram valores inferiores à $61 \%$ no mesmo período (2 semanas). 
Já Scarano et al. (2003) avaliou a osseointegração após 4 meses de instalação dos implante e observaram também uma grande quantidade de osso neoformado maduro e com poucos espaços medulares em íntimo contacto com as superfícies cerâmicas de zircônia, porém como se tratava de um período intermediário de osseointegração, muitos osteoblastos ainda estavam presentes na superfície da zircônia nas porções mais coronais e apical do implante, mostrando que os implantes de zircônia são altamente biocompatíveis e osteocondutores. Mais recentemente, Shin et al. (2011) após 6 semanas de instalação dos implantes também não observaram diferenças estatisticamente significativas entre a zircônia e titânio em termos de BIC (Titanio=35,8\% e Zirconia 26\%), teste de remoção ao torque e avaliação microtomográfica, porém, ○ BA foi maior para o titânio (titânio $81 \%$ versus zircônia $=72 \%$ ) e os níveis de mineralização avaliados após aplicação da calceína na 4 semanas de instalação foram superiores no grupo da Zircônia (Zircônia $40 \%$ versus titânio 15\%), sendo reportado pelos autores que a resposta óssea aos implantes de zircônia é similar aos do tiânio. Já, Park et al. (2012) avaliou a osseointegração apos 4 semanas de instalação dos implantes de titânio usinado, zirconia usinada, e zircônia de superfície rugosa obtendo. BICs maiores para os implantes de Zircônia (usinada $=61,63 \%$ e tratada $=64,42 \%$ ) em relação ao titânio usinado $(42,54 \%)$ e para o teste de remoção ao torque superior para a zircônia rugosa $(64,35 \mathrm{~N} / \mathrm{cm})$, seguido pela zircônia usinada $(44,27 \mathrm{~N} / \mathrm{cm})$ e menor para 0 titânio usinado $(20,56 \mathrm{~N} / \mathrm{cm})$, mostrando uma superioridade da ossoeintegração nos implantes de zircônia em relação ao titânio.

Outros modelos experimentais como o de Möller et al. (2012) em crânio de porcos domésticos sugerem que um pequeno retardo na osseointegração da zircônia em relação ao titânio, como o observado em nosso trabalho. Na fase inicial de osseointegração (4 semanas) uma tendência de menor BIC para a zircónia $(59,3 \%)$ em relação ao titânio $(64,1 \%)$ seguindo o mesmo padrão na fase de estabelecimento da osseointegração (12 semanas), zircónia $(67,1 \%)$ e titânio $(73,6 \%)$. Embora o animal e a área de implantação tenham sido diferentes ao do nosso trabalho, a tendência de retardo na ósseointegração dos implantes de zircônia em relação ao titânio também foi similar ao observado no atual trabalho. 
Diferentemente ao observado no GE-1 e GC, no GE-2 ocorreu intensa reabsorção da cortical óssea remanescente próxima ao implante, gerando um extenso espaço entre a superfície do implante que foi preenchido por novo tecido ósseo, porém, mais imaturo em relação aos do GE-1 e GC. Este intenso processo de reabsorção e de formação óssea observado no GE-2 ao longo das 8 semanas foi confirmado pelo elevado percentual de marcadores ósseos fluorescentes na cortical e medular, que foi em média 0,43 vezes (Tetraciclina), 0,95 vezes (Alizarina) e 0,82 vezes (calceína) maiores em relação aos demais grupos GE-1 e GC, sendo que, a incorporação destes marcadores se referem respectivamente ao período inicial (14 a 28 dias), intermediário (28 a 42 dias) e final/estabelecimento da osseointegração (49 a 56 dias).

Algumas diferenças de resultados, em especial ao BIC em experimentos in vivo (animal), são discutidos e justificados por alguns autores devido aos diferentes designs experimentais escolhidos. Alguns dos trabalhos já citados anteriormente usaram modelos animais diferentes (fêmur ou tíbia de coelhos, crista ilíca de ovelhas, tíbia de minipig, mandíbula de cão, etc) em tempos diferentes $(2,4,8,10$ e/ou 12 semanas), impedindo assim a comparação direta de valores de BIC ou dados morfométricos (DUBRUILLE et al., 1999; SCARANO et al., 2003; DEPPRICH et al., 2008a; LANGHOFF et al., 2008; HOFFMANN et al., 2008; GAHLERT et al., 2012). Por outro lado, mesmo respeitando cada modelo experimental usado, a maioria dos trabalhos tem convergido em apresentar conclusões no qual a cerâmica (zircônia, modificada ou não com óxidos) demonstra valores muito parecidos com o titânio em relação a resposta biológica dos tecidos no qual foram implantados (DUBRUILLE et al., 1999; SCARANO et al., 2003; DEPPRICH et al., 2008a; LANGHOFF et al., 2008; HOFFMANN et al., 2008; ÖZKURT \& KAZAZOGLU, 2011; REGISH et al., 2013). Nesse sentido, nosso trabalho apresenta, além de coerência com os dados da literatura (BIC e neoformação óssea), um adicional que é a semelhança desses resultados entre os sexos. Ressaltamos que poucos trabalhos da literatura tem apresentado estudos recentes testando o desempenho desses materiais nos dois sexos.

O foco de muitos outros trabalhos em comparar a zircônia e titânio, tem apresentado quase sempre o mesmo resultado em análises in vivo (BIC) 
(DEPPRICH et al., 2008a; ÖZKURT \& KAZAZOGLU, 2011; REGISH et al., 2013; ASSAL, 2013) e in vitro (proliferação e adesão celular) (DEPPRICH et al., 2008b; ÖZKURT \& KAZAZOGLU, 2011; ASSAL, 2013): semelhança entre os achados dos dois materiais. Além de se destacar a qualidade estética propocionada pela cerâmica (ANDREIOTELLI et al., 2009; ÖZKURT \& KAZAZOGLU, 2011; REGISH et al., 2013).

Comparativamente, Fontana et al. (2011) avaliaram a superfície do implante revestido Ca-P e comparou com a superfície porosa de óxido de titânio 2, 4 e 9 semanas após a instalação dos implantes. A análise histomorfometrica em termos de BIC e do teste de remoção ao torque não apresentou diferenças significativas entre os implantes nos períodos de 2 e 4 semanas, porém, no período de 9 semana os implantes revestido de Ca-P apresentava valores de remoção ao torque $(20,16 \mathrm{~N} / \mathrm{cm}$ versus $23,45 \mathrm{~N} / \mathrm{cm})$ e BIC $(26,61 \%$ versus $39,12 \%)$ menores em relação ao de oxido de titânio. Contraditoriamente, Suh et al. (2007) estudaram os efeitos de um revestimento de cálcio nanoestruturado nas superfícies de implantes de titânio jateadas na formação do osso peri-implante na tíbia de coelhos. Os implantes jateados com Ca monstrou aumento significativo BIC (46,9\%) em comparação com os implantes de superfície jateada $(29,0 \%)$, relacionado à maior formação na área medular onde é pobre em tecido ósseo, sendo relatado também por outros autores (OONISHI et al., 1989; JANSEN et al. 1993a, 1993b). Mohammadi et al. (2003) histomorfometricamente avaliados quatro tipos diferentes de Ca-P implantes revestidos e um implante de titânio não revestido. Quatrocentos e oito implantes foram inseridos de forma aleatória, tanto na tíbia como no fêmur de 60 coelhos. 10 animais foram acompanhados por uma semana, 10 para 3 semanas e 40 por 6 semanas. A análise qualitativa e quantitativa indicaram que a resposta precoce (até 3 semanas) não era material específico no que diz respeito aos implantes testados, enquanto que às 6 semanas o grupo com revestimento de HA cristalina conseguia melhores escores de BIC tanto na tíbia como no fêmur dos coelhos em comparação com titânio não revestido.

Uma das principais causas de divergência quanto a efetividade do recobrimento das superfícies de titânio com fosfato de cálcio, se deve a forma como ela é realizada: eletrodeposição (MOHAMMADI et al., 2003), plasma-spray (JANSEN 
et al. 1993a), tratamento hidrotérmico (SUH et al., 2007). Segundo Gottlander et al.(1997) e Klein et al.(1994) a forma como a dissolução do revestimento é realizado podem influenciar negativamente na integração do implante.

Mais recentemente, os implantes revestidos com fosfato de cálcio têm chamado atenção quanto à capacidade incorporar drogas como os bifosfonado como revestimento terapêutico para ser liberado ao longo do tempo, localmente e de maneira controlada (CATTALINI et al., 2012; Jl et al., 2012). Com base nisto, os revestimentos de superfície de implantes são actualmente investigado como um promissor carreador para vários agentes terapêuticos, incluindo medicamentos antireabsorção do osso ou anabólico, como é geralmente usado para a osteoporose treatmento (CATTALINI et al., 2012, CAPRA et al., 2011; FORSGREN et al., 2011). 




\section{CONCLUSÃO}

No modelo utilizado o implante Y-TZP apresentou osseointegração similar ao titânio usinado e superior ao jateada com brushita, podendo ser considerado uma alternativa para substituir o implante titânio quando a estética esta envolvida. 




\section{REFERÊNCIAS}

Albrektsson T, Hansson HA, Ivarsson B. Interface analysis of titanium and zirconium bone implants. Biomaterials. 1985;6(2):97-101.

Amaral JMBL, Melhaço RDM, André LFM, Rossi, SB. Abutments de zircônia - uma nova era para a otimização estética em implantes dentários. Rev Catarin Implant. $2004 ; 6: 10-12$.

Andreiotelli M, Wenz HJ, Kohal R-J. Are ceramic implants a viable alternative to titanium implants? A systematic literature review. Clin. Oral Impl. Res. 20 (Suppl. 4), 2009; 32-47.

Antou G, Montavon G, Hlawka F, Cornet A, Coddet C. Microstructures of partially stabilized zirconia manufactured via hybrid plasma spray process. Ceramics International. 2005; 31(4): 611-619.

Assal PA. The osseointegration of zirconia dental implants. Schweiz Monatsschr Zahnmed. 2013;123(7-8):644-54. Review.

Azevedo VVC, Chaves AS, Bezerra DC, Costa ACFM. Materiais cerâmicos utilizados para implantes. Revista Eletrônica de Materiais e Processos. 2007; 2.3: 35-42.

Birkby I, Stevens R. Applications of zirconia ceramics. Key Eng Mater. 1996; $122-$ $124 ; 527-52$.

Bortz SA, Onesto EJ. Flame sprayed bioceramics. Cer Bull. 1973:52(12):898.

Bottino MC. Preparos dentais em próteses livre de metais. São Paulo: Artes Médicas; 2000:164-281.

Branemark PI, Zarb JA, Albrektsson T. Prótesis Tejido - Integradas. La Oseointegración em La Odontologia Clínica. California: Quintessence Books. 1987: 26-46.

Branemark PJ, Hansson BO, Adell R, Breine R, Lindstrom J, Ohlsson A. Intraosseous anchorage of dental prostheses. Experimental studies. Scand J Plast Reconstruction Surg. 1969; 3(2):81-100.

Brånemark R, Ohrnell LO, Skalak R, Carlsson L, Brånemark PI. Biomechanical characterization of osseointegration: an experimental in vivo investigation in the beagle dog. J Orthop Res. 1998;16(1):61-69. 
Bränemark R, Öjhmell LO, Nilsson P, Thornsen P. Biomechanical characterization of osseointegration during healing: an experimental in tivo study in the rat.

Biomaterials.1997;18:969-78.

Brånemark R, Skalak R. An in-vivo method for biomechanical characterization of bone-anchored implants. Med Eng Phys. 1998; 20(3):216-219.

Büchter A, Joos U, Wiesmann HP, Seper L, Meyer U. Biological and biomechanical evaluation of interface reaction at conical screw-type implants. Head Face Med. $2006 ; 21 ; 2(1): 5$.

Bukat A, Fassina P, Greco F, Piantelli. GSP-made Ca-PSZ for biomedical applications. In: Hulbert JE, Hulbert SF, Bioceramics. Terre Haute: Rose-Hulman Institute of Technology Publ.1990: 355-66.

Burger W, Boccalari M, Cittadini A, Piconi C, Richter HG, Ricci GA. Yttria stabilized zirconia (Y-TZP) for biomedical applications by an innovative approach. In: Ravaglioli A, editor. 4th Euro-Ceramics: Bioceramics. Faenza (Italy): 1995:29-36.

Burger W, Cittadini A, Bossi D, Boccalari M, Piconi C, Vat- teroni R. The relevance of zirconia purity in biomedical applications. In: Trans. 11th European Conf. on Biomaterials. Pisa, Italy, 1994:177-9.

Burger W, Richter HG, Piconi C, Cittadini A, Boccalari M, Vatteroni R. New TZP powders for medical grade zirconia. J Mat Sci Mater Med 1997;8:113-8

Callister Junior WD. Estruturas e propriedades das cerâmicas. In: Soares SMS, Miranda PEV editores. Ciência e Engenharia de Materiais: Uma introdução. 5a ed. São Paulo: LTC; 2002. Cap. 13.

Capra P, Dorati R, Colonna C, Bruni G, Pavanetto F, Genta I et al. A preliminary study on the morphological and release properties of hydroxyapatite-alendronate composite materials. J Microencapsul. 2011;28(5):395-405.

Carbonari M, Fredericci C, Mello RMD, Carvalho NTDA, Yoshimura HN. Abutments de ceramic de Y-TZP e compósito Al2O3-ZrO2/Mechanical performance of YTZP/AI2O3 ceramic abutments. ImplantNews. 2010;7(6):837-44.

Catelas I, Yahia LH, Huk O, Marchand R. Cytotoxicity of ceramic and polyethylene by flow cytometry. In: Trans. 4th World Biomaterials Congress. Toronto: Canada; 1996. p.11.

Cattalini JP, Boccaccini AR, Lucangioli S, Mouriño V. Bisphosphonate-based strategies for bone tissue engineering and orthopedic implants. Tissue Eng Part $B$ Rev. 2012;18(5):323-40. 
Chang YS, Oka M, Nakamura T, Gu HG. Bone remodelling around implanted ceramics. J Biomed Mat Res. 1996; 30:117-24.

Chevalier J, Cales B, Drouin JM. - Low Temperature Aging of Y-TZP Ceramic - J Am Ceram. 1999; 82: 2150-54.

Chevalier J, Deville S, Munch E, Jullian R, Lair F. Critical effect of cubic phase on aging in 3 mol\% yttria-stabilized zirconia ceramics for hip replacement prosthesis. Biomaterials. 2004;25:5539-45.

Chevalier J, Drouin JM, Cale's B. Low temperature ageing behaviour of zirconia hip joint heads. In: Sedel L, Rey C, editors. Bioceramics. Amsterdam, Elsevier, 1977: p.135-7.

Chevalier J, Gremillard L, Deville S. Degradation of Zirconia and Implications for Biomedical Implants. Annu Rev Mater Res. 2007;37:1-32.

Chevalier J. What future for zirconia as a biomaterial? Biomaterials. 2006;27(4): 53543.

Christel P, Meunier A, Dorlot JM, et al. Biomechanical compatibility and design of ceramic implants for orthopaedic surgery. Bioceramics: material charateristics versus in vivo behavior. Ann NY Acad Sci 1988;523:234-56.

Christel P. Zirconia: the second hip generation of ceramics for total hip replacement. Bull Hosp Joint Dis Orthop Inst. 1989;49(2):170-7.

Clark RJH, Bradley DC, Thornton P. The chemistry of titanium, zirconium and hafnium. Oxford: Pergamon; 1973.

Covacci V, Bruzzese N, Maccauro G Andreassi C, Ricci GA, Piconi C, et al. In vitro evaluation of the mutagenic and carcinogenetic power of high purity zirconia ceramics. Biomaterials. 1999;20:371-76.

Cumbrera FL, Sanchez-Bajo F, Fernandez R, Llanes L. Microstructure Effects in the X-ray powder diffraction profile of 9 mol\% Mg-PSZ. J Eur Ceram Soc, 1998;18:224752.

Curtis AR, Wright AJ, Fleming GJP. The influence of simulated masticatory loading regimes on the bi-axial flexure strength and reliability of a Y-TZP dental ceramic. $J$ Dent 2006;34:317-25.

De Aza AH, Chevalier J, Fantozzi G, Schehl M, Torrecillas R. Crack growth resistance of alumina, zirconia and zirconia toughened alumina ceramics for joint prostheses. Biomaterials. 2002;23(3):937-45. 
De Maeztu MA, Braceras I, Alava JI, Gay-Escoda C. Improvement of osseointegration of titanium dental implant surfaces modified with $\mathrm{CO}$ ions: a comparative histomorphometric study in beagle dogs. Int J Oral Maxillofac Surg. 2008; 37: 441-447.

De Mori R. Avaliação da interface implante/pilar protético antes e após carregamento cíclico. [dissertação] Taubaté: Universidade de Taubaté, Departamento de Odontologia; 2005.

Denry I, Kelly JR. State of the art of zirconia for dental applications. Dent Mater. 2008;24(3):299-307.

Depprich R, Ommerborn M, Zipprich $\mathrm{H}$, et al. Behavior of osteoblastic cells cultured on titanium and structured zirconia surfaces. Head Face Med. 2008b Dec 8;4:29.

Depprich R, Zipprich H, Ommerborn M, et al. Osseointegration of zirconia implants compared with titanium: an in vivo study. Head Face Med. 2008a Dec 11;4:30.

Depprich, R, Zipprich H, Ommerborn M, Mahn E, Lammers L, Handschel J, et al. Osseointegration of zirconia implants: an SEM observation of the bone-implant interface. Head Face Med. 2008, November;4:25.

Deville S, Chevalier J, Gremillard L. Influence of surface finish and residual stresses on the ageing sensitivity of biomedical grade zirconia. Biomaterials, 2006; $27: 2186-$ 92.

Deville S, Gremillard L, Chevalier J, Fantozzi G. A critical comparison of methods for the determination of the aging sensitivity in biomedical grade yttria-stabilized zirconia. J Biomed Mater Res B Appl Biomater. 2005;72(2): 239-45.

Dion I, Bordenave L, Lefebvre F et al. Physico-chemistry and cytotoxicity of ceramics, Part II. J Mater Sci Mater Med. 1994;5:18-24.

Dubruille JH, Viguier E, Le Naour G, Dubruille MT, Auriol M, Le Charpentier Y. Evaluation of combinations of titanium, zirconia, and alumina implants with 2 bone fillers in the dog. Int J Oral Maxillofac Implants. 1999;14(2):271-7.

Egeni GP, Jaksic M, Moschini G, Passi P, Piattelli A, Rossi, P, et al. PIXE and microPIXE studies of ion release around endosseous implants in animals. Nucl Instr Meth Phys Res B. 1996;109:289-293.

Elinson SV, Petrov KI. The Analytical Chemistry of Zirconium and Hafnium. Moscow: Izd. Nauka; 1965: 240. 
Embacher Filho A. Desenvolvimento de um implante osseointegrável: da teoria a prática. [tese de doutorado]. Araçatuba: Faculdade de Odontologia de Araçatuba (UNESP), 2003.

Esquivias L, Barrera-Solano C, Piñero M, Pietro C. Short-range order of yttria doped zirconia powders studied by X-ray absorption (II). J Alloys Compd. 1996; 239: 71-76.

Farnworth F, Jones SL, McAlpire I. The production, properties and sés of zirconum chemicals. V. K. Magnesium Elektron. Special publication. 1984.

Fontana F, Rocchietta I, Addis A, Schupbach P, Zanotti G, Simion M. Effects of a calcium phosphate coating on the osseointegration of endosseous implants in a rabbit model. Clin Oral Implants Res. 2011;22(7):760-6.

Forsgren J, Brohede U, Strømme M, Engqvist H. Co-loading of bisphosphonates and antibiotics to a biomimetic hydroxyapatite coating. Biotechnol Lett. 2011;33(6):12658.

Fujisawa A, Shimotoso T, Masuda S, Makinouchi K. The development of zirconia balls for THR with a high mechanichal strength, low phase transformation. In: Kokubo T, Nakamura T, Miyaji F, editors. Bioceramics 9. Amsterdam: Elsevier Science Publ., 1996:503-6.

Gahlert M, Roehling S, Sprecher CM, Kniha H, Milz S, Bormann K. In vivo performance of zirconia and titanium implants: a histomorphometric study in mini pig maxillae. Clin Oral Implants Res. 2012 Mar;23(3):281-6.

Gahlert M, Wieland SRM, Eichhorn S, Küchenhoff IH, Kniha H. A comparison study of the osseointegration of zirconia and titanium dental implants. A biomechanical evaluation in the maxilla of pigs. Clin Implant Dent Relat Res. 2010;12(4):297-305.

Garvie RC, Hannink RH, Pascoe RT. Ceramic steel? Nature. 1975;258:703-4.

Garvie RC, Nicholson PS. Structure and thermodynamical properties of partially stabilized zirconia in the CaO_ZrO_system. J Amer Ceram Soc. 1972;55:152-7.

Garvie RC, Urbani C, Kennedy DR, McNeuer JC. Biocompatibility of magnesia partially stabilized zirconia (MG-PSZ) ceramics. J Mater Sci. 1984;19:3224-8.

Gioka C, Bourauel C, Zinelis S, Eliades T, Silikas N, Eliades, G. Titanium orthodontic brackets: structure, composition, hardness and ionic release. Dent Mater. 2004; 20(7): 693-700.

Gottlander M, Johansson CB, Albrektsson T. Short- and long-term animal studies with a plasma-sprayed calcium phosphate-coated implant. Clin Oral Implants Res. 1997;8(5):345-51. 
Green DJ, Hannink RHJ, Swain MV. Transformation Toughening of Ceramics. Boca Raton, FL: CRC Press. 1989;232 pp.

Greenspan DC. Bioactive ceramic implante materials. Current Opinion in Solid State and Materials Science, 1999;4:389-393.

Guazzato M, Albakry M, Ringer SP, Swain MV. Strength, fracture toughness and microstructure of a selection of all-ceramic materials. Part I. Pressable and alumina glass-infiltrated ceramics. Dent Mater. 2004;.20(5) 441-448,.

Guazzato M, Albakry M, Ringer SP, Swain MV. Strength, fracture toughness and microstructure of a selection of all-ceramic materials. Part II. Zirconia-based dental ceramics. Dent Mater. 2004;20(5): 449-456.

Habibe AF, Santos C, Teixeira LHP, Maeda LD, Barboza JJR. Propriedades mecânicas de cerâmicas à base de zircônia sinterizadas com biovidro como aditivo de sinterização. Foz do Iguaçu: 17o CBECIMat - Congresso Brasileiro de Engenharia e Ciência dos Materiais; 2006.

Hahn RB. Zirconium and Hafnium. In: Kulthoff IM, Elving P. Treatise on analytical chemistry. Part II, 5, Analytical Chemistry of the elements. New York: Interscience; 1961. p. 61-138.

Hannink RHJ, Kelly PM, Muddle BC. Transformation toughening in Zirconia Containing Ceramics. J Am Ceramic Soc. 2000;83(83):461-87.

Harmand M-F, Naji A, Lorini G, Priem Th, Piconi C. Cytotoxicity study of ceramic powders for plasma spray coating. In: Proc. 12th ESB Conf. on Biomaterials. Oporto, Portugal, Sept. 1995:141.

Hatch JP, Shinkai RS, Sakai S, Rugh JD, Paunovich ED. Determinants of masticatory performance in dentate adults. Arch Oral Biol. 2001;46(7):641-8.

Hatley CL, Cameron SM, Cuenin MF, Parker MH, Thompson SH, Harvey SB. The Effect of Dental Implant Spacing on Peri-implant Bone Using the Rabbit (Oryctolagus cuniculus) Tibia Model. J Prosth. 2001; 10:154-159.

Helmer JD, Driskell TD. Research on bioceramics. Symp. on Use of Ceramics as Surgical Implants. South Carolina (USA): Clemson University, 1969.

Heydecke G, Kohal R, Gläser R. Optimal esthetics in singletooth replacement with the re- implant system: a case report. Int J Prosthodont. 1999; 12:184-189.

Hoffmann O, Angelov N, Gallez F, Jung RE, Weber FE. The zirconia implant-bone interface: a preliminary histologic evaluation in rabbits. Int $\mathrm{J}$ Oral Maxillofac Implants. 2008 Jul-Aug;23(4):691-5. 
Hulbert SF, Morrison SJ, Klavitter JJ. Tissue reaction to three ceramics of porous and non-porous structures. J Biomed Mater Res. 1972:6:347-74.

Ichikawa Y, Alkagawa Y, Nikai H, Tsuru H. Tissue compatibility and stability of a new zirconia ceramic in vivo. J Prostet Dent. 1992;68:322-6.

Ishikawa-Nagai S, Da Silva JD, Weber HP, Park SE. Optical phenomenon of periimplant soft tissue. Part II. Preferred implant neck color to improve soft tissue esthetics. Clin. Oral Impl Res. 2007;18(5):575-580.

Ito A, Tateishi T, Niwa S, Tange S. In vitro evaluation of the cytocompatibility of wear particles generated by UHMWPE- zirconia friction Clin Mat. 1993; 12:203-9.

Jansen JA, van der Waerden JP, Wolke JG. Histologic investigation of the biologic behavior of different hydroxyapatite plasma-sprayed coatings in rabbits. J Biomed Mater Res. 1993;27(5):603-10.

Jansen JA, Wolke JG, Swann S, Van der Waerden JP, de Groot K. Application of magnetron sputtering for producing ceramic coatings on implant materials. Clin Oral Implants Res. 1993;4(1):28-34.

Ji W, Wang H, van den Beucken JJ, Yang F, Walboomers XF, Leeuwenburgh S et al. Local delivery of small and large biomolecules in craniomaxillofacial bone. Adv Drug Deliv Rev. 2012;64(12):1152-64.

Jung BA, Yildizhan F, Wehrbein $\mathrm{H}$. Bone-to-implant contact of orthodontic implants in humans - a histomorphometric investigation. Eur Journal of Orthod. 2008; 30:552557.

Kelly Jr, Denry I, Stabilized zirconia as a structural ceramic: An overview. Dent Mater. 2008; 24(3):289-98.

Kelly JR, Nishimura I, Campbell SD. Ceramics in dentistry: historical roots and current perspectives. J Prosthet Dent. 1996; 75(3):18-32.

Kelly JR, Tesk JA, Sorensen JA. Failure of all-ceramic fixed partial dentures in vitro and in vivo: analysis and modeling. J Dent Res. 1995; 74(6):1253-8.

Klein CP, Wolke JG, de Blieck-Hogervorst JM, de Groot K. Calcium phosphate plasma-sprayed coatings and their stability: an in vivo study. J Biomed Mater Res. $1994 ; 28(8): 909-17$.

Kohal RJ, Att W, Bächle M, Butz F. Ceramic abutments and ceramic oral implants. An update. Periodontol 2000. 2008; 47: 224-43. 
Kohal RJ, Weng D, Bächle M, Strub JR. Loaded custom-made zirconia and titanium implants show similar osseointegration: an animal experiment. J Periodontol. 2004; 75:1262-68.

Kohal RJ, Wolkewitz M, Hinze M, Han JS, Bächle M, Butz F. Biomechanical and histological behavior of zirconia implants: an experiment in the rat. Clin Oral Implants Res. 2009; 20(4):333-9.

Kohorst P, Borchers L, Strempel J, Stiesch M, Hassel T, Bach FW et al. Lowtemperature degradation of different zirconia ceramics for dental applications. Acta Biomater. 2012; 8(3):1213-20.

König Jr B, Lopes CC. Bone remodeling analysis after placement of dental implants using polifluorochrome sequential labeling. Annals of Anatomy, 2002;v.184,p241244.

Koo S, Konig Júnior B, Mizusaki Cl, Allegrini Júnior S, Yoshimoto M, Carbonari MJ. Effects of alcohol consumption on osseointegration of titanium implants in rabbits. Implant Dent. 2004; 13: 232-237.

Kosmac T, Oblak C, Jevnikar P, Funduk N, Mariom L. Strength and reliability of surface treated Y-TZP dental ceramics. J Biomed Mater Res. 2000; 53:304-313.

Kulkov SN. The structure transformations in nanocrystralline zircônia. Nuclear instruments and methods. Phys Res. 2007; 37:23.

Kumar P, Shimizu J, Oka M, Kotoura Y, Nakamura T, Yamamuro T, et al. Biological reaction of zirconia ceramics. In: Oonishi $\mathrm{H}$, Aoki $\mathrm{H}$, Sawai K, editors. Bioceramics 1. Brentwood (Missouri, USA): Ishiyaku EuroAmerica Inc. Publ., 1989:341-6.

Lancaster JG, Dowson D, Fisher J. The Influence of femoral material manufacturing technique and surface topography on the wear of UHMWPE in total hip joint replacement. In: Trans. 5th World Biomaterials Congress. Toronto, Canada, 1996:581.

Langhoff JD, Voelter K, Scharnweber D, et al. Comparison of chemically and pharmaceutically modified titanium and zirconia implant surfaces in dentistry: a study in sheep. Int J Oral Maxillofac Surg. 2008 Dec;37(12):1125-32.

Lawn BR, Deng Y, Thompson VP. Use of contact testing in the characterization and design of all-ceramic crownlike layer structures: a review. J Prosthet Dent. $2001 ; 86(5): 495-510$.

Lawson S. Environmental degradation of zirconia ceramics. J Eur Ceram Soc. 1995;15:485-502. 
Lawson S. Environmental degradation of zirconia ceramics. J Eur Ceram Soc. $1995 ; 15(6): 485-502$.

Leach CA. Sintering of magnesium partially stabilized zirconia - behaviour of an impurity silicate phase. Mater Sci Technol. 1987;3:321-4.

Lepistö, T, Mäntylä, TA. Degradation of TZP ceramics in humid atmospheres. In: Clarke DE, Zoitos BK, editors. Corrosion of glass, ceramics, and ceramic superconductors. Park Ridge (New Jersey, USA): Noyes Publication Publ., 1992;492-513.

Li J, Liu Y, Hermansson L, Söremark R. Evaluation of biocompatibility of various ceramic powders with human fibroblasts in vitro. Clin Mat 1993;12:197-201.

Li J, Zheng Q, Hashida T. Degradation of yttria-stabilized zirconia at $370 \mathrm{~K}$ under a low applied stress. Mater Sci Eng A. 2001;297:26-30.

Lin YJ, Angelini P, Mecartney ML. Microstructural and chemical influences of silicate grain boundary phases in yttria stabilized zirconia. J Amer Ceram Soc. 1990;73:2728-35.

Liu P, Yao YN, Wu SD, Dong HJ, Feng GC, Yuan XY. The efficacy of deferiprone on tissues aluminum removal and copper, zinc, manganese level in rabbits. J Inorg Biochem. 2005; 99(8):1733-1737.

Lourenço EJV. Avaliação da osteogênese com proteínas ósseas morfogenéticas (BMPs): análise em defeitos na calvária e ao redor de implantes de titânio em coelhos [tese]. Bauru (SP): Faculdade de Odontologia de Bauru, Universidade de São Paulo;2002.

Lughi V, Sergo V. Low temperature degradation -aging- of zirconia: A critical review of the relevant aspects in dentistry. Dental Mater. 2010;26:807-20.

Luthy H, Filser F, Loeffel O, Schumacher M, Gauckler LJ, Hammerle CH. Strength and reliability of four-unit all-ceramic posterior bridges. Dent Mater. 2005;21(10):93037.

Maccauro G, Specchia N, Arena M, Piconi C, Greco F. Biological response to calcia partially stabilized zirconia ceramics. In: Proc. 8th ESB Meeting. Roma, Italia, June 1992:110.

Maetzu MA, Alava JI, Gay-Escoda C. Ion implantation: surface treatment for improving the bone integration of titanium and Ti6Al4V dental implants. Clin Oral Impl Res. 2003;14(1): 57-62. 
McLaren EA, White SN. Glass Infiltred Zirconia / Alumina - based ceramic for crowns and fixed partial dentures. Pract Periodont Asthetic Dent. 1999;11(8):985-94.

Medevielle A, Thevenot F, Theheux D. Wear resistance of zircônias. Dielectrical approach. Wear. 1997;213:13-30.

Mielczarek A, Fischer H, Riehemann W. Amplitude-dependent damping of PSZ with sinter defects. Mat Sci Eng A-Struct. 2006;442:488-91.

Miyashiro M, Suedan V, Moretti Neto RT, Ferreira PM, Rubo JH. Validation of an experimental polyurethane model for biomechanical studies on implant supported prosthesis - tension tests. J Appl Oral Sci. 2011;19(3):244-8.

Mohammadi S, Esposito M, Hall J, Emanuelsson L, Krozer A, Thomsen P. Shortterm bone response to titanium implants coated with thin radiofrequent magnetronsputtered hydroxyapatite in rabbits. Clin Implant Dent Relat Res. 2003;5(4):241-53.

Möller B, Terheyden H, Açil Y, Purcz NM, Hertrampf K, Tabakov A et al. A comparison of biocompatibility and osseointegration of ceramic and titanium implants: an in vivo and in vitro study. Int J Oral Maxillofac Surg. 2012;41(5):638-45.

Moretti Neto RT, Hiramatsu DA, Suedam V, Conti PCR, Rubo JH. Validation of an experimental polyurethane model for biomechanical studies on implant-supported prosthesis - compression tests. J Appl Oral Sci. 2011;19(1):47-51.

Nishikawa T, Masuno K, Mori M, Tajime Y, Kakudo K, Tanaka A. Calcification at the interface between titanium implants and bone: Observation with confocal laser scanning microscopy. J Oral Implan. 2006; XXXII:211-217.

Oka M, Kumar P, Ikeuchi K, Yamamuro T, Nakamura T. Low wear rate of UHMWPE against zirconia. In: Yamamuro T, Kokubo T, Nakamura T, editors. Bioceramics 5. Kyoto (Japan), 1992:373-9.

Oliva J, Oliva X, Oliva D. Five-year success rate of 831 consecutively placed Zirconia dental implants in humans: a comparison of three different rough surfaces. Int J Oral Maxillofac Implants. 2010;25(2):336-344.

Oonishi H, Yamamoto M, Ishimaru H, Tsuji E, Kushitani S, Aono M et al. The effect of hydroxyapatite coating on bone growth into porous titanium alloy implants. J Bone Joint Surg Br. 1989;71(2):213-6.

Özkurt Z, Kazazoğlu E. Zirconia dental implants: a literature review. J Oral Implantol. 2011 Jun;37(3):367-76. 
Papanagiotou HP, Morgano SM, Giordano RA, Pober R. In vitro evaluation of lowtemperature aging effects and finishing procedures on the flexural strength and structural stability of Y-TZP dental ceramics. J Prosthet Dent. 2006;96(3):154-64.

Park SE, Da Silva JD, Weber HP, Ishikawa-Nagai S. Optical phenomenon of periimplant soft tissue. Part I. Spectrophotometric assessment of natural tooth gingiva and peri-implant mucosa. Clin Oral Impl Res. 2007;18:569-574.

Park YS, Chung SH, Shon WJ. Peri-implant bone formation and surface characteristics of rough surface zirconia implants manufactured by powder injection molding technique in rabbit tibiae. Clin Oral Implants Res. 2013;24(5):586-91.

Pastor FP, Bellini DH, Lenharo A. Otimização da estética - uso de abutment de zircônia e coroa all-ceram: relato de caso clínico. Innovat J. 2004;17-21.

Pellizzer EP, Muench A. Forças de mordida relacionadas a próteses parciais removíveis inferiores. Rev Odontol Univ São Paulo.1998;12(4):401-7.

Piantelli S, Maccauro G, Specchia N, Maggiano N, Piconi C, Greco F. Effects of ceramic precursors on human lymphocyte mitogenesis. In: 4th World Biomaterials Congress Transactions. Berlin, Germania, 24-28 April 1992:343.

Piconi C, Maccauro G. Zirconia as a ceramic biomaterial. Biomaterials. 1999; 20(1):1-25.

Pizolato RA, Gavião MBD, Berretin-Felix G, Sampaio ACM, Trindade Junior AS. Maximal bite force in young adults with temporomandibular disorders and bruxism. Braz Oral Res. 2007;21(3):278-83.

Poulos NM, Rodriguez NA, Lee J, Rueggeberg FA, Schüpbach P, Hall J, et al. Evaluation of a Novel Calcium Phosphate-Coated Titanium Porous Oxide Implant Surface: A Study in Rabbits. . Int J Oral Maxillofac Implants 2011;17:793-98.

Purchio RA, Zavaglia CAC, Consolaro A. Zirconia biocompatibility for femoral hip prosthesis. In: Ravaglioli A, editor. 4th Euro Ceramics, vol. 8-Bioceramics. Faenza, Italy, Faenza, 1995:313-8.

Quan R, Yang D, Wu X, Wang H, Miao X, Li W. In vitro and in vivo biocompatibility of graded hydroxyapatite-zirconia composite bioceramic. J Mater Sci Mater Med. 2008;19:183-187.

Radin E, Rose RM. Role of subchondral bone in the initiation and progression of cartilage damage. Clin Orthop. 1986;213:34-40. 
Rahmani M, Shimada E, Rokni S, Deporter DA, Adegbembo AO, Valiquette N, et al. Osteotome sinus elevation and simultaneous placement of porous-surfaced dental implants: a morphometric study in rabbits. Clin. Oral Impl Res. 2005;16(6):692-699.

Rahn BA, Perren SM. Alizarin complexon-fluorochrome for bone and dentine labeling. Experimentia, 1972; v15, p180.

Raigrodski AJ. Contemporary materials and technologies for all-ceramic fixed partial dentures: a review of the literature. J Prosthet Dent. 2004;92(6):557-62.

Rashad MM, Baioumy HM. Effect of thermal treatment on the crystal structure and morphology of zircon nanopowders produced three different routes. J Mat Proc Tech. 2008;195(1):178-185.

Reed JL, Lejus AM. Effect of grinding and polishing on near surface phase transformations in zirconia. Mat Res Bull. 1977;12:949-54.

Regish KM, Sharma D, Prithviraj DR. An overview of immediate root analogue zirconia implants. J Oral Implantol. 2013 Apr;39(2):225-33.

Richerson DW. Modern ceramic Engineering: properties, processing, and use in design. New York: Marcel Dekker. 1992.

Richter HG, Burger W, Osthues F. Zirconia for medical implants-the role of strength properties. In: Andersson OH, Yli- Urpo A, editors. Bioceramics 7. London: Butterworth- Heinemann Publ, 1994:401-6.

Rimondini L, Cerroni L, Carrassi A, Torricelli P. Bacterial colonization of zirconia ceramic surfaces: An in vitro and in vivo study. Int J Oral Maxillofac Implants 2002;17:793-98.

Roberts WE, Nelson CL, Goodacre CJ. Rigid implant anchorage to close a mandibular first molar extraction site. J Clin Orthod. 1994;28(12)693- 704.

Roberts WE, Smith RK, Zilberman Y, Mozsary PG, Smith RS. Osseous adaptation to continuous loading of rigid endosseous implants. Am J Orthod. 1984;86(2):95- 111.

Roy P, Bertrand G, Coddet C. Spray drying and sintering of zirconia based hollow powders. Powder Technology. 2005;157(1):20-26.

Ruff O, Ebert F, Stephen E. Contributions to the ceramics of highly refractory materials: II. System zirconia-lime. Z Anorg Allg Chem. 1929;180(1):215-24.

Rühle $\mathrm{M}$, Claussen N, Heuer $\mathrm{AH}$. Microstructural studies of $\mathrm{Y}_{-} \mathrm{O}_{-}$-containing tetragonal ZrO_polycrystals (Y-TZP). In: Claussen N, Ru“hle M, Heuer AH, editors. 
Advances in ceramics, vol. 12. Science and Technology of Zirconia II. Columbus (OH, USA): American Ceramic Society, 1984:352-70.

Ruiz L, Readey MJ. Effect of heat treatment on grain size, phase assemblage, and mechanical properties of 3 mol\% YTZP. J Am Ceram Soc. 1996;79(9):2331-40.

Sato T, Shimada M. Control of the tetragonal-to-monoclinic phase transformation of yttria partially stabilized zirconia in hot water. J Mater Sci 1985;20:3899-992.

Sato T, Shimada M. Transformation of yttria-doped tetragonal ZrO polycrystals by annealing in water. J Amer Ceram Soc 1985;68(6):356-9.

Satoh Y, Niwa S. Tissue-biomaterial interface characteristics of zirconia ceramics, In: Hulbert JE, Hulbert SF, editors. Bio- ceramics 3. Terre Haute (Indiana, USA): RoseHulman Institute of Technology Publ., 1990:101-8.

Scarano A, Piattelli M, Caputi S, Favero GA, Piattelli A. Bacterial adhesion on commercially pure titanium and zirconium oxide disks: An in vivo human study. $J$ Periodontol 2004;75: 292-96.

Scardi P, Leoni M, Bertini L, Bertamini, L. Residual stress in partially-stabilisedzirconia TBCs: experimental measurement and modeling. Surface and Coatings Technology. 1997;94:82-88.

Schacht M, Boukis N, Dinjus E, Ebert K, Janssen R, Meschke F, et al. Corrosion of zirconia ceramics in acidic solutions at high pressures and temperatures. J Eur Ceram Soc. 1998;18(16):2373-2376.

Schubert H, Frey F. Stability of Y-TZP during hydrothermal treatment: neutron experiments and stability considerations. J Eur Ceram Soc. 2005;25:1597-602.

Schubert H, Frey F. Stability of Y-TZP during hydrothermal treatment: neutron experiments and stability considerations. J Eur Ceram Soc. 2005;25:1597-602.

Schwartz GL. Wear and strength of zirconia and alumina ceramic materials. 38th ORS. New Orleans, Louisiana, USA, 1990:483.

Schwarz F, Herten M, Ferrari D, Wieland M, Schmitz L, Engelhardt E, et al. Guided bone regeneration at dehiscence-type defects using biphasic hydroxyapatite + beta tricalcium phosphate (Bone Ceramic1) or a collagen-coated natural bone mineral (BioOss Collagen1): an immunohistochemical study in dogs. Int J Oral Maxillofac. Surg. 2007;36(12):1198-1206.

Sennerby L, Dasmah A, Larsson B, Iverhed M. Bone tissue responses to surfacemodified zirconia implants: a histomorphometric and removal torque study in the rabbit. Clin Impl Dent Relat Res. 2005;7 Suppl 1:S13-20. 
Serson D. Implantes orais: teoria e prática. Porto Alegre: Artes Médicas, 1985:4-5.

Setzer B, Bächle M, Metzger M C, Kohal R J: The gene-expression and phenotypic response of hFOB 1.19 osteoblasts to surface-modified titanium and zirconia. Biomaterials 30: 979-990 (2009)

Shimizu K, Oka M, Kumar P, Kotoura Y, Yamamuro T, Makinouchi K, et al. Timedependent changes in the mechanical properties of zirconia ceramic. J Biomed Mat Res. 1993;27:729-34.

Shin D, Blanchard SB, Ito M, Chu TM. Peripheral quantitative computer tomographic, histomorphometric, and removal torque analyses of two different non-coated implants in a rabbit model. Clin Oral Implants Res. 2011;22(3):242-50.

Specchia N, Sabetta SP, Greco F. Quantitative analysis of the bone healing process around ceramic implants (CaPSZ, titania dioxide). In: Proc. II EFORT Congress. Munich, Germany,1999; 273.

Stanford, MC. Surface modification of biomedical and dental implants and the processes of inflammation, wound healing and bone formation. Int. J. Mol. Sci. 2010, 11, 354-369.

Stevens R. Engineering properties of zirconia. In: Engineered Materials Handbook, Vol. 4, Ceramics and Glasses. Ed. S.J. Schneider, Jr., ASM International, 1991:77586.

Stevens R. Zirconia and zirconia ceramics. 2nd ed., United Kington, Magnesium Electron Publication. 1986.

Straumann [homepage na internet]. Acesso em: 27/03/2011. Disponível em: http://www.straumann.com.

Subbarao EC. Zirconia - an overview. In: Science and Technology of Zirconia, Advances in Ceramics, v.3, eds. A.H. Heuer, L.W. Hobbs. J Am Ceram Soc. 1981:124.

Suh JY, Jeung OC, Choi BJ, Park JW. Effects of a novel calcium titanate coating on the osseointegration of blasted endosseous implants in rabbit tibiae. Clin Oral Implants Res. 2007;18(3):362-9.

Sundh A, Sjögren G. Fracture resistance of all-ceramic zirconia bridges with differing phase stabilizers and quality of sintering. Dent Mater. 2006;22(8):778-784.

Suzuki K, Aoki K, Ohya K. Effects of surface roughness of titanium implants on bone remodeling activity of femur in rabbits. Bone. 1997;21:507-514. 
Swab JJ. Low temperature degradation of Y-TZP materials. J Mater Sci. $1991 ; 26: 6706-14$.

Tateishi T, Ushida T, Aoki H, Ikada Y, Nakamura M, Williams DF, et al. Round-robin test for standardization of biocompatibility test procedures by cell culture method. In: Doherty, PJ, Williams RL, Williams, DF, Lee AJC, editors. Biomaterials-Tissue Interfaces. Advances in Biomaterials (2nd edn.), Vol. 10, Elsevier, Amsterdam. 1992:89-97.

Therheyden H, Jepsen S, Möller B, Tucker MM, Rueger DC. Sinus floor augmentation with simultaneous placement of dental implants using a combination of deproteinized bone xenografts and recombinant human osteogenic protein-1. A histometric study in miniature pigs. Clin Oral Implant Res. 1999;10:510-521.

Theunissen GSAM, Bouma JS, Winnbust AJA, Burggraaf AJ. Mechanichal properties of ultra-fine grained zirconia ceramics. J Mater Sci. 1992;27:4429-38.

Thomsen P, Larsson C, Ericson LE, Sennerby L, Lausmaa J, Kasemo B. Structure of the interface between rabbit cortical bone and implants of gold, zirconium and titanium. J Mater Sci Mater Med. 1997;8(11):653-65

Tinschert J, Zwez D, Marx R, Anusavice KJ. Structural reliability of alumina-, feldspar-, leucite-, mica- and zirconia-based ceramics. J Dent. 2000;28(7):529-35.

Usui, T, Uematsu S, Kanegae H, Morimoto T, Kurihara S. Change in maximum occlusal force in association with maxillofacial growth. Orthod Craniofac Res. 2007;10(4):226-34.

Vagkopoulou T, Koutayas SO, Koidis P, Strub JR. Zirconia in Dentistry: Part 1. Discovering the nature of an upcoming bioceramic. Eur J Esthet Dent. 2009;4(2):130151.

Vena P, Gastaldi D, Contro R, Petrini L. Finite element analysis of the fatigue crack growth rate in transformation toughening ceramics. Int J Plast. 2006;22(5):895-920.

Wagner W. Histologic bone reactions after implantation of alumina and zirconia pins. Trans. 7th European Conf. on Biomaterials. Amsterdam, 1987:44.

Wataha, JC. Materials for endosseous dental implants. J Oral Rehabil. 1996;23(2):79-90.

Wei WC, Lin YP. Processing character of MgO-partially stabilized zirconia (PSZ) in size grading prepared by infection molding. J Eur Ceramic Soc. 1998;18(14):210716.

Wenz HJ, Bartsch J, Wolfart S, Kern M. Osseointegration and clinical success of 
zirconia dental implants: A systematic review. Int J Prosthodont. 2008; 21(1):27-36.

Wiltfang, et al. Zahnimplantate aus Keramik (Zirkonoxid-Keramikimplantate). Acesso em: 27/12/2010. Disponível em <http://www.implantate.com>.

Woodman JL, Jacobs JJ, Galante JO, Urban RM, et al. Metal ion release from titanium-based prosthetic segmental replacements of long bones in baboons: a longterm study. J Orthop Res. 1984b;1(4):421-430.

World Health Organization [homepage na internet]. Geneva; c2004 [atualizado em 21 set 2004; acesso em 22 set 2004]. Disponível em: http://www.who.int/

Yoshida T, Hoshina T, Mkaizawa I, Sakurada S. Properties of partially stabilized zirconia fuel cell. J Electrochem Soc. 1989;136(9):2604-6.

Yoshimoto M, König B Jr, Allegrini S Jr, de Carvalho Lopes C, Carbonari MJ, Liberti $E A$, et al. Bone healing after the inferior alveolar nerve lateralization: A histologic study in rabbits (Oryctolagus cuniculus). J Oral Maxillofac Surg. 2004;62 (9 Suppl 2):131-135.

Yoshimura M, Noma T, Kawabata K, Somiya S. Role of $\mathrm{H}_{2} \mathrm{O}$ on the degradation process of Y-TZP. J Mater Sci Lett 1987;6:465.

You TM, Choi BH, Li J, Jung JH, Lee HJ, Lee SH, et al. The effect of platelet-rich plasma on bone healing around implants placed in bone defects treated with BioOss: a pilot study in the dog tibia. Oral Surg Oral Med Oral Pathol Oral Radiol Endod. 2007;103(4):e8-12.

Zembic A, Sailer I, Jung RE, Hämmerle CH. Randomized-controlled clinical trial of customized zirconia and titanium implant abutments for single-tooth implants in canine and posterior regions: 3-year results. Clin Oral Impl Res. 2009;20(8)802-8. 



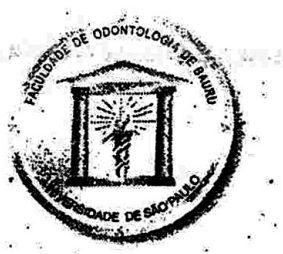

\section{Universidade de São Paulo Faculdade de Odontologia de Bauru}

Al. Dr. Oćtávio Pinheiro Brisolla, 9-75 - Bauru-SP - CEP 17012-901 - C.P. 73

PABX (0XX14)3235-8000-FAX (0XX14)3223-4679

Comissão de Étíca no Ensino e Peșuisa em Animaís

Fone: (14)3235-8356

,e-mail: mferrari@fob.usp.br

CEEPA-PROC. NNo 006 /2010,

Bauru, 5 de maio de 2010.

Senhor Professor,

O projeto de pesquisa encaminhado a esta Cómissão. de Ética no Ensino e Pẽsquisa em Animais, denominado "Implantes de cerâmica de Y-TZP e Compósito de $\mathrm{Al}_{2} \mathrm{O}_{3}-\mathrm{ZrO}_{2}$. Avaliação Morfomética”, de autoria de Renato Martins, foi enviado ao, relator para avaliação.

O parecer do Relator aprovando o projeto foi aceitọ em reunião desta Comissão realizada no dia 4 de maio de 2010, considerando que não haver impedimentos éticos.

Atenciosamente,

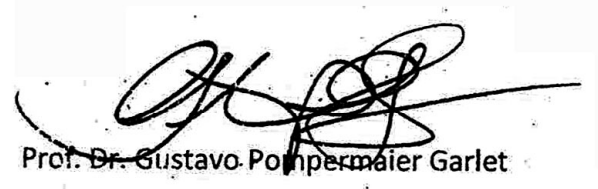

Presidente da Comissão de Ética no Ensino e Pesquiisa em Animais

Prof. Dr. Rodrigo Cardoso de Oliveira

Docente dó Départamento de Ciências Biológicas 